\title{
MODELAGEM DO MICROCLIMA EM CASA-DE-VEGETAÇÃO
}

\section{ROBERTO TERUMI ATARASSI}

Engenheiro Agrônomo

Orientador: Prof. Dr ROGÉRIO TEIXEIRA DE FARIA

Dissertação apresentada à Escola Superior de Agricultura "Luiz de Queiroz", Universidade de São Paulo, para obtenção do título de Mestre em Agronomia, Área de Concentração: Irrigação e Drenagem.

PIRACICABA

Estado de São Paulo

Maio - 2000 


\section{ERRATA}

ATARASSI, ROBERTO TERUMI. Modelagem do microclima em casa-de-vegetação.

Na página 52, Tabela 1, onde se lê " 102,2 e 104,0" para Umidades relativas máximas, leia-se 100 para ambas

Na página 54, Tabela 3 , linha 11 , onde se lê "W.K.1n leia-se "W. $\mathrm{m}^{-2} \cdot K^{1 \mathrm{n}}$

Na página 56 , Tabela 4, linha 10 , onde se lê "W.K. ${ }^{-1 n}$ leia-se "W. $\mathrm{m}^{-2} \cdot K^{-1 n}$

Na página 70 , linha 5 , onde se lê "...massa (LRe e $\left.P a b, \tau_{O L}\right)$ e a temperatura do ar interna $(K, T e) \ldots$ " leia-se "...massa (URe e Pab) e a temperatura do ar interna $\left(K\right.$, Te e $\left.\tau_{O L}\right) \ldots$..

Na página 73, Tabela 9, nas linha 5 e 9 , referente aos dados de " $G$ ", não considerar os valores tabulados (Erro médio, Desvio padrão do erro, Coef. angular e $R^{2}$ ), tanto para a condição de "Casa-de-vegetação com cortinas fechadas" quanto para "Casa-de-vegetação com cortinas abertas" $^{n}$

Na página 76, Figura 18, referente aos gráficos de "Rn - medido $\times$ simulado" tanto para "Estufa fechada" como para "Estufa aberta", não considerar a regressão para "Reta 1:1" e seus valores de $R^{2}$ 
Dados Internacionais de Catalogação na Publicação (CIP) DIVISÃO DE BIBLIOTECA E DOCUMENTAÇÃO - Campus "Luiz de Queiroz"/USP

\author{
Atarassi, Roberto Terumi \\ Modelagem do microclima em casa-de-vegetação / Roberto Terumi Atarassi. - - \\ Piracicaba, 2000. \\ 96 p. : il. \\ Dissertação (mestrado) - - Escola Superior de Agricultura Luiz de Queiroz, 2000. \\ Bibliografia. \\ 1. Balanço de energia 2. Estufa 3. Meteorologia agrícola 4. Microclima 5. Modelo \\ matemático 6 . Temperatura 7 . Umidade relativa do ar I. Titulo
}

CDD 630.2515 
Aos meus pais, que sempre me acompanharam na minha caminhada para o que eu sou hoje, dedico este trabalho 


\section{AGRADECIMENTOS}

Ao Prof. Dr. Rogério Teixeira de Faria, pela orientação e apoio para o desenvolvimento deste trabalho.

Ao Prof. Dr. Marcos Vinicius Folegatti, pela orientação, incentivo e amizade.

Aos colegas do Curso de Pós-graduação em Irrigação e Drenagem, pela colaboração no trabalho e pela grande amizade.

Ao Prof. Quirijn de Jong Van Lier, do Departamento de Ciências Exatas da ESALQ, pelas idéias e sugestões.

À Luciana Bianchini, pelos conselhos e amizade incondicional.

A Adriano Dal Bosco pelas sugestões e correção do material.

A todas as pessoas que, direta ou indiretamente, contribuíram para realização deste trabalho. 


\section{SUMÁRIO}

Página

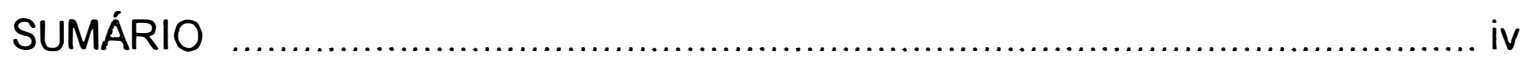

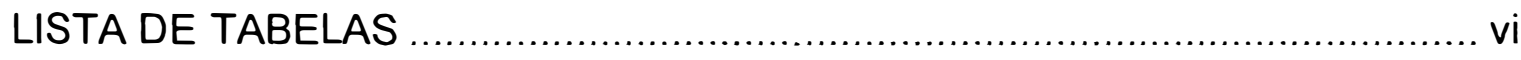

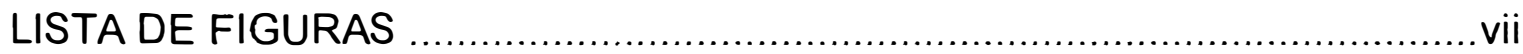

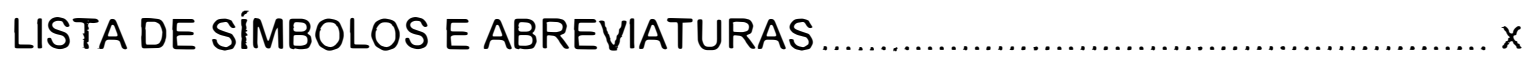

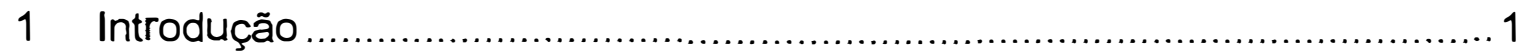

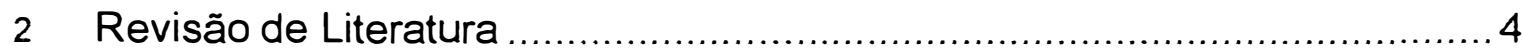

2.1 Cultivo em Casas-de-vegetação ..................................................... 4

2.2 Microclima no Interior de Casas-de-vegetação ................................... 6

2.2.1 Radiação Solar em Casas-de-vegetação ........................................... 6

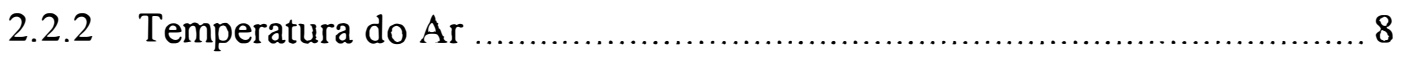

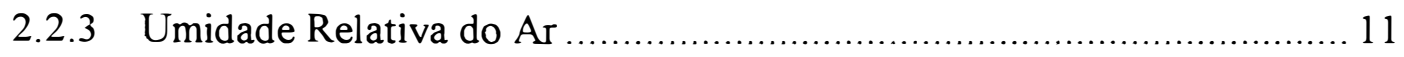

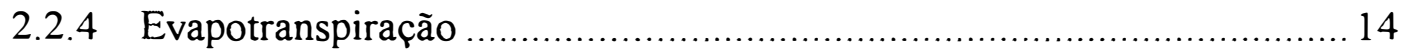

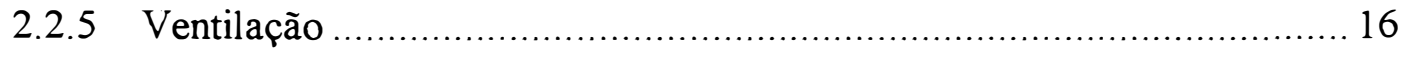

2.3 Modelagem em casas-de-vegetação ........................................... 18

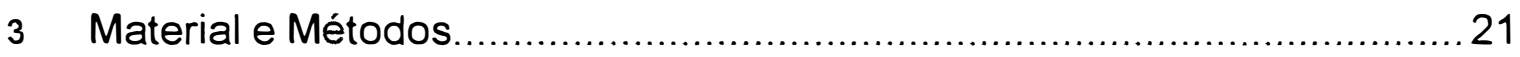

3.1 Desenvolvimento do modelo ESTUFA .................................... 21

3.1.1 Transmissão da radiação através da cobertura .................................... 22

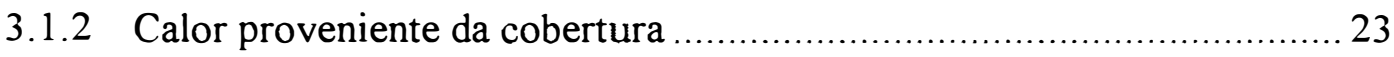

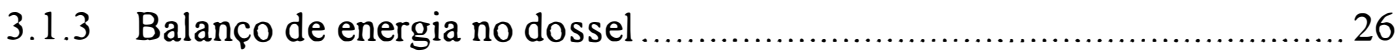

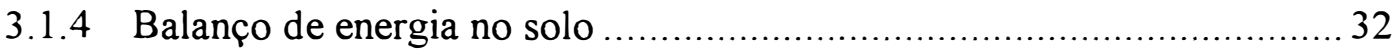

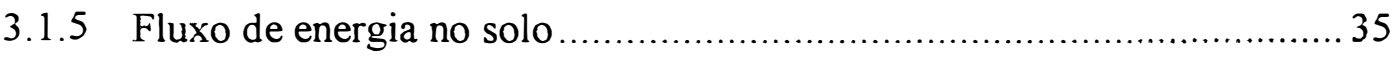


3.1.6 Perda de calor através da cobertura plástica. ....................................... 37

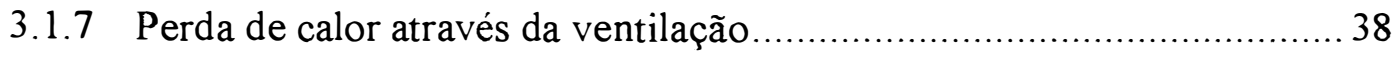

3.1.8 Energia disponivel para o aquecimento do ar ...................................40

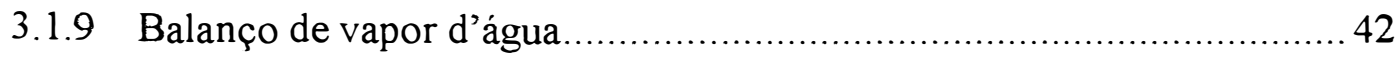

3.1.10 Volume e área de cobertura da casa-de-vegetação................................. 43

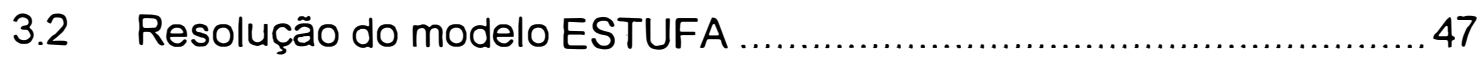

3.3 Comportamento geral do modelo ESTUFA ...................................51

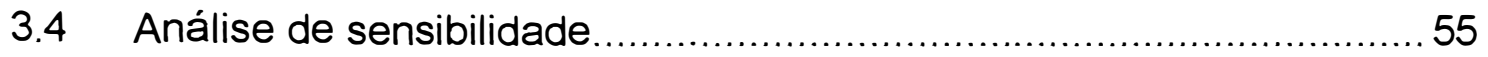

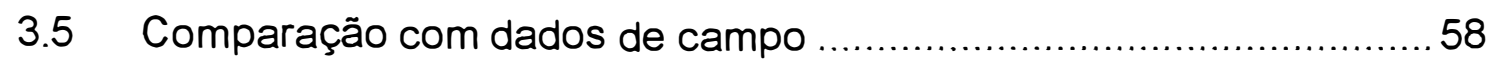

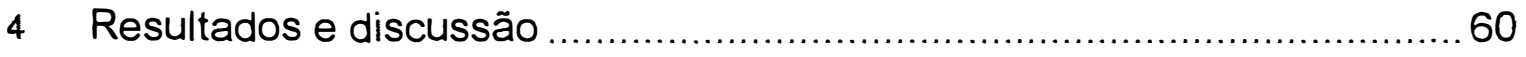

4.1 Comportamento do modelo ESTUFA .....................................6 60

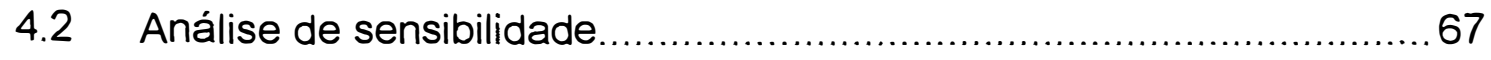

4.3 Comparação com dados de campo ...........................................71

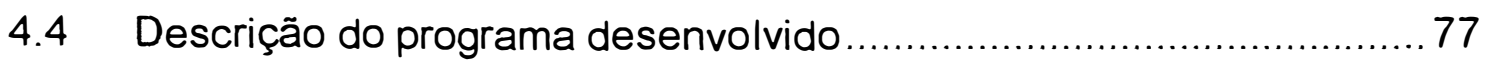

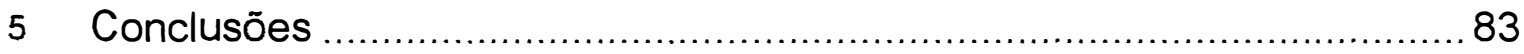

Anexo

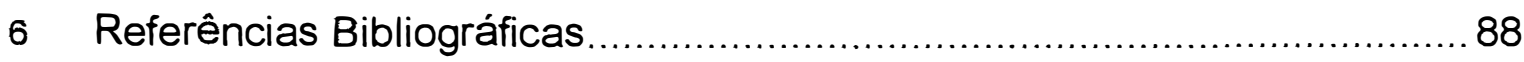




\section{LISTA DE TABELAS}

Página

Tabela 1. Dados meteorológicos externos utilizados para verificar o comportamento do modelo ESTUFA ....................................... 52

Tabela 2. Dados utilizados na resolução do modelo ESTUFA .........................52

Tabela 3. Coeficientes utilizados na simulação pelo modelo ESTUFA ............54

Tabela 4. Dados de entrada do modelo ESTUFA utilizados na análise de sensibilidade.

Tabela 5. Condições meteorológicas externas utilizadas na análise de sensibilidade, do dia 14 de abril de 1998.

Tabela 6. Coeficientes utilizados no teste do modelo ESTUFA com dados de campo

Tabela 7. Temperatura e umidade relativa do ar e diferença entre temperatura do ar interna e externa, simuladas durante o verão e inverno e sob estufa com cortinas aberta e fechadas

Tabela 8. Amplitude de variação da temperatura e umidade relativa do ar simulada entre os limites inferior e superior de cada elemento testado.

Tabela 9. Regressão linear entre resultados simulados e medidos, para casade-vegetação com cortinas fechadas e abertas. Coeficiente angular e coeficiente de determinação da $\left(R^{2}\right)$ reta $1: 1$ do ajuste entre dados simulados e medidos. 


\section{LISTA DE FIGURAS}

Página

Figura 1. Esquema geral da casa-de-vegetação utilizada no modelo.

21

Figura 2. Esquema do balanço de radiação de onda longa e onda curta da casa-de-vegetação

Figura 3. Esquema em corte da casa-de-vegetação. 44

Figura 4. Fluxograma da rotina para resolução do modelo ESTUFA 50

Figura 5. Dados meteorológicos externos, do dia 08/07/1998, utilizados na simulação pelo modelo ESTUFA.

Figura 6. Dados meteorológicos externos, do dia 03/01/1999, utilizados na simulação pelo modelo ESTUFA..

Figura 7. Dados meteorológicos externos utilizados na análise de sensibilidade, do dia 14 de abril de 1998. 57

Figura 8. Variação da temperatura e umidade relativa do ar, interna e externamente, em dia de inverno e com casa-de-vegetação com cortinas abertas 62

Figura 9. Variação da temperatura e umidade relativa do ar, interna e externamente, em dia de inverno e com casa-de-vegetação com cortinas fechadas. 63

Figura 10. Variação da temperatura e umidade relativa do ar, interna e externamente, em dia de verão e com casa-de-vegetação com cortinas abertas.

Figura 11. Variação da temperatura e umidade relativa do ar, interna e externamente, em dia de verão e com casa-de-vegetação com cortina fechadas. 64 
Figura 12. Densidade de fluxo diário dos componentes do balanço de energia no ar da estufa simulados para verão e inverno e sob casa-devegetação com cortinas abertas e fechadas. 65

Figura 13 Densidade de fluxos de energia diário gerados pelo modelo.. 66

Figura 14. Temperatura e umidade relativa do ar interna, simulada e medida, para a condição de casa-de-vegetação com cortinas fechadas (10/11/1999).

Figura 15. Temperatura e umidade relativa do ar interna, simulada e medida, para a condição de casa-de-vegetaçāo com cortinas abertas (23/11/1999).

Figura 16. Retas de ajuste entre temperatura e umidade relativa do ar, estimada e simulada, para casa-de-vegetação com cortinas fechadas (10/11/1999) e abertas (23/11/1999).

Figura 17. Variação do fluxo de calor no solo $\left(G, W \cdot m^{-2}\right)$ e da radiação líquida $\left(\mathrm{Rn}, \mathrm{W} . \mathrm{m}^{-2}\right)$ ao longo do dia em casa-de-vegetação com cortinas fechadas (10/11/1999) e abertas (23/11/1999). 75

Figura 18. Comparação entre valores simulados e medidos de fluxo de calor no solo $\left(G, W \cdot m^{-2}\right)$ e da radiação líquida $\left(R n, W \cdot m^{-2}\right)$ em casa-devegetação com cortinas fechadas (10/11/1999) e abertas (23/11/1999). .76

Figura 19. Tela inicial do programa de simulação. .78

Figura 20. Tela do programa ESTUFA para entrada de dados sobre a casa-devegetação. 79

Figura 21. Tela do programa para entrada de dados sobre o solo, cultura e ar na casa-de-vegetação. 80

Figura 22. Tabela de resultados do programa de simulação. 80 
Figura 23. Gráfico gerado pelo programa de simulação como a variação da temperatura e umidade relativa do ar, interna e externamente a casa-

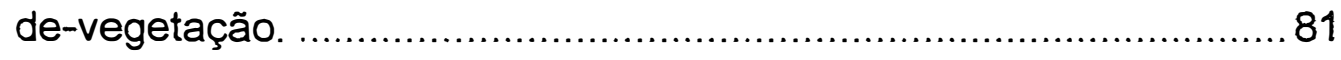




\section{LISTA DE SÍMBOLOS E ABREVIATURAS}

$\sigma$

$\Delta \rho i$

$\rho_{a r}$

$\varepsilon_{d}$

$\Delta e$

$\varepsilon_{e}$

$\rho e$

$\rho i$

$\alpha_{O C c}$

$\tau_{O C c}$

$\tau_{O C f}$

$\alpha_{O L c}$

$\tau_{O L c}$

$\varepsilon_{p}$

$\varepsilon_{s}$

$\Delta t$

$\Delta T a r$

$\Delta z$

$A C w^{0,5}$

$a e b$

$A$ e $B$

$A_{\text {arco }}$

$A_{\text {arcoL }}$

$A_{\text {arcosup }}$ calor latente de vaporização da água, $\mathrm{J} \mathrm{kg}^{-1}$

comprimento angular do arco da estufa, rad

constante de Stefan-Boltzmann

variação da umidade especifica, dentro de um passo de tempo $\Delta t$

massa específica do $\mathrm{ar}, \mathrm{kg} \mathrm{m}^{-3}$

emissividade do dossel da cultura

déficit de pressão de vapor, $\mathrm{kPa}$

emissividade da atmosfera

umidade especifica do ar no exterior da estufa, $\mathrm{kg} \cdot \mathrm{m}^{-3}$

umidade específica do ar no interior da estufa, $\mathrm{kg} \cdot \mathrm{m}^{-3}$

absortância da cobertura à radiação de onda curta

transmissividade da cobertura à radiação de onda curta

transmissividade da folha à radiação de onda curta

absortância da cobertura à radiação de onda longa

transmissividade da cobertura à radiação de onda longa

emissividade do material de cobertura da estufa

emissividade do solo

diferencial de tempo, passo de tempo, $s$

variação da temperatura do ar, dentro de um passo de tempo $\Delta t$ espessura de cada subdivisão do perfil do solo, $m$

produto entre coeficiente de descarga e coeficiente de efeito do vento coeficientes empíricos da equação de transpiração coeficientes para equação do $K c$ de perda de energia pela cobertura superfície coberta na região do arco, $\mathrm{m}^{2}$ superfície coberta nas extremidades da região do arco, $\mathrm{m}^{2}$ superfície coberta na parte superior da região do arco, $\mathrm{m}^{2}$ 
superficie coberta total da estufa, $\mathrm{m}^{2}$

área de janelas abertas, $\mathrm{m}^{2}$

$A_{\text {laterais }}$

superfície coberta na região da base da estufa (laterais), $\mathrm{m}^{2}$

As área de solo coberta pela estufa, $\mathrm{m}^{2}$

área total de abertura, $\mathrm{m}^{2}$

$B O C_{d}$

balanço de onda curta no dossel, $\mathrm{W} \mathrm{m}^{-2}$

$B O C_{s}$ balanço de onda curta na superficie do solo, $\mathrm{W} \mathrm{m}^{-2}$

$B O L_{d}$ balanço de onda longa no dossel, $\mathrm{W} \mathrm{m}^{-2}$

$B O L_{s}$ balanço de onda longa na superfície do solo, $\mathrm{W} \mathrm{m}^{-2}$

Comp comprimento da estufa, $\mathrm{m}$

capacidade térmica do solo, $\mathrm{J} \mathrm{m}^{-3} \mathrm{~K}^{-1}$

taxa de transpiração da cultura, $\mathrm{kg} \mathrm{m}^{-2} \mathrm{~s}^{-1}$

$e_{a}$

pressão atual do vapor, $\mathrm{kPa}$

$e_{s}$

pressão de saturação do vapor, $\mathrm{kPa}$

G

$h$

fluxo de energia para o solo, $\mathrm{W} \mathrm{m}^{-2}$

$H$

altura do arco, $\mathrm{m}$

Har

altura do pé direito, $m$

Hc

densidade de fluxo de energia para o ar da estufa, W. $\mathrm{m}^{-2}$

$H_{\text {conv }}$ perdas de energia através da cobertura, W. $\mathrm{m}^{-2}$

$H_{\text {dar }}$ calor sensivel por convecção do solo para o ar, $\mathrm{W} \mathrm{m}^{-2}$ calor sensivel do dossel para o ar, $\mathrm{W} \mathrm{m}^{-2}$

hs

$h v$

$H_{\text {vent }}$ calor sensivel da cobertura para o ar da estufa, $\mathrm{W} \mathrm{m}^{-2}$ coeficiente de transferência de calor sensivel por convecção, $\mathrm{W} \mathrm{m}^{-2} \mathrm{~K}^{-1}$ coeficiente de perda de calor pela ventilação, $\mathrm{W} \mathrm{m} \mathrm{m}^{-2} \mathrm{~K}^{-1}$

$I A F \quad$ indice de área foliar, $\mathrm{m}^{2} \mathrm{~m}^{-2}$ coeficiente de extinção do dossel

Kc coeficiente geral de perda de energia da cobertura, $W \mathrm{~m}^{-2} \mathrm{~K}^{-1}$

$K_{T}$ condutividade térmica do solo, $\mathrm{J} \mathrm{m}^{-1} \mathrm{~s}^{-1} \mathrm{~K}^{-1}$ 
calor latente de transpiração, $\mathrm{W} \mathrm{m}^{-2}$

Larg largura da estufa, $m$

taxa de ventilação do ar da estufa, $\mathrm{s}^{-1}$

No

taxa de infiltração ou taxa de ventilação básica, $\mathrm{s}^{-1}$

$P a b$

percentual de abertura das cortinas/janela.

R

raio da curvatura do arco da estufa, $m$

$\operatorname{Rg}$

radiação solar global fora da estufa, $\mathrm{W} \mathrm{m}^{-2}$

Rgi

radiação solar no interior da estufa, $\mathrm{W} \mathrm{m}^{-2}$

rOCd

refletância do dossel à radiação de onda curta

rocf

refletância da folha à radiação de onda curta

rOCs

refletância do solo à radiação de onda curta

RoLc

radiação de onda longa total proveniente da cobertura, $\mathrm{W} \mathrm{m}^{-2}$

$r_{O L C}$

reflectância da cobertura á radiação de onda longa

RoLd

radiação de onda longa emitida pelo dossel, $\mathrm{W} \mathrm{m}^{-2}$

$R_{\text {OLex }}$

radiação de onda longa emitida pela atmosfera, $\mathrm{W} \mathrm{m}^{-2}$

$R_{O L i}$

radiação de onda longa externa transmitida pela cobertura, $\mathrm{W} \mathrm{m}^{-2}$

$R_{O L p}$

radiação emitida pela cobertura, $\mathrm{W} \mathrm{m}^{-2}$

$R_{O L S}$

radiação de onda longa emitida pelo solo, $\mathrm{W} \mathrm{m}^{-2}$

Td

transmissibilidade do dossel

Te

Ti

temperatura do ar externo, $\mathrm{K}$ ou ${ }^{\circ} \mathrm{C}$

$T s$

temperatura do ar no interior da estufa, $\mathrm{K}$ ou ${ }^{\circ} \mathrm{C}$

$U$

temperatura na superfície do solo, $\mathrm{K}$

$V_{\text {arco }}$

velocidade do vento externa, $\mathrm{m}^{2}$

Vol

volume de ar na região do arco da estufa, $\mathrm{m}^{3}$

$W_{a r}$

volume total da estufa, $\mathrm{m}^{3}$

$W_{\text {vent }}$

fluxo de vapor d'água para o ar da estufa, $\mathrm{kg} \cdot \mathrm{m}^{-3} \cdot \mathrm{s}^{-1}$

perda de vapor d'água através da ventilação, $\mathrm{kg} \cdot \mathrm{m}^{-3} \cdot \mathrm{s}^{-1}$ 


\title{
MODELAGEM DO MICROCLIMA EM CASA-DE-VEGETAÇÃO
}

\author{
Autor: ROBERTO T. ATARASSI \\ Orientador: Prof. Dr. ROGÉRIO TEIXEIRA DE FARIA
}

\section{RESUMO}

O cultivo em casas-de-vegetação é uma atividade que cresceu muito nas últimas décadas e permite uma série de vantagens: aumento de produtividade, produtos de alta qualidade, precocidade, proteção contra intempéries climáticas. Entretanto, na mesma grandeza das vantagens, existem desvantagens como ocorrência de temperaturas elevadas, controle da umidade do ar e penetração inadequada de luz. O entendimento e o manejo do microclima no interior das casas-de-vegetação é imprescindivel para um bom desenvolvimento das culturas. Devido à complexidade nas interações entre os elementos de uma casa-de-vegetação, como clima local, cultura e características da construção, a modelagem mostra-se como uma ferramenta de grande utilidade para o estudo deste sistema de produção e possibilita um maior entendimento dos processos, auxiliando no dimensionamento e manejo das estruturas no campo, além de aplicações em processos de otimização, indicando estratégias mais adequadas para o manejo da cultura e aumento dos rendimentos.

Pelo exposto, o trabalho teve como objetivo o desenvolvimento de um modelo matemático, denominado ESTUFA, para estimar o comportamento do microclima em casa-de-vegetação a partir de dados meteorológicos externos e 
sua implementação na forma de um programa de simulação. O modelo ESTUFA foi baseado em equações de balanços de energia e massa dos vários subsistemas, como ar interno, cobertura da casa-de-vegetação, cultura e solo, e solucionado numericamente pela implementação em linguagem de programação Delphi 3.0. Por meio de uma interface amigável, o programa possibilita a organização de coeficientes e dados de entrada do modelo, incluindo o uso de arquivos com os elementos meteorológicos externos (radiação solar global, temperatura e umidade relativa do ar, e velocidade do vento). O programa fornece,como resultados, as estimativas de temperatura e umidade relativa do ar no interior da casa-de-vegetação, além da evolução dos fluxos de energia ao longo do tempo.

A execução do modelo com dados externos, em duas épocas do ano (inverno e verão) e para duas condições, fechada e aberta durante o dia, mostraram que o comportamento foi condizente com os resultados levantados na literatura. Comparações com dados de campo indicaram que o comportamento da temperatura e umidade relativa do ar simuladas, seguem um comportamento similar aos medidos, necessitando de ajustes nos coeficientes do modelo.

A análise de sensibilidade utilizando o modelo ESTUFA revelou que os fatores que mais afetaram a temperatura do ar no interior da casa-de-vegetação foram: temperatura do ar externa, coeficiente de extinção, percentual de abertura de cortinas e transmissividade da cobertura à radiação de onda longa. A umidade relativa do ar interna foi principalmente influenciada pela umidade relativa do ar externa, coeficiente de extinção do dossel, percentual de abertura das cortinas e temperatura do ar externa.

Modelo ESTUFA se mostrou útil no entendimento da formação do microclima em casas-de-vegetação, além de permitir a visualização da magnitude de cada um dos componentes que influenciam 0 seu comportamento. Futuros trabalhos ainda são necessários para a validação e 
melhorias no modelo, ligadas especialmente à ventilação, evapotranspiração e balanço de radiação na cultura em casas-de-vegetação. 


\title{
MODELING OF GREENHOUSE MICROCLIMATE
}

\author{
Author: ROBERTO T. ATARASSI \\ Adviser: Prof. Dr. ROGÉRIO TEIXEIRA DE FARIA
}

\section{SUMMARY}

Cultivation in greenhouses is an activity that has been increased significantly during the last decades and has several advantages like yield increasing, high quality products, early yields and protection against climatic adversity. However, there are important disadvantages, such as difficulties to decrease high air temperature, deficient control of relative humidity and unsuitable light penetration. A good understanding of the greenhouse microclimate and also its management is crucial for achieving high crop yield. Due to the complex interaction among the components of a greenhouse, mostly local climate, crop and building characteristics, modeling represents a powerful tool for studying this production system. Simulation allows a better understanding of the processes, which is of great importance for designing and managing the structures, and also makes it possible to optimize management and profit.

The objective of the present work was to develop a mathematical model, named as ESTUFA, to predict microclimate inside a greenhouse using external meteorological data and its implementation to computer program. The model, named "ESTUFA", was developed, based on energy and mass balance equations, applied to several subsystems, like inside air, cover, crop and soil, and solved numerically by computer language routine (Delphi 3.0). The 
developed software allowed handling of all coefficients of the model, including the use of input files with external meteorological data (global solar radiation, air temperature, relative humidity and air velocity). The program output predicts air temperature and air relative humidity inside the greenhouse, and the energy flux density of all components of the energy balance.

Tests made with external data, from two seasons (summer and winter) and two conditions (closed greenhouse and greenhouse opened during the day), showed an agreement behavior compared to the results from literature. Comparisons with real conditions indicated that simulated air temperature and the air relative humidity when behavior follow the measured ones, denoting the necessity of coefficients calibration.

Sensitivity analyses using model ESTUFA showed that the most important factors for simulated inside air temperature were: external air temperature, extinction coefficient of canopy, proportional aperture of windows and long wave transmissivity of cover. The air relative humidity was affected mainly by external air relative humidity, extinction coefficient of canopy, proportional aperture of windows and external air temperature.

The model ESTUFA was proved to be useful for understanding the behavior of greenhouses microclimate and allowed the visualization of each component that forms this environment. Future works are necessary to validate and improve the model, especially for ventilation, evapotranspiration and radiation balance of crops, for Brazilian conditions. 


\section{INTRODUÇÃO}

O cultivo em casas-de-vegetação é uma atividade que cresceu muito nas últimas décadas. Iniciou-se nos anos 40 e 50 em países como Estados Unidos, Japão e Holanda, que tinham suas produções restritas, devido ao clima frio, e expandiu-se rapidamente pelo mundo (Nelson, 1991). Inicialmente as construções eram feitas de vidro, mas o grande impulso foi dado com o desenvolvimento dos plásticos, nos anos 30 , que proporcionaram estruturas mais leves e baratas, permitindo um maior acesso dos produtores a essa tecnologia.

No princípio, as casas-de-vegetação foram desenvolvidas para possibilitar o cultivo nos climas frios dos seus países de origem, porém expandiu-se também em regiões quentes e secas, a exemplo das extensas áreas cobertas nos desertos de Israel, região da Almeria na Espanha, Califórnia, que hoje são grandes produtores de alimentos devido a essa tecnologia (Sganzerla,1995).

No Brasil um único tipo de casa-de-vegetação não se adaptaria às várias condições do território, tendo em vista a grande diversidade climática. O conhecimento do ambiente interno e sua relação com os outros fatores, como o clima local, característica da casa-de-vegetação e cultura, são fundamentais para a adoção de um manejo adequado, garantindo uma produção com qualidade e quantidade, a baixo custo, remunerando o agricultor $e$ disponibilizando o alimento à população. 
O cultivo em casas-de-vegetação permite uma série de vantagens: aumento de produtividade, qualidade de produto, precocidade, menor lixiviação dos nutrientes do solo, controle mais eficiente de pragas e doenças, proteção contra intempéries climáticas (chuva, vento, granizo, frio) (Oliveira, 1997). Entretanto, na mesma proporção que existem as vantagens, também existem as desvantagens. Oliveira (1995) enumera as principais: problemas de resfriamento do ambiente, controle deficiente da umidade do ar, penetração inadequada de luz, difícil controle de doenças e pragas depois de instaladas e potencial de ataque de pragas 0 ano inteiro. Também foi apontada a necessidade de pesquisa e a divulgação como parte dos problemas.

Nos últimos anos, muitas empresas se iniciaram no ramo da produção e comercialização de casas-de-vegetação, porém a maioria baseada em projetos originados de outros países, não adaptados, muitas vezes, às nossas condições.

Muitos trabalhos têm sido realizados, estudando o cultivo em casas-devegetação, mas ainda faltam dados sobre o comportamento do seu microclima nas condições brasileiras, principalmente ligados ao manejo da temperatura e umidade relativa do ar. Devido à complexidade da interação entre os vários elementos do sistema sobre o microclima, a modelagem tem se mostrado um importante instrumento para o estudo em casas-de-vegetação. Entretanto, trabalhos utilizando esta abordagem são praticamente inexistentes no Brasil, restringindo-se unicamente à utilização de programas de controle ambiental em casas-de-vegetação climatizadas, trazidas de países com maior tradição nesta forma de cultivo.

Diante do exposto, o trabalho teve como objetivo o desenvolvimento de um modelo matemático, denominado de ESTUFA, para estimativa das condições microclimáticas no interior de casas-de-vegetação e sua implementação na forma de um programa de simulação, tendo como dados de 
entrada as condições meteorológicas externas, caracteristicas da construção e de manejo. 


\section{REVISÃO DE LITERATURA}

\subsection{Cultivo em Casas-de-Vegetação}

A origem e o desenvolvimento de casas-de-vegetação ocorreram nos países do Hemisfério Norte, em função de suas necessidades e dificuldades de produção durante no inverno (Nelson, 1991). As maiores conquistas no cultivo em casas-de-vegetação, iniciada no século passado, foram oriundas do vidro, mas o grande impulso foi dado com o desenvolvimento do plástico. Em 1930 foi criado o polietileno, que se tornou material plástico pioneiro utilizado como cobertura de casas-de-vegetação na metade do século.

Os filmes plásticos proporcionaram estruturas mais leves, práticas e baratas comparadas com as estufas de vidro, o que permitiu um maior acesso dos produtores a essa tecnologia, ampliando rapidamente a sua utilização em várias partes do mundo (Nelson, 1991; Sganzerla, 1995). Atualmente, o polietileno de baixa densidade (PEBD) é o plástico mais utilizado na agricultura (Sganzerla, 1995), representando mais de $90 \%$ do volume aplicado mundialmente.

A utilização de casas-de-vegetação não se limita apenas ao cultivo em regiões frias (Sganzerla, 1995). Muitas regiões do mundo são hoje agricultáveis graças a essa tecnologia, como são os casos dos desertos do Oriente Médio e Israel, Sul da Califórnia e região da Almeria na Espanha. Nestes locais, a casade-vegetação permite um melhor controle ambiental, protegendo as plantas contra intempéries como ventos fortes, chuva, granizo e excesso de luz, que associados a um bom manejo da água, permitem altas produções. 
Segundo Goto (1993), no Brasil, desde 1970, tem havido notícias da utilização de plásticos na agricultura, sendo que nos anos 80 houve uma maior procura desta tecnologia. Mesmo com desenvolvimento dos cultivos protegidos, - Brasil ainda está muito aquém do seu potencial. Siqueira (1996) afirma que o consumo nacional de plásticos gira em torno de 25.000 t/ano para as chamadas aplicações diretas (cobertura do solo, túneis e casas-de-vegetação). Embora esse valor duplique, considerando as aplicações indiretas (silos e irrigação), está longe da estimativa de consumo potencial de 280.000 t/ano.

O cultivo em casas-de-vegetação promove inúmeras vantagens. Oliveira (1997) e Sganzerla (1995) listam as principais:

- Aumento de produtividade, podendo atingir 3 a 5 vezes mais que a campo;

- Colheita na entressafra, tanto aproveitando o "efeito guarda-chuva", contra o excesso de chuva no verão, como contra o frio rigoroso do inverno, em regiões como nos Estados do Sul, permitindo boas produções durante $o$ ano todo;

- Precocidade das colheitas, obtida pelas melhores condições ambientais internas;

- Melhor qualidade dos produtos, tanto no aspecto como no sabor;

- Controle mais eficiente de doenças e pragas, conseguido com o melhor controle da umidade e temperatura do ar, reduzindo a disseminação e desenvolvimento de doenças. A entrada de pragas é evitada pela cobertura e proteção lateral (telados). Os defensivos agrícolas também são mais eficientes, por não sofrerem lavagem pelas chuvas, e podem ser usados em doses menores, comparadas às utilizadas a céu aberto;

- Menor lavagem de adubos, por não haver lixiviação pela chuva; 
- Proteção contra adversidades climáticas como chuvas excessivas, granizo, seca, ventos etc.

Porém, nem tudo são vantagens nos cultivos protegidos. Oliveira (1995) menciona que a uniformidade genética das culturas resulta em um ambiente anormal do ponto de vista ecológico, que associado às características de local fechado (alta umidade relativa, altas temperaturas e má circulação do ar) e um manejo inadequado, potencializa a ocorrência de doenças e pragas. A falta de inimigos naturais também contribui para isso. Em um levantamento realizado pela autora, as principais desvantagens são citadas: resfriamento e controle da umidade relativa do ar ineficientes, prejudicando o desenvolvimento das plantas; penetração inadequada de luz, causando estiolamento das plantas; doenças mais agressivas e difíceis de tratar, principalmente as de solo; salinização do solo; falta de pesquisa e divulgação para melhoria das técnicas de manejo em casas de vegetação; proliferação de pragas por falta de inimigos naturais.

\subsection{Microclima no INTERIOR de CASAS-DE-Vegetação}

\subsubsection{Radiação Solar em Casas-de-vegetação}

A radiação solar global no interior de uma casa-de-vegetação é menor que a observada no exterior, devido aos processos de absorção e reflexão do material de cobertura (Martin et al., 1982). O polietileno de baixa densidade (PEBD) possui boa transparência à radiação solar, deixando passar, em média, de 59 a 90\% (Farias et al., 1993a; Camacho et al., 1995; Fernandes, 1996; Souza \& Escobedo, 1996; Sentelhas et al., 1997; Folegatti et al., 1997).

Entretanto, a transmissividade varia conforme características da cobertura (tipo de material plástico, deposição de poeira, sombreamento da estrutura de sustentação) e o ângulo de inclinação dos raios solares, que é 
condicionado à orientação e arquitetura da casa-de-vegetação, estação do ano e horário do dia (Pezzopane et al., 1995b).

Farias et al. (1993a), trabalhando com PEBD, observaram que a maior transmissividade à radiação solar (93\%) ocorreu entre 14 e 16 horas, sendo menor próximo ao nascer e pôr do sol, mostrando que a transmissividade varia em função do ângulo de incidência da radiação solar. Camacho et al. (1995) encontraram resultados semelhantes, verificando também que a transmissividade no inverno foi menor que no verão, isso devido à maior inclinação dos raios solares e à maior camada de condensação que aumenta a reflexibilidade do plástico.

A cobertura plástica promove também um efeito dispersante sobre a radiação global. Farias et al. (1993a) relataram que, em dias de céu limpo, 45\% da radiação global correspondia a radiação difusa no interior da casa-devegetação de PEBD, enquanto que externamente esse valor era de $24 \%$. Este efeito dispersante é interessante por que a luz difusa é multidirecional, penetrando melhor entre as folhas e que compensaria em parte a parcial opacidade do filme plástico à radiação solar. A radiação difusa interna à casade-vegetação torna-se maior que a externa apenas quando a radiação solar externa é composta basicamente por radiação difusa. Neste caso, a luz sofreria somente a ação da transmissividade do plástico. Camacho et al. (1995) também encontraram comportamento semelhante. Ricieri \& Escobedo (1996) concluíram que é possível determinar a radiação difusa e direta no interior de casas-devegetação a partir dos seus dados externos.

Esses resultados podem ser influenciados pelo acúmulo de camada de condensação de vapor d'água, que aumenta a difusibilidade do plástico, fato constatado por Camacho et al. (1995) e Ricieri \& Escobedo (1996), e pelo maior número de estruturas de sustentação, como visto por Ricieri \& Escobedo (1996). 
A transmissividade depende também do comprimento de onda. Em geral, - polietileno de baixa densidade possui alta transparência na faixa do ultravioleta $(<300 \mathrm{~nm})$, e uma redução na faixa do infravermelho. Segundo Robledo de Pedro \& Vicente ${ }^{1}$ citados por Pezzopane et al. (1995b) o PEBD transmite até $80 \%$ de radiação de onda longa, dado comprovado por Martins et al. (1994). Sendo assim, o efeito estufa, ou seja, a retenção de ondas longas, seria pequena, determinando temperaturas do ar mínimas noturnas no interior da casa-de-vegetação não muito diferentes do ambiente exterior. Dependendo das condições podem ocorrer dias em que a temperatura mínima no interior da casa-de-vegetação seja inferior, originando o fenômeno da inversão térmica (Tapia ${ }^{2}$, citado por Buriol et al., 1993). Outros tipos de plástico, os chamados "plásticos térmicos", como EVA, PEBD térmico, têm menor transparência à radiação de onda longa, evitando a queda acentuada da temperatura do ar (Sganzerla, 1995; Baytorun et al., 1994).

Martins et al. (1994) lembram também que o vapor d'água, que pode concentrar ainda mais sob cobertura plástica, tem importante absorção na região de 935,810 e $780 \mathrm{~nm}$, reduzindo as perdas de calor.

\subsubsection{Temperatura do ar}

A temperatura do ar no interior de casas-de-vegetação está intimamente ligada ao seu balanço de energia. Depende, portanto, dos processos de incidência da radiação solar, reflexão e reirradiação através dos objetos no interior da casa-de-vegetação, convecção e condução através da cobertura e

${ }^{1}$ ROBLEDO DE PEDRO, F.; VICENTE, L.M. Aplicacion de los plasticos em la agricultura. 2 ed. Madrid: Mundi-Prensa, 1988. 573p.

2 TAPIA, G.J. Filmes térmicos para invemaderos. Revista de los plásticos modernos, Espanha, v.295,p.75-82, 1981. 
paredes, renovação do ar e troca de calor com o solo (Cermeño, s.d.; Jarvis, 1993; Farias et al., 1993b). Desta forma, características que afetam tais processos de ganho e perda de energia, como volume de ar da casa-devegetação, condição atmosférica externa, área da superfície coberta, transmissividade da cobertura, área de aberturas, ventilação, cobertura do solo, também condicionarão a temperatura do ar nas casas-de-vegetação.

O efeito da cobertura plástica sobre a temperatura do ar ocorre principalmente sobre as máximas. Farias et al. (1993b), trabalhando com casade-vegetação de PEBD, em Pelotas, RS, encontraram médias das máximas entre 1,2 a $4,4^{\circ} \mathrm{C}$ acima das verificadas a céu aberto. $O$ pequeno volume e menor renovação de ar nas casas-de-vegetação promovem o seu aquecimento durante o período diurno, que se intensifica quando mantida fechada (Farias et al., 1993b; Camacho et al., 1995).

Camacho et al. (1995) encontraram as maiores diferenças nas temperaturas do ar máximas interna e externa nos meses mais quentes do ano, podendo atingir niveis prejudiciais a culturas como tomate, pepino e alface, o que foi atribuído à dificuldade de ventilação da estufa tipo túnel alto, onde realizaram a pesquisa.

Pezzopane et al. (1995a) verificaram temperaturas do ar máximas sempre maiores dentro da casa-de-vegetação tipo arco, localizada no município de Campinas, Estado de São Paulo. As temperaturas altas puderam ser evitadas através da abertura das cortinas.

Já os valores médios, internos e externos, das temperaturas do ar mínimas são muito semelhantes (Farias et al., 1993b; Camacho et al., 1995). Buriol et al. (1993), também trabalhando no Rio Grande do Sul, verificaram médias das temperaturas do ar mínimas entre 1 a $3^{\circ} \mathrm{C}$ superiores às do ambiente externo. Heldwein et al. (1996) encontraram ganhos de até $2^{\circ} \mathrm{C}$ sobre as temperaturas do ar mínimas em casas-de-vegetação instaladas no mesmo 
local, mas que ainda são insuficientes para o cultivo da maioria das hortaliças nesta região.

As médias de temperaturas do ar encontradas por Fernandes (1996) foram de $32,9^{\circ} \mathrm{C}$ e $28,8^{\circ} \mathrm{C}$ para as máximas, $23,7^{\circ} \mathrm{C}$ e $21,8^{\circ} \mathrm{C}$ para as médias, e $17,3^{\circ} \mathrm{C}$ e $16,7^{\circ} \mathrm{C}$ para as mínimas, respectivamente, no interior e exterior de casas-de-vegetação cultivadas com crisântemo e situadas no Estado de São Paulo.

Camacho et al. (1995) observaram temperaturas mínimas do ar, em casa-de-vegetação de PEBD, inferiores ao exterior durante o período de junho a meados da primavera. Este fenômeno, denominado "inversão térmica", é devido à alta transmissividade do PEBD à radiação de onda longa (infravermelho), que permite grande perda de energia durante o período noturno. A redução da temperatura do ar ainda é auxiliada pela falta de movimentos verticais e horizontais de massas de ar no interior da casa-devegetação, que, em condições de céu aberto, transportariam energia entre camadas, reduzindo o resfriamento contínuo. A inversão térmica ocorre em dias limpos, tanto com ventos calmos como fortes (Buriol et al., 1993; Farias et al., 1993b; Camacho et al., 1995). Entretanto, Pezzopane et al. (1995a) ressalta que o PEBD, mesmo retendo pouca radiação térmica, uma pequena variação no balanço energético pode reduzir a taxa de resfriamento.

Buriol et al. (1993) ressaltam que, quando ocorre a inversão térmica, não há risco de geadas radiativas, pois as temperaturas interna e externa são relativamente elevadas. Os mesmos autores constataram que os maiores ganhos nas temperaturas mínimas do ar ocorrem em dias frios, chegando a atingir diferenças de até $6,4^{\circ} \mathrm{C}$ a favor das casas-de-vegetação. Isso foi atribuído à formação de uma camada de água condensada na superfície interna nesse período, que reduz as perdas de calor por radiação. Resultados semelhantes foram obtidos por Pezzopane et al. (1995a), que verificaram a 
inversão térmica apenas em dias com temperatura mínima do ar maior que $14^{\circ} \mathrm{C}$ e maiores saltos térmicos nos dias mais frios.

O uso de casas-de-vegetação para obtenção do efeito "guarda-chuva", no qual se deseja a proteção da cultura contra o excesso de chuvas, granizo e umidade, tende a não alterar muito a temperatura do ar interna. Martins et al. (1994) obtiveram dentro da casa-de-vegetação, com laterais totalmente abertas e efeito guarda-chuva, médias das temperaturas do ar mínimas, médias e máximas ligeiramente maiores, entre 1 a $2^{\circ} \mathrm{C}$, demonstrando sua funcionalidade, sem grandes aumentos na temperatura. Os picos de temperaturas, por volta de $35^{\circ} \mathrm{C}$, foram em média $2^{\circ} \mathrm{C}$ acima do ambiente externo. Os autores atribuem esses resultados às dimensões da casa-devegetação ( 8 x25m, 1,7m de pé-direito), favorecendo a ventilação. Reis (1997) encontrou temperaturas sempre maiores no interior de uma casa-de-vegetação tipo guarda-chuva, mas ainda assim permitiu um bom desenvolvimento da cultura, protegendo contra o excesso de chuvas.

\subsubsection{Umidade Relativa do Ar}

A umidade relativa do ar influencia a transpiração, o crescimento, a fecundação das flores e a ocorrência de doenças (Cermeño, s.d.). Altos valores de umidade relativa do ar reduzem a taxa de evapotranspiração da cultura. Quando associados a altas temperaturas do ar geram também condições muito favoráveis à ocorrência de doenças. Já valores muito baixos de umidade relativa podem provocar altas taxas de evapotranspiração, que podem reduzir a taxa fotossintética e, conseqüentemente, a produção da cultura.

Em condições normais e típicas, a umidade relativa do ar tem comportamento contrário ao da temperatura do ar, ou seja, valores elevados durante o período noturno e baixos durante o período diurno. Isso acontece em razão de a pressão de saturação de vapor aumentar exponencialmente com a 
temperatura do ar e da pequena variação da pressão atual de vapor ao longo do dia (Pezzopane et al., 1995a).

O mesmo autor, trabalhando em casa-de-vegetação, coberta com filme de polietileno, com manejo de cortinas laterais, observou pressões de vapor atuais maiores no interior do que a céu aberto. Os maiores valores ocorreram de manhã. A não renovação do ar associada à incidência dos primeiros raios solares, aumentando a evapotranspiração, acentua a elevação da pressão atual de vapor. Com a abertura das cortinas de manhã, esses valores decaem rapidamente, subindo novamente com o fechamento das laterais no período da tarde.

Em geral, o valor da umidade relativa máxima é maior dentro da casa-devegetação do que no ambiente externo. Farias et al. (1993b) encontraram médias das máximas no interior da casa-de-vegetação $(95,6$ a 99,2\%) superiores aos verificados a céu aberto (91,4 a 99,0\%), na maior parte do experimento. Maiores umidades relativas máximas também foram encontrados por Pezzopane et al. (1995a). Esses valores ocorrem em geral à noite ou nas primeiras horas da manhã. A retenção do vapor d'água pelo filme plástico, associado à queda de temperatura do ar durante a noite, que reduz a tensão de saturação de vapor d'água, contribui para os maiores valores de umidade relativa do ar.

A forma de manejo pode alterar esse comportamento. Martins et al. (1994), fazendo uso de casa-de-vegetação efeito guarda-chuva, não encontraram grandes variações nos valores de umidade relativa do ar dentro e fora da casa-de-vegetação, ficando a média em torno e $80 \%$. A médias das máximas e mínima ficaram próximas a $100 \%$ e $45 \%$, respectivamente.

Quanto à umidade relativa mínima interna à casa-de-vegetação comparada com a externa, varia dependendo do manejo e idade da cultura. Pezzopane et al. (1995a) determinaram maiores valores de umidade relativa do ar no interior da casa-de-vegetação, devido principalmente aos maiores valores 
de pressão atual de vapor no interior. Durante as horas mais quentes do dia, os valores internos e externos foram praticamente os mesmos, mostrando a baixa influência da casa-de-vegetação sobre a umidade relativa mínima.

Farias et al. (1993b) verificaram médias de umidade relativa mínima menores no interior da casa-de-vegetação, o que foi justificado pelas maiores temperaturas do ar diurnas encontradas neste ambiente, que permite maior valor de tensão de saturação de vapor d'água. Com a casa-de-vegetação aberta neste período, a tensão atual de vapor não permanece muito acima da verificada externamente, propiciando menor valor de umidade relativa no interior da casa-de-vegetação, devido somente à maior tensão de saturação. Martins et al. (1994) também encontraram, em média, valores um pouco menores dentro da casa-de-vegetação.

Farias et al. (1993b) ainda mostraram que, no início do desenvolvimento, os valores de umidade relativa interna foram inferiores aos externos, ocorrendo em seguida um período de equilíbrio e, posteriormente, valores mais altos no interior. Isso é devido ao aumento da transpiração com o desenvolvimento da cultura, aumentando a pressão atual de vapor, conseqüentemente aumentando a umidade relativa do ar, acentuada pela pequena renovação da massa de ar interna.

Fernandes (1996), trabalhando em casas-de-vegetação de crisântemo com manejo de cortinas laterais, encontrou maior variação da umidade interna em relação à externa, possivelmente devido ao manejo das cortinas. As umidades relativas média, interna e externa, foram muito semelhantes $(74,8 \% \mathrm{e}$ $75,6 \%$, interna e externa, respectivamente). 


\subsubsection{Evapotranspiração}

A evapotranspiração é a somatória de dois termos: transpiração - água que penetra pelas raízes das plantas, utilizada na construção dos tecidos ou emitida pelas folhas, reintegrando-se à atmosfera - e evaporação, que é a água evaporada pelo terreno adjacente às plantas, por uma superfície de água ou pela superfície das folhas quando molhadas por chuva ou irrigação for evaporada sem ser usada pela planta (Klar, 1991).

A cobertura plástica altera o balanço de radiação e o balanço energético, com relação ao exterior. Conseqüentemente, altera a evapotranspiração (Farias et al., 1994). Considerando que o comportamento ambiental em casas-devegetação é diferente daquele encontrado a céu aberto, e, sendo a cobertura plástica impermeável à entrada de água das chuvas, torna-se extremamente importante um melhor conhecimento das exigências hídricas das plantas em seu interior, uma vez que a irrigação, na maioria das vezes, será a única forma de fornecimento de água às culturas e poderá afetar elementos como temperatura e umidade relativa do ar.

Em geral, no interior de casas-de-vegetação, a evapotranspiração é menor que a verificada externamente, o que se atribui basicamente à parcial opacidade da cobertura plástica à radiação solar e à redução da ação dos ventos, que são os principais fatores da demanda evaporativa da atmosfera. A diferença entre a evapotranspiração interna e externa varia de acordo com as condições meteorológicas. Em geral, a evapotranspiração no interior da casade-vegetação fica em torno de 60 a $80 \%$ da verificada no exterior (Montero et al., 1985; Farias et al., 1994; Martins \& Gonzalez, 1995).

Vários trabalhos têm sido realizados para estimar a evapotranspiração em casas-de-vegetação, como o uso de tanque reduzido e tanque Classe $A$ (Farias et al., 1994), correlações com características da planta, como altura e 
número de folhas (Dalmago et al., 1997), determinação do coeficiente de cultura (Dalsasso et al., 1997) e outros.

O uso de tanques evaporimétricos e dados, como altura de plantas e número de folhas, dificultam a sua aplicação em modelos devido à necessidade de leituras constantes, sendo mais interessante, neste caso, o uso de modelos de estimativas da evapotranspiração baseados em dados meteorológicos.

Em experimento realizado por Fernandes (1996) com crisântemo em casa-de-vegetação, o uso de modelos que utilizavam como entrada de valores a radiação solar e temperatura do ar (Jensen \& Haise, radiação solar, Makkink) forneceram melhores resultados para estimativa da ETR. Modelos mais complexos, como Penman, Penman-Monteith Penman-Piche, apresentaram resultados inferiores, mostrando a viabilidade do uso de modelos mais simples. O uso do mini tanque não gerou bons resultados, fato atribuído ao coeficiente do tanque $(\mathrm{Kp})$ não adequado à casa-de-vegetação e à não calibração com o tanque Classe $A$.

Folegatti et al. (1996) também não encontraram diferenças significativas entre modelos mais complexos e modelos mais simples em casas-devegetação com a cultura do crisântemo. Foi concluído que melhores modelos de estimativa da evapotranspiração são obtidos com elementos do interior da casa-de-vegetação.

Furlan (1996) concluiu que é possível estimar o consumo de água do crisântemo envasado, cultivado em casa-de-vegetação, a partir do número de dias após o transplante e do consumo de água no estágio de máximo consumo diário. Outros modelos, usando as variáveis área foliar, evaporação do tanque reduzido e evaporação do atmômetro de escala ampliada, forneceram boas estimativas da evapotranspiração.

Trabalhos, como de Jolliet \& Bailey (1992), têm mostrado bons resultados com equações do tipo: 


$$
E T c=a \cdot R g i+b \cdot \Delta e
$$

em que ETc é a evapotranspiração da cultura, Rgi, a radiação global no interior da estufa, $\Delta e$, o déficit de pressão de vapor, e a e $b$, coeficientes empíricos determinados para cada condição. Sbita et al. (1998) utilizaram o mesmo tipo de equação, mas com a determinação do coeficiente a em função do índice de área foliar e $\circ b$ em função do índice de área foliar e da resistência aerodinâmica, permitindo representar melhor o comportamento da cultura.

\subsubsection{Ventilação}

A ventilação natural é um dos principais mecanismos de controle do clima em casas-de-vegetação, responsável pelos balanços de energia e de massa (água e $\mathrm{CO}_{2}$ ), mas ainda é um parâmetro pouco estudado devido à complexidade da sua análise (Boulard et al., 1996).

Vários autores mostram a importância da ventilação para evitar a ocorrência de altas temperaturas do ar (Garnaud, 1974; Montero et al., 1985; Mills et al., 1990; Martins et al., 1994, Oliveira, 1997), que podem chegar a valores extremos de $40-50^{\circ} \mathrm{C}$ no verão, prejudiciais para as plantas e dificultando o trabalho das pessoas neste ambiente. Também indicam a necessidade de maiores estudos quanto à ventilação natural, procurando estudar estruturas e técnicas que melhorem a eficiência das trocas de ar, como o aproveitamento do efeito "chaminé", com a abertura na cobertura.

Garnaud (1974) e Oliveira (1997) listam os principais propósitos da ventilação:

- Redução do nível de umidade sob a cobertura plástica;

- Manutenção da umidade e gases $\left(\operatorname{como} \mathrm{O}_{2}, \mathrm{CO}_{2}\right)$ bem distribuída dentro da estufa; 
- Renovação da atmosfera interna substituição de $\mathrm{CO}_{2}$;

- Redução de altas temperaturas do ar.

Características da casa-de-vegetação, como uso de telas antiinsetos e aberturas na cumeeira (efeito chaminé), alteram as características de ventilação natural, afetando conseqüentemente o seu clima (Montero et al., 1997; Boulard \& Baile, 1993).

É interessante em regiões mais quentes que se aproveite a ventilação natural, com uso de casas-de-vegetação com aberturas laterais e na cobertura, aproveitando tanto o efeito do vento como o movimento convectivo do ar (efeito chaminé) (Rault, 1990; Mills et al., 1990). Rault (1990) indica que a ventilação forçada muitas vezes não se justifica em regiões quentes devido ao alto investimento e por não serem efetivos no abaixamento da temperatura do ar.

Martins et al. (1994), encontraram valores de temperatura e umidade relativa do ar semelhante entre o ambiente interno e externo em casa-devegetação tipo "guarda-chuva", o que foi atribuído as suas características de boa ventilação.

Estudos com modelagem aplicada à ventilação em casas-de-vegetação podem ser vistos nos trabalhos de Boulard \& Baille (1993), Boulard et al. (1996), Kittas et al. (1997), Mistriotis et al. (1997), onde é mostrado que a velocidade do vento fora da estufa é linearmente correlacionada com a taxa de ventilação (medido em termos de número de renovações de ar por um intervalo de tempo) quando é mantida constante a área total de aberturas. Também é mostrado que a área total de aberturas afeta linearmente a taxa de ventilação, sendo mais eficientes aberturas laterais associadas com abertura na cobertura. Os modelos podem ser mais complexos quando são incorporadas características como ventilação forçada, sistemas de aquecimento, nebulizadores para resfriamento do ambiente e evapotranspiração da cultura. 


\subsection{Modelagem EM CASAS-DE-VEgetAÇÃo}

Segundo Pessoa et al. (1997), um modelo é uma representação de um sistema em uma determinada linguagem, não sendo necessariamente a linguagem matemática (uma maquete, por exemplo, é um modelo físico), mas, com a popularização dos computadores e a facilidade na realização simulações, implementação de algoritmos para controle de sistemas, os matemáticos são os mais disseminados, tanto para aplicações científicas como comerciais.

Segundo Hanan (1998) a simulação através de modelos é um processo barato para o estudo do clima e da resposta das culturas, sem a necessidade da construção de casas-de-vegetação e custos de cultivo. $O$ teste das inúmeras variáveis que influenciam no sistema praticamente impossibilitaria o seu estudo em campo. Outra característica é o pequeno tempo exigido para o processamento. Odum (1983) cita outras razões para a construção de modelos: a descrição simplificada pode direcionar para estudos mais detalhados; previsão de mudanças dinâmicas ao longo do tempo; mesmo o fracasso de um modelo seria útil, pois salientaria falhas nas premissas conceituais do sistema. Outras vantagens citadas por Jones (1994) seria a possibilidade de prever comportamento sob condições não testadas e a otimização do sistema.

No Brasil existem inúmeros trabalhos tratando do microclima em casasde-vegetação, mas que se restringem principalmente à caracterização de elementos como temperatura e umidade relativa do ar, transmissividade e radiação solar interna, e ao estudo do efeito da cobertura sobre estes. Trabalhos compreendendo uma interação mais complexa, como o emprego de modelos, ainda são escassos no Brasil, comparado com países de maior tradição no uso de casas-de-vegetação como Holanda, Israel, Inglaterra, França e Espanha. $O$ pouco que se tem visto restringe-se à aplicação de softwares de controle ambiental empregados em casas-de-vegetação e desenvolvidos em outros países com maior domínio nesta tecnologia. 
A literatura mostra vários trabalhos enfocando o desenvolvimento e uso de modelos para casas-de-vegetação, em sua maioria, baseados na subdivisão do sistema e elaboração e solução de equações de balanço de energia e de massa (principalmente do vapor d'água) (Takami \& Uchijima, 1977; Kindelan, 1980; Boulard \& Baile, 1993; Sbita et al., 1998). Como exemplos de subsistemas, citam-se principalmente $\mathrm{O}$ ar na estufa, a cobertura, a cultura e 0 solo. Para o ar, a equação de balanço de energia poderia ser formulada da seguinte forma:

$$
R n \cong H_{a r}+P_{c}+P_{v}+L E+G \quad\left(\mathrm{MJ} \cdot \mathrm{m}^{-2} \cdot \mathrm{dia}^{-1}\right)
$$

em que:

- Rn, saldo de radiação na casa-de-vegetação;

- $H_{a r}$, fluxo convectivo de calor sensivel (variação da temperatura do ar);

- $\quad P_{c}$, perdas por condução através da cobertura plástica;

- $P_{v}$, perdas calor sensível através da ventilação;

- LE, fluxo de calor latente (evapotranspiração);

- G, fluxo de energia para o solo.

Nesta expressão, foram negligenciados os fluxos de energia para a fotossintese e respiração, e para o aquecimento da estrutura da construção, considerando que são pequenos em relação aos outros fluxos.

Outras abordagens podem ser adotadas, como $\circ$ uso de técnicas de identificação de sistema (Cunha et al., 1998), em que um modelo matemático é ajustado a partir dos dados de entrada e saída. Entretanto, como os parâmetros mudam continuamente com a mudança das condições da estufa, é necessária a aquisição de dados e identificação dos parâmetros em tempo real. 
Nielsen \& Madsen (1998) desenvolveram um modelo linear estocástico, que se baseia na linearização das equações e determinação de seus parâmetros através de métodos estatísticos, e alcançaram estimativas de temperatura do ar com bom nível de confiança.

Como se trata de uma simplificação do sistema, uma etapa importante no desenvolvimento de modelos é a sua validação e teste. Modelos desenvolvidos por Jones et al. (1990), Yang et al. (1990), Fuller et al. (1987), Navas et al. (1998) mostraram ótimas correlações entre elementos climáticos simulados e medidos em estufa. Mas, por exigirem determinações de coeficientes locais e, em muitos casos, o uso de submodelos desenvolvidos para a condição de aplicação, ocorre uma restrição na aplicação destes modelos em outras localidades e mesmo em casas-de-vegetação diferentes. Isso aumenta a importância de estudos de modelagem específicos para cada componente do sistema, a exemplo de Seginer et al. (1988) e Feuilloley \& Issanchou (1996) para perdas de calor através da cobertura; Silva \& Rosa (1987), com balanço de ondas longas; Kittas et al. (1997), Boulard et al. (1996) e Seginer (1997), com ventilação; Critten (1983), com transmissividade da cobertura a radiação solar; Jolliet \& Bailey (1992) e Jolliet (1994), com evapotranspiração; e outros.

Atualmente, a sofisticação nos equipamentos de controle ambiental em casa-de-vegetação permite que grande parte das variáveis climáticas seja ajustada. Segundo Bailey \& Day (1999), devido ao alto valor de muitas culturas sob casas-de-vegetação, torna-se viável o investimento em sistemas de controle mais precisos, mas é exigido também o desenvolvimento de melhores modelos, tanto climáticos, como modelos de crescimento e rendimento das culturas associadas a rotinas de otimização. Citam-se como exemplos os trabalhos de loslovich \& Seginer (1996), loslovich \& Seginer (1998) e Jones et al. (1990) onde se procuravam as condições de temperatura e umidade relativa do ar e concentração de $\mathrm{CO}_{2}$ para a maximização do lucro na cultura do tomateiro. 


\section{MATERIAL E MÉTODOS}

\subsection{DesenVolvimento do MOdelo ESTUfA}

O modelo ESTUFA foi desenvolvido considerando uma casa-devegetação em arco simples (Figura 1), entretanto tendo em vista a generalidade dos coeficientes de entrada, é possivel a sua aplicação em outros tipos como capela, túnel baixo e casas-de-vegetação geminadas e múltiplos arcos, atendendo as limitações impostas pelo modelo.

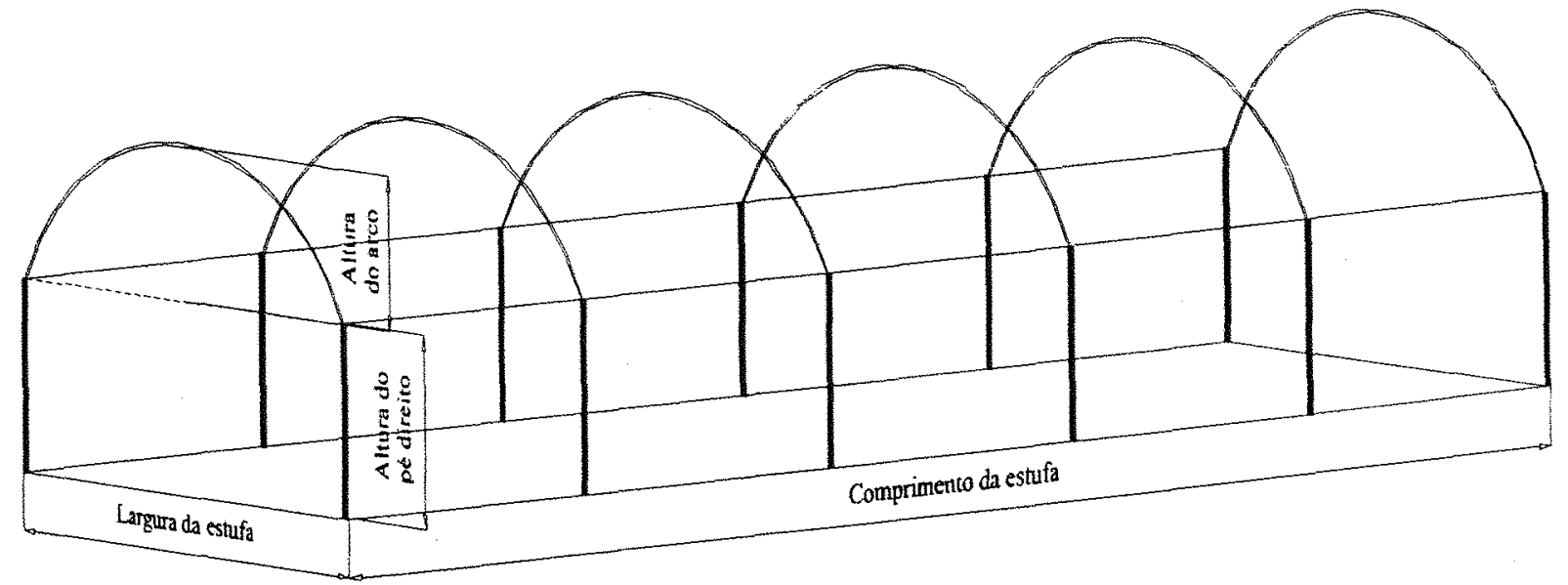

Figura 1. Esquema geral da casa-de-vegetação utilizada no modelo. 


\subsubsection{Transmissão da radiação através da cobertura}

Tendo-se as transmissividades do material de cobertura, a radiação no interior da casa-de-vegetação pode ser estimada com as equações (1) e (2), respectivamente, para as radiações de onda curta e onda longa.

$$
\begin{gathered}
R g i=R g \cdot \tau_{O C c} \\
R_{\text {OLi }}=R_{\text {OLex }} \cdot \tau_{O L c}
\end{gathered}
$$

em que:

$R g i$, radiação solar no interior da casa-de-vegetação, $\mathrm{W} \mathrm{m}^{-2}$;

$R g$, radiação solar global fora da casa-de-vegetação, $\mathrm{W} \mathrm{m}^{-2}$;

$R_{O L i}$, radiação de onda longa transmitida pela cobertura, $\mathrm{W} \mathrm{m}^{-2}$;

$R_{\text {LLex, }}$ radiação de onda longa fora da casa-de-vegetação, $\mathrm{W} \mathrm{m}^{-2}$;

$\tau_{O C_{c}}$, transmissividade da cobertura à radiação de onda curta;

$\tau_{O L c}$, transmissividade da cobertura à radiação de onda longa.

Foi considerado um valor médio de transmissividade ao longo do dia, negligenciando variações geradas pela mudança do ângulo de incidência com a cobertura, sombreamento provocado por estruturas na casa-de-vegetação e condensação na superfície do plástico. Durante o início e o final da tarde, quando a transmissividade é menor, a menor entrada de radiação é parcialmente compensada pela entrada de luz nas laterais verticais, o que poderia reduzir em parte os erros gerados por essa abordagem.

A radiação de onda longa externa pode ser estimada através da lei de Stefan-Boltzmann a partir da temperatura do ar externa. 


$$
R_{\text {OLex }}=\varepsilon_{e} \cdot \sigma \cdot T e^{4}
$$

em que:

- $\varepsilon_{e}$, emissividade da atmosfera;

- $\sigma$, constante de Stefan-Boltzmann, igual a 5,6697 $\times 10^{-8} \mathrm{~W} \mathrm{~m}^{-2} \mathrm{~K}^{-4}$;

- Te, temperatura do ar externo, $\mathrm{K}$.

$A$ eq. (3) não considera o efeito da nebulosidade sobre a radiação emitida pela atmosfera estando numa condição de céu sempre limpo.

\subsubsection{Calor proveniente da cobertura}

Dependendo do tipo de material usado, idade, acúmulo de poeira e ocorrência de condensação, mais ou menos radiação é absorvida pela cobertura da casa-de-vegetação. Considerando a pequena espessura dos filmes plásticos, a temperatura deste se encontra próxima da média das temperaturas interna e externa, sem grandes variações em curto espaço de tempo. Desta forma, pode-se estimar que a radiação absorvida pela cobertura é igual a radiação emitida mais o fluxo convectivo e condutivo de calor para o ar, sendo, aproximadamente, metade para o exterior e metade para o interior da casa-de-vegetação.

No presente trabalho a radiação absorvida pela cobertura foi composta por:

- radiação de onda curta externa: $R g \cdot \alpha_{O{ }_{O c}}$

- radiação de onda curta transmitida pelo dossel e refletida pelo solo: $R g i \cdot T d^{2} \cdot r_{O C S} \cdot \alpha_{O C C}$ 
- radiação de onda curta refletida pelo dossel: $R g i \cdot r_{O C d} \cdot \alpha_{O C c}$

- radiação de onda longa do ambiente externo: $R_{O L e x} \cdot \alpha_{O L c}$

- radiação de onda longa emitida pelo dossel: $R_{O L d} \cdot \alpha_{O L c}$

- radiação de onda longa emitida pelo solo e transmitida pelo dossel: $R_{O L s} \cdot T d \cdot \alpha_{O L c}$

em que $\alpha_{O C_{c}}$ e $\alpha_{O L c}$ são as absortâncias da cobertura às radiações de onda curta e onda longa, respectivamente; $r_{O c s}$ e $r_{O c d}$, as refletâncias à radiação de onda curta do solo e do dossel, respectivamente; $R_{O L d}$ e $R_{O L s}$, são as radiações de onda longa emitidas pelo dossel e solo, respectivamente; e $T d$, é a transmissibilidade do dossel calculado pela equação (4).

$$
T d=e^{-K \cdot I A F}
$$

em que

- $\quad T d$, transmissibilidade do dossel;

- $K$, coeficiente de extinção do dossel;

- $I A F$, indice de área foliar, $\mathrm{m}^{2} \mathrm{~m}^{-2}$.

O coeficiente de extinção, $K$, é função do ângulo de incidência da radiação e do tipo de radiação (difusa ou direta). No presente modelo, $K$ foi considerado constante, representando um valor médio para toda radiação incidente sobre a cultura ao longo do dia.

A refletância do dossel da cultura à radiação de onda curta como um todo, $r_{O C d}$, foi calculado pela eq. (5). Detalhes sobre a sua dedução podem ser vistos em Thormley \& Johnson (1990). 


$$
r_{O C d}=\left(\frac{r_{O C f}}{1-\tau_{O C f}}\right) \cdot\left(1-e^{-K \cdot L A F}\right)
$$

em que:

- $\quad r_{\text {oç }}$, refletância da folha à radiação de onda curta;

- $\tau_{\text {ocf }}$, transmissividade da folha à radiação de onda curta.

Assumiu-se que tanto a refletância quanto a transmissibilidade do dossel independem se a direção da radiação é de cima para baixo ou de baixo para cima. Muitas plantas tendem a ter uma reflexão maior na parte inferior da folha do que na superior.

A radiação emitida pela cobertura, $R_{O L p}$, é obtida com a equação de Stefan-Boltzmann:

$$
R_{O L p}=\varepsilon_{p} \cdot \sigma \cdot\left(\frac{T e+T i}{2}\right)^{4}
$$

em que:

- $\varepsilon_{p}$, emissividade do material de cobertura da casa-de-vegetação;

- Te, temperatura do ar no exterior da casa-de-vegetação, $\mathrm{K}$;

- Ti, temperatura do ar no interior da casa-de-vegetação, K.

A radiação de onda longa total proveniente da cobertura, $R_{O L_{c}}$, é a soma da radiação de onda longa externa $\left(R_{\text {OLex }}\right)$ transmitida e a radiação emitida, $R_{O L p}$ (eq. (7)). Nesta equação não estão incorporadas as radiações refletidas de 
retorna para o interior da casa-de-vegetação, que foram embutidas em outras expressões.

$$
R_{O L c}=R_{O L i}+R_{O L p}
$$

O restante da radiação absorvida é convertida em calor convectivo e condutivo. Considerando que aproximadamente metade vai para o ambiente externo e metade para o interior da casa-de-vegetação, e fazendo as devidas simplificações, o calor sensivel da cobertura para o ar da casa-de-vegetação, $H p$, é obtido pela expressão:

$H p=\frac{\alpha_{O C c}\left(R g+R g i \cdot T d^{2} \cdot r_{O C s}+R g i \cdot r_{O C d}\right)+\alpha_{O L c}\left(R_{O L e x}+R_{O L d}+R_{O L s} \cdot T d\right)}{2}-R_{O L p}$

\subsubsection{Balanço de energia no dossel}

De forma simples, o balanço de energia no dossel da cultura pode ser descrito pela expressão:

$$
B O L_{d}+B O C_{d}-L-H_{d a r} \cong 0
$$

em que:

- $B O L_{d}$, balanço de onda longa no dossel, $\mathrm{W} \mathrm{m}^{-2}$;

- $B O C_{d}$, balanço de onda curta no dossel, $\mathrm{W} \mathrm{m}^{-2}$;

- $\quad H_{d a r}$, calor sensivel do dossel para o ar, $\mathrm{W} \mathrm{m}^{-2}$;

- $\quad L$, calor latente de transpiração, $\mathrm{W} \mathrm{m}^{-2}$. 
$\mathrm{Na}$ eq. (9) foi negligenciado o fluxo de energia para o aquecimento do dossel. Tal pressuposição pode ser aplicada quando a massa da cultura é pequena e não existem grandes variações nos fluxos de energia (radiação solar, radiação de onda longa, fluxo de calor sensível) permitindo que o dossel se mantenha, relativamente, em equilíbrio. Assim, pode ser assumida a condição de equilíbrio dinâmico do sistema representado na eq. (9).

A Figura 2 mostra o caminhamento da radiação de onda longa e onda curta empregada no modelo.

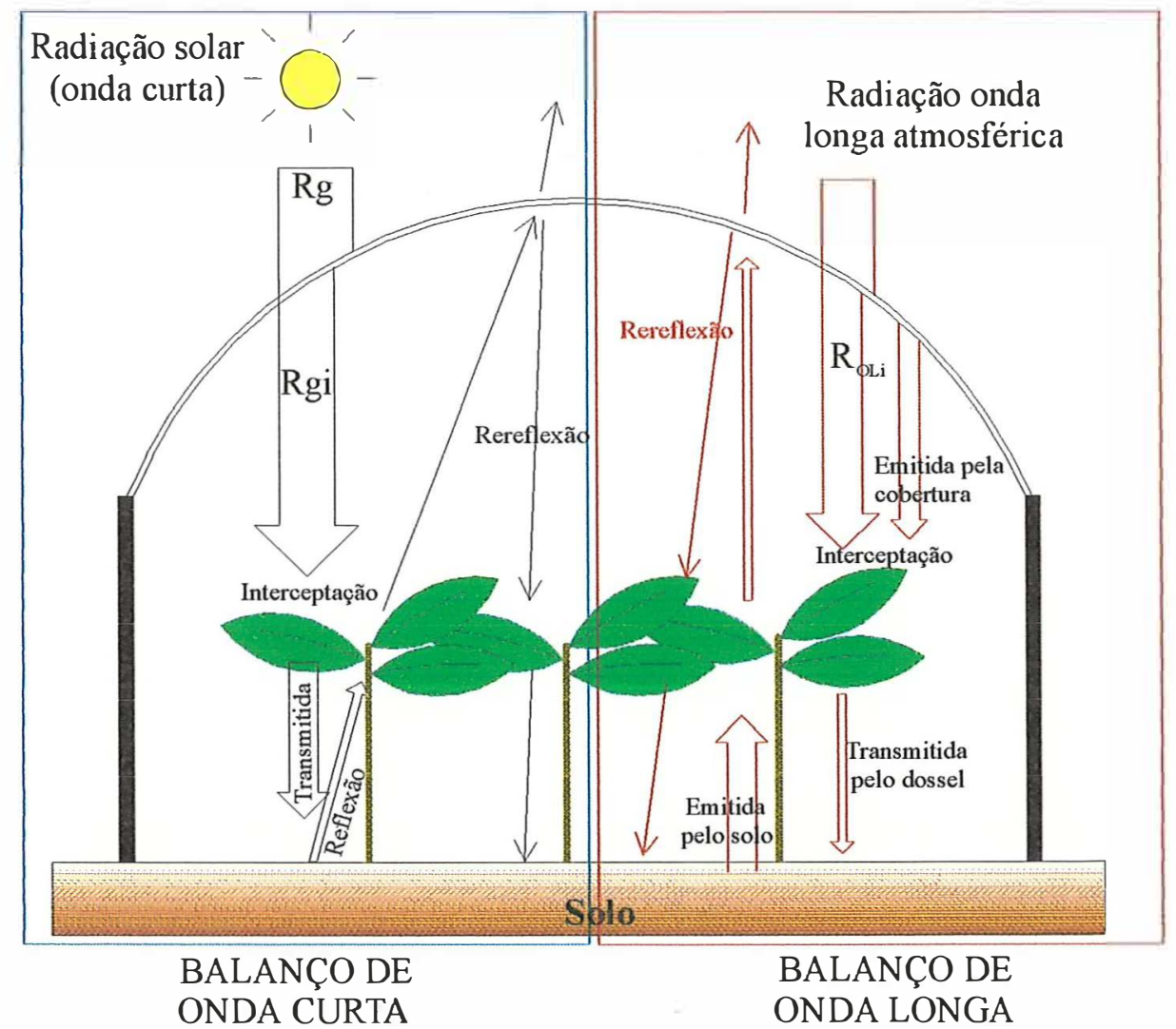

Figura 2. Esquema do balanço de radiação de onda longa e onda curta da casa-de-vegetação.

No balanço de onda longa do dossel, $B O L_{d}$, foram tomados os seguintes componentes: 
- radiação de onda longa total proveniente da cobertura e interceptada (absorvida) pelo dossel: $R_{O L c} \cdot(1-T d)$;

- radiação de onda longa emitida pelo solo e interceptada pelo dossel: $R_{\text {OLs }} \cdot(1-T d)$;

- radiação de onda longa emitida pelo dossel pelas partes superior e inferior: $2 \cdot R_{O L d}$;

- radiação emitida pelo dossel, refletida pela cobertura e interceptada pelo dossel: $R_{O L d} \cdot r_{O L c} \cdot(1-T d)$;

- radiação emitida pelo solo, transmitida pelo dossel, refletida pela cobertura e interceptada pelo dossel: $R_{O L S} \cdot T d \cdot r_{O L C} \cdot(1-T d)$.

Aqui considerou-se que toda a radiação de onda longa interceptada pelo dossel é absorvida.

Somando todos os componentes e fazendo as devidas simplificações, chega-se na eq. (10).

$$
B O L_{d} \cong\left(1-T_{d}\right) \cdot\left[R_{O L c}+R_{O L s}+R_{O L d}\left(r_{O L c}-2\right)+\left(R_{O L s} \cdot T_{d} \cdot r_{O L c}\right)\right]
$$

em que:

- $\quad T_{d}$, transmissibilidade do dossel;

- $R_{O L c}$ radiação de onda longa proveniente da cobertura, $\mathrm{W} \mathrm{m}^{-2}$;

- $R_{O L s}$, radiação de onda longa emitida pelo solo, $\mathrm{W} \mathrm{m}^{-2}$;

- $R_{O L d}$, radiação de onda longa emitida pelo dossel da cultura, $\mathrm{W} \mathrm{m}^{-2}$;

- $\quad r_{O L c}$, refletância da cobertura da casa-de-vegetação á radiação de onda longa. 
Na expressão (10) levou-se em conta que a radiação emitida pelo solo e pelo dossel sofrem uma reflexão na cobertura da casa-de-vegetação e retornam para o sistema. A contribuição de múltiplas reflexões de ordem maior que um é muito pequena, sendo por isso negligenciada nesta equação.

Para o cálculo da radiação de onda longa emitida pelo dossel é necessário se conhecer a temperatura do dossel. Em um sistema relativamente em equilíbrio, a temperatura da cultura está próxima da temperatura do ar. Isto é verificado no trabalho de Jolliet \& Bailey (1992) em que encontraram diferenças ao longo do dia entre $+0,8$ e $-0,3^{\circ} \mathrm{C}$ entre o dossel e 0 ar. Desta forma a radiação emitida pelo dossel pode ser estimada pela eq. (6), em que a temperatura do ar foi usada como uma aproximação da temperatura do dossel.

$$
R_{\text {OLd }}=\left(1-T_{d}\right) \cdot \varepsilon_{d} \cdot \sigma \cdot T i^{4}
$$

em que:

- $\varepsilon_{d}$, emissividade do dossel da cultura;

- $\quad T i$, temperatura do ar no interior da casa-de-vegetação, $\mathrm{K}$.

A primeira parte da equação, $\left(1-T_{d}\right)$, é uma correção para um dossel parcialmente fechado. Em uma cultura nos estágios iniciais, a área de emissão do dossel é menor que a área de solo. Como $T d$ é a fração do solo iluminado pela radiação solar, pode-se considerar que $\left(1-T_{d}\right)$ é aproximadamente a fração coberta pelo dossel. A radiação emitida real é o produto da fração coberta e a emissão do dossel em cobertura total, o que resulta na eq. (11).

Igualmente, a radiação de onda longa emitida pelo solo, $R_{O L s}$, é calculada através da equação de Stefan-Boltzmann (eq. (12)). A temperatura do solo $(T s)$ é fornecida pelo balanço de energia no solo e pelo submodelo de fluxo de calor no solo, abordado adiante.

$$
R_{O L s}=\varepsilon_{s} \cdot \sigma \cdot T s^{4}
$$

em que:

- $\varepsilon_{s}$, emissividade do solo; 
- $\quad T s$, temperatura na superfície do solo, $\mathrm{K}$.

No balanço de onda curta no dossel, foram computados:

- radiação solar interna à casa-de-vegetação (Rgi) absorvida pelo dossel: $R g i \cdot\left(1-T d-r_{O C d}\right)$;

- radiação solar interna transmitida pelo dossel, refletida pelo solo e absorvida pela cultura: $\mathrm{Rgi} \cdot \mathrm{Td} \cdot \mathrm{r}_{O C s} \cdot\left(1-\mathrm{Td}-\mathrm{r}_{O C d}\right)$;

- radiação solar refletida pelo solo, transmitida pelo dossel, refletida pela cobertura da casa-de-vegetação e absorvida pela cultura: $R g i \cdot T d^{2} \cdot r_{O C s} \cdot\left(1-T d-r_{O C d}\right)$;

- radiação solar refletida pelo dossel, refletido pela cobertura e absorvida pelo dossel: $R g i \cdot r_{O C d} \cdot r_{O C c} \cdot\left(1-T d-r_{O C d}\right)$.

Somando-se os componentes e simplificando a equação, tem-se:

$$
B O C_{d} \cong R g i \cdot\left(1-T_{d}-r_{O C d}\right) \cdot\left[1+T_{d} \cdot r_{O C s} \cdot\left(1+T_{d} \cdot r_{O C c}\right)-r_{O C d} \cdot r_{O C c}\right]
$$

em que:

- Rgi, radiação solar no interior da casa-de-vegetação;

- $r_{O C s}$, refletância do solo a radiação de onda curta.

Também nesta equação foi considerado que a radiação refletida pela cultura e pelo solo sofre uma reflexão na cobertura da casa-de-vegetação, retornando ao sistema.

O fluxo de energia para a transpiração (calor latente) foi calculado por uma simplificação da equação de Penman-Monteith, testada por Jolliet \& Bailey (1992) que mostrou bons resultados para a cultura do tomate em estufa. A equação tem a seguinte forma: 


$$
L \cong a \cdot \operatorname{Rgi}+b \cdot \Delta e
$$

em que:

- $\quad L$, fluxo de energia para a transpiração, $W \mathrm{~m}^{-2}$;

- $\Delta e$, déficit de pressão de vapor, $\mathrm{kPa}$

- $a$ e $b$, coeficientes empíricos;

Os coeficientes $a$ e $b$ variam com a fase da cultura e com a época do ano, fazendo com que o modelo seja aplicável apenas para determinada fase, época do ano e configuração (Jolliet, 1994). Para os fins do trabalho, esta aproximação foi utilizada na falta de modelos de evapotranspiração mais adequados para casas-de-vegetação.

Foi considerado que a umidade do solo sempre permanece próxima da capacidade de campo, ficando a evapotranspiração da cultura igual a evapotranspiração potencial. A exigência de irrigação em casas-de-vegetação e um bom manejo permite a aplicação dessa condição na maior parte dos casos.

A taxa de transpiração da cultura, $E, \mathrm{~kg} \mathrm{~m}^{-2} \mathrm{~s}^{-1}$, pode ser obtida pela divisão de $L$ pelo calor latente de vaporização, $\lambda, \mathrm{J} \mathrm{kg}^{-1}$ (eq. (15)). Para água a $20^{\circ} \mathrm{C}$, tem-se $\lambda=2,45 \times 10^{6} \mathrm{~J} \mathrm{~kg}^{-1}$, sendo considerado como constante, visto que este é função fraca da temperatura dentro das condições naturais de evaporação (Pereira et al., 1997).

$$
E=\frac{L}{\lambda}
$$

Por diferença, através da eq. (9), obtém-se o calor sensivel fornecido pelo dossel para o ar, $H_{d a r}$, e que representa parte do aquecimento no interior da casa-de-vegetação. Aqui admite-se que o dossel reage instantaneamente 
aos fluxos de energia e está em equilibrio constante com o ar da casa-devegetação, ou seja, o fluxo de energia para o aquecimento da massa do dossel é aproximadamente nulo.

\subsubsection{Balanço de energia no solo}

De forma análoga, o balanço de energia na superfície do solo foi calculado computando-se o balanço de onda curta, balanço de onda longa e calor sensivel por convecção. Por diferença é obtido o fluxo de calor para o solo.

$$
\begin{aligned}
& B O L_{s}+B O C_{s}-H_{c o n v}-G \cong 0 \\
& \text { ou } \\
& G \cong B O L_{s}+B O C_{s}-H_{c o n v}
\end{aligned}
$$

em que:

- $B O L_{s}$, balanço de onda longa na superfície do solo, $\mathrm{W} \mathrm{m}^{-2}$;

- $B O C_{s}$, Balanço de onda curta na superfície do solo, $\mathrm{W} \mathrm{m}^{-2}$;

- $\quad H_{\text {conv }}$, calor sensível por convecção do solo para o ar, $\mathrm{W} \mathrm{m}^{-2}$;

- $G$, fluxo de energia para o solo, $\mathrm{W} \mathrm{m}^{-2}$.

A evaporação da água do solo foi negligenciada neste balanço. Em uma cultura em pleno desenvolvimento, esta tem pequena participação na evapotranspiração total. Além disso, é pratica comum o uso de coberturas plásticas ou orgânicas no solo ("mulching") para melhorar as condições do solo e reduzir o excesso de umidade no interior da casa-de-vegetação, o que praticamente elimina a evaporação do solo. 
A radiação de onda longa que atinge o solo provém principalmente de duas fontes: (1) da cobertura, $R_{O L c}$, formada pela radiação externa transmitida e a radiação emitida, que atinge o solo após ter sido transmitida pelo dossel; (2) da radiação emitida pela parte inferior do dossel e atinge diretamente o solo. Também neste caso, foi computada a radiação emitida pelo dossel e solo, e refletida pela cobertura e assumiu-se que o solo absorve toda a radiação de onda longa. Cada componente foi representada pelas seguintes equações:

- radiação de onda longa no interior da casa-de-vegetação, transmitida pelo dossel e absorvida pelo solo: $R_{O L C} \cdot T d$;

- radiação de onda longa emitida pelo solo: $R_{\text {OLs }}$;

- radiação emitida pelo solo, transmitida pelo dossel, refletida pela cobertura, transmitida novamente pelo dossel e absorvida pelo solo: $R_{O L S} \cdot T d^{2} \cdot r_{O L c} ;$

- radiação de onda longa emitida pelo dossel (parte inferior) e absorvida pelo solo: $R_{\text {OLd }}$;

- radiação emitida pelo dossel (parte superior), refletida pela cobertura da casa-de-vegetação, transmitida pelo dossel e absorvida pelo solo: $R_{O L d} \cdot r_{O L c} \cdot T d$

Somando-se os componentes e simplificando a equação, obteve-se a expressão:

$$
B O L_{s} \cong T_{d}\left[R_{O L c}+r_{O L c} \cdot\left(R_{O L s} \cdot T_{d}+R_{O L d}\right)\right]+R_{O L d}-R_{O L s}
$$

Para o cálculo do balanço de onda curta do solo $\left(B O C_{s}\right)$ também se considerou que a radiação refletida pelo dossel e pelo solo sofre uma reflexão na cobertura da casa-de-vegetação. $O B O C_{s}$ foi composto por: 
- Radiação solar interna (Rgi) transmitida pelo dossel: $R g i \cdot T d \cdot\left(1-r_{O C s}\right)$;

- Rgi transmitida pelo dossel, refletida pelo solo, transmitida pelo dossel novamente, refletida pela cobertura, transmitida pelo dossel e absorvida pelo solo: $R g i \cdot \mathrm{Td}^{3} \cdot r_{O C S} \cdot r_{O C \cdot} \cdot\left(1-r_{O C S}\right)$;

- Rgi refletida pelo dossel,refletida pela cobertura, transmitida pelo dossel e absorvida pelo solo: $R g i \cdot r_{O C d} \cdot r_{O C c} \cdot T d \cdot\left(1-r_{O C S}\right)$;

- Rgi transmitida pelo dossel, refletida pelo solo, refletido pelo dossel (parte inferior) e absorvido pelo solo: $R g i \cdot T d \cdot r_{O C s} \cdot r_{O C d} \cdot\left(1-r_{O C s}\right)$.

Somando-se os componentes e simplificando a equação, tem-se:

$$
B O C_{s} \cong R g i \cdot T_{d} \cdot\left(1-r_{O C s}\right) \cdot\left[1+\left(T_{d}{ }^{2} \cdot r_{O C s} \cdot r_{O C c}\right)+r_{O C d} \cdot\left(r_{O C c}+r_{O C s}\right)\right]
$$

O fluxo de energia por calor convectivo pode ser calculado pela eq. (19) (Takakura et al., 1971; Tarara \& Ham, 1999). Para o modelo, foi considerado que o calor sensivel, composto pelos fluxos convectivo (movimento de massa) e condutivo (transferência entre partículas), é representado exclusivamente pelo componente convectivo. Proporcionalmente este constitui a quase totalidade do calor sensivel transferido para o ar.

$$
H_{\text {conv }} \cong h s \cdot(T s-T i)
$$

em que:

$H_{\text {conv }}$, calor sensivel convectivo, $\mathrm{W} \mathrm{m}^{-2}$;

$h s$, coeficiente de transferência de calor sensivel, por convecção, do solo para o ar, $\mathrm{W} \mathrm{m}^{-2} \mathrm{~K}^{-1}$. 


\subsubsection{Fluxo de energia no solo}

No cálculo do fluxo de energia ao longo do perfil do solo foi utilizado um submodelo onde o solo é considerado um meio homogêneo, sem variações espaciais e temporais na condutividade térmica $\left(K_{T}, \mathrm{~J} \mathrm{~m}^{-1} \mathrm{~s}^{-1} \mathrm{~K}^{-1}\right)$ e capacidade térmica $\left(C_{T}, \mathrm{~J} \mathrm{~m}^{-3} \mathrm{~K}^{-1}\right)$. O fluxo de energia foi baseada na equação de Fourrier (eq.(20)) e solucionado numericamente. Para isso, o perfil de solo foi subdividido em várias camadas de espessura $\Delta z$, fazendo o diferencial de temperatura, $d T$, ser aproximadamente igual a diferença de temperatura entre duas camadas subseqüentes. Assim a eq. (20) pode ser aproximada para a eq. (21).

$$
q z=-K_{T} \frac{d T}{d z}
$$

em que:

- $q z$, é a densidade de fluxo de energia no solo, $\mathrm{W} \mathrm{m}^{-2}$;

- $d T$, é o diferencial de temperatura ao longo do perfil, $\mathrm{K}$.

$$
q z_{n}=-K_{T} \frac{T_{n+1}-T_{n}}{\Delta z}
$$

em que:

- $q z_{n}$, densidade de fluxo de calor na camada $\mathrm{n}$;

- $T_{n+1}$ e $T_{n}$, temperatura do solo nas camadas $\mathrm{n}$ e $\mathrm{n}+1$;

Aplicado em um pequeno intervalo de tempo, $\Delta t$, a variação da temperatura pode ser estimada pela equação da continuidade (eq. (22)).

$$
\frac{d q z}{d z}=C_{T} \frac{d T}{d t}
$$


em que:

- $\quad d q z$, diferencial da densidade de fluxo de energia no solo, $\mathrm{W} \mathrm{m}^{-2}$;

- $d t$, diferencial de tempo, s;

- $\frac{d q z}{d z}$, variação do fluxo de energia ao longo do perfil do solo;

- $\frac{d T}{d t}$, variação da temperatura do solo ao longo do tempo.

Fazendo $d t \cong \Delta t ; d z \cong \Delta z ; d q z \cong \Delta q z=q z_{n+1}-q z_{n} ;$ e $d T \cong \Delta T_{n . t}$ temos:

$$
\begin{array}{ll}
\frac{\Delta q z}{\Delta z}=C_{T} \frac{\Delta T_{n, t}}{\Delta t} \quad \text { ou } & \\
\Delta T_{n . t}=\frac{\Delta q z \cdot \Delta t}{\Delta z \cdot C_{T}} \quad \text { ou } & \\
& \Delta T_{n, t}=\frac{\left(q z_{n+1}-q z_{n}\right) \cdot \Delta t}{\Delta z \cdot C_{T}} .
\end{array}
$$

sendo $\Delta T_{n, t}$ a variação de temperatura na camada $n$ e no tempo $t$. Assim a nova temperatura da camada $n, T_{n . t+1}$, para o próximo passo de tempo será:

$$
T_{n, t+1}=T_{n, t}+\Delta T_{n, t}
$$

A rotina é realizada continuamente ao longo do processamento do modelo, para cada camada do solo, em cada passo de tempo. Apenas na primeira camada o fluxo de energia é fornecido por $G$, calculado pela eq.(16). Também é necessária a atribuição de uma temperatura inicial. À medida que transcorre a simulação, o perfil de temperatura no solo tende a se equilibrar 
com as condições de contorno do modelo, que ocorre rapidamente devido ao pequeno passo de tempo utilizado ( 2 segundos).

\subsubsection{Perda de calor através da cobertura plástica.}

A eq. (25) foi usada para estimar as perdas de energia por radiação, condução e convecção através da cobertura da casa-de-vegetação (telhado e laterais) (Boulard \& Baille, 1993; Hanan, 1998; ).

$$
H_{c}=K c \cdot(T i-T e) \frac{A c}{A s}
$$

em que:

- $H_{c}$, perdas de energia através da cobertura, W. $\mathrm{m}^{-2}$;

- Kc, coeficiente geral de perda de calor da cobertura, W. $\mathrm{m}^{-2} \cdot \mathrm{K}^{-1}$;

- $\quad T i$, temperatura do ar no interior a casa-de-vegetação, $\mathrm{K}$;

- Te, temperatura do ar externo, $\mathrm{K}$;

- $A c$, superfície com plástico da casa-de-vegetação, incluindo laterais e telhado, $\mathrm{m}^{2}$;

- $A s$, área de solo coberta pela casa-de-vegetação, $\mathrm{m}^{2}$;

Como a eq. (25) integra os componentes radiativo, condutivo e convectivos, o coeficiente $K c$ depende não só do tipo de material, mas também das condições climáticas externas (céu coberto ou claro, velocidade do vento), como se tem demonstrado nos trabalhos de Nijskens et al. (1984), Zamir et al. (1984), Boulard \& Baille (1993) e Hanan (1998). No presente trabalho, foi utilizada a eq. (26), adotado por Boulard \& Baille (1993), em que Kc é uma função linear da velocidade do vento externa $\left(U, \mathrm{~m} \mathrm{~s}^{-1}\right)$. 


$$
K c=A+B \cdot U
$$

$A$ e $B$ são coeficientes empíricos dependentes do material de cobertura. Para o PEBD, $A$ e $B$ assumem os valores típicos de 6 e 0,5 , respectivamente.

\subsubsection{Perda de calor através da ventilação}

A perda de calor sensivel através da ventilação, $H_{\text {vent }}$, W. $\mathrm{m}^{-2}$, diretamente proporcinal a diferença de temperatura entre $\mathrm{o}$ ambiente interno e externo (Boulard \& Baille, 1993) e obtido pela expressão:

$$
H_{\text {vent }}=h v \cdot(T i-T e)
$$

em que $h v, W \cdot \mathrm{m}^{-2} \cdot \mathrm{K}^{-1}$, é o coeficiente de perda de calor pela ventilação, proporcional a taxa de removação do ar interno e do volume da casa-devegetação, como se segue:

$$
h v=\frac{\rho_{a r} \cdot C p \cdot V o l \cdot N}{A s}
$$

em que:

- $\quad C p$, calor sensivel do ar, $\mathrm{J} . \mathrm{kg}^{-1} \cdot \mathrm{K}^{-1}$;

- $\rho_{a r}$, massa especifica do ar, kg.m

- Vol, volume da casa-de-vegetação, $\mathrm{m}^{3}$;

- $\quad N$, taxa de ventilação do ar da casa-de-vegetação, $\mathrm{s}^{-1}$;

A taxa de ventilação, $N$, ou taxa de renovação do ar da casa-devegetação representa quantos volumes, equivalente ao volume da casa-devegetação, são trocados por unidade de tempo. O produto de $\mathrm{Ne} \mathrm{Vol}$, resulta 
em uma taxa de ventilação em $\mathrm{m}^{3} \cdot \mathrm{s}^{-1}$. Pesquisas (Boulard \& Baille, 1993; Boulard et al., 1996; Kittas et al., 1997; Mistriotis et al., 1997) constataram que $N$ é diretamente proporcional a velocidade do vento externa e a área de aberturas, podendo ser estimada pela equação:

$$
N=\frac{A j \cdot A \cdot \sqrt{C w} \cdot U}{\mathrm{Vol} \cdot 2}+N o
$$

em que,

- $A j$, área de janelas ou abertura, $\mathrm{m}^{2}$;

- $\quad U$, velocidade do vento externa, $\mathrm{m}^{2}$;

- $A$, coeficiente de descarga;

- $C w$, coeficiente de efeito do vento;

- No, taxa de infiltração ou taxa de ventilação básica, $\mathrm{s}^{-1}$;

Em geral, a expressão $A \cdot \sqrt{C w}$ é computado como um coeficiente da equação, e que depende do tipo de casa-de-vegetação, área e formato das aberturas, disposição e da ocorrência de culturas (Boulard et al., 1997).

O coeficiente No representa a taxa de renovação de ar que ocorre quando não há vento ou quando todas as aberturas estiverem fechadas. Este movimento de ar é devido a fissuras na estrutura, má vedação e pela convecção do ar causado pelo aquecimento.

No presente modelo, $A \cdot \sqrt{C w}$ e No foram considerados constantes, assumindo os valores de 0,26 e $0,00236 \mathrm{~s}^{-1}$, respectivamente, obtidos no trabalho de Boulard et al. (1997) em estufas com abertura lateral.

Incorporando o manejo das cortinas, comumente feito em casas-devegetação, $A j$ pode ser dado pela expressão: 


$$
A j=P a b \cdot A T j
$$

em que $P a b$ é o percentual de abertura das janelas e $A T j$ é a área total de abertura, quando a casa-de-vegetação está totalamente aberta.

A área total de aberturas foi calculada como sendo a área das laterais no sentido longitudinal da casa-de-vegetação, ou seja, o fundo e a frente da casade-vegetação estão sempre fechados. Na rotina para resolução das equações foi implementado um manejo de cortinas, em que é possível indicar o horário e - percentual de abertura das cortinas. Foram programados dois horários de fechamento/abertura de cortinas, o que possibilita a simulação de abertura pela manhã e o fechamento durante a noite. Esta atividade é comumente realizada em cultivos protegidos para se evitar um resfriamento muito grande durante a noite, principalmente em dias frios de inverno e promover um melhor controle da temperatura durante $o$ dia.

\subsubsection{Energia disponível para o aquecimento do ar}

Diferente do solo, o ar da casa-de-vegetação foi considerado como um todo, sem subdivisões, fazendo com que todos os fluxos de energia reajam em todo o volume da casa-de-vegetação. Essa condição foi adotada pois os movimentos advectivos e convectivos tendem a movimentar $O$ ar da casa-devegetação, dificultando a determinação pontual da temperatura. Com isso a temperatura interna resultante do modelo representa aproximadamente a média das temperaturas no interior da casa-de-vegetação. Não foi levado em conta a massa da casa-de-vegetação, desprezando seu efeito como fonte ou dreno de calor.

O fluxo de energia para o aquecimento (ou resfriamento) do ar na casade-vegetação, Har, W.m-2 ${ }^{-2}$ é obtido pela eq.(31). 


$$
H a r \cong H_{c o n v}+H_{p}+H_{d a r}-H_{c}-H_{v e n t}
$$

Aplicando-se Har em um pequeno intervalo de tempo, $\Delta t$, obtém-se uma variação na temperatura do ar, $\Delta$ Tar, expressa pela eq.(32)

$$
\Delta \operatorname{Tar}=\frac{\operatorname{Har} \cdot A s \cdot \Delta t}{\rho_{a r} \cdot C p \cdot V o l}
$$

em que:

- As, área de solo da casa-de-vegetação, $\mathrm{m}^{-2}$;

- $\rho_{a r}$, massa específica do ar, $\mathrm{kg} \cdot \mathrm{m}^{-3}$;

- $\quad C p$, calor específico do ar à pressão constante, $\mathrm{J} \cdot \mathrm{kg}^{-1} \cdot \mathrm{K}^{-1}$;

- Vol, volume de ar da casa-de-vegetação, $\mathrm{m}^{3}$.

Os valores de massa específica, $\rho_{a r}$, e calor específico do ar $(C p)$ foram assumidos como sendo $1,129 \mathrm{~kg} \cdot \mathrm{m}^{-3}\left(20^{\circ} \mathrm{C}\right.$, a pressão de atmosférica de $\left.95 \mathrm{kPa}\right)$ e $1009,02 \mathrm{~J} \mathrm{~kg}^{-1} \cdot \mathrm{K}^{-1}$, respectivamente (Ometto, 1981). Considerou-se que não ocorrem grandes variações nesses valores dentro das condições estudas, podendo ser adotados como constantes. Sendo assim, a capacidade térmica, produto de $\rho_{a r}$ e $C p$, também não varia e assumiu o valor de $1139,18 \mathrm{~J} \cdot \mathrm{m}^{-3} \cdot \mathrm{K}^{-1}$.

O novo valor de temperatura para o próximo intervalo $\Delta t$ será:

$$
T i_{t+1}=T i_{t}+\Delta T a r
$$

em que

- $\quad T i_{t+1}$, temperatura do ar na casa-de-vegetação no passo de tempo $t$ $+1$

- $T i_{t}$, temperatura do ar no passo de tempo $t$. 


\subsubsection{Balanço de vapor d'água}

A equação do balanço de vapor d'água no interior da casa-de-vegetação pode ser visto a seguir:

$$
\frac{E \cdot A s}{V o l}-W_{a r}-W_{\text {vent }} \cong 0
$$

em que a primeira parte representa a contribuição da transpiração para a umidade do ar; $W_{a r}$ é o fluxo de vapor d'água para o ar da casa-de-vegetação, $\mathrm{kg} \cdot \mathrm{m}^{-3} \cdot \mathrm{s}^{-1}, W_{\text {vent }}$ é a perda de vapor d'água através da ventilação, $\mathrm{kg} \cdot \mathrm{m}^{-3} \cdot \mathrm{s}^{-1} \cdot W_{\text {vent }}$ é fornecido pela eq. (35), adaptado de Stanghellini \& de Jong (1995).

$$
W_{\text {vent }}=N \cdot(\rho i-\rho e)
$$

em que $\rho i$ e $\rho e$, são as umidades especificas, $\mathrm{kg} \cdot \mathrm{m}^{-3}$, do ar interno e externo, calculados em função da umidade relativa e temperatura do ar, de acordo com as equações (36), (37) e (38) (Pereira et al., 1997).

$$
\begin{gathered}
\rho=\frac{2,166 \cdot e_{a}}{T} \\
e_{a}=\frac{e_{s} \cdot U R}{100} \\
e_{s}=0,61 \cdot e^{\frac{17,27 \cdot T}{237 \cdot 3+T}}
\end{gathered}
$$

em que:

- $\rho$, umidade especifica do ar, kg.m-3;

- $e_{a}$, pressão atual do vapor, kPa; 
- $\quad e_{s}$, pressão de saturação do vapor, $\mathrm{kPa}$;

- UR, umidade relativa do ar, \%;

- $T$, temperatura do ar, ${ }^{\circ} \mathrm{C}$.

Por diferença é obtido War, fornecendo numericamente a variação da umidade do ar, dado pela eq. (39). Assim, o novo valor de umidade específica, $\rho i_{t+1}$, é calculado pela eq. (40). As umidades específicas acima da umidade de saturação foram igualadas a umidade de saturação. A partir deste valor é obtido o déficit de pressão de vapor e a umidade relativa do ar no interior da casa-devegetação.

$$
\begin{gathered}
\Delta \rho i=W_{a r} \cdot \Delta t \\
\rho i_{t+1}=\rho i_{t}+\Delta \rho i
\end{gathered}
$$

em que:

- $\Delta \rho i$, variação da umidade específica para o próximo passo de tempo, $\mathrm{kg} \mathrm{m}^{-3}$;

- $\Delta t$, passo de tempo, s;

- $\quad \rho i_{t+1}$, umidade específica para o passo de tempo $t+1$;

- $\rho i_{t}$, umidade específica para o passo de tempo t.

\subsubsection{Volume e área de cobertura da casa-de-vegetação}

Para facilitar os cálculos de volume e área de cobertura da casa-devegetação, a curvatura do teto foi ajustada para um segmento de arco de uma circunferência, de raio $R$, e ângulo do arco $\beta$ (Figura 3). Assim, os cálculos 
puderam ser efetuados tendo-se apenas os valores de largura, comprimento e altura do pé direito da casa-de-vegetação, altura do arco.

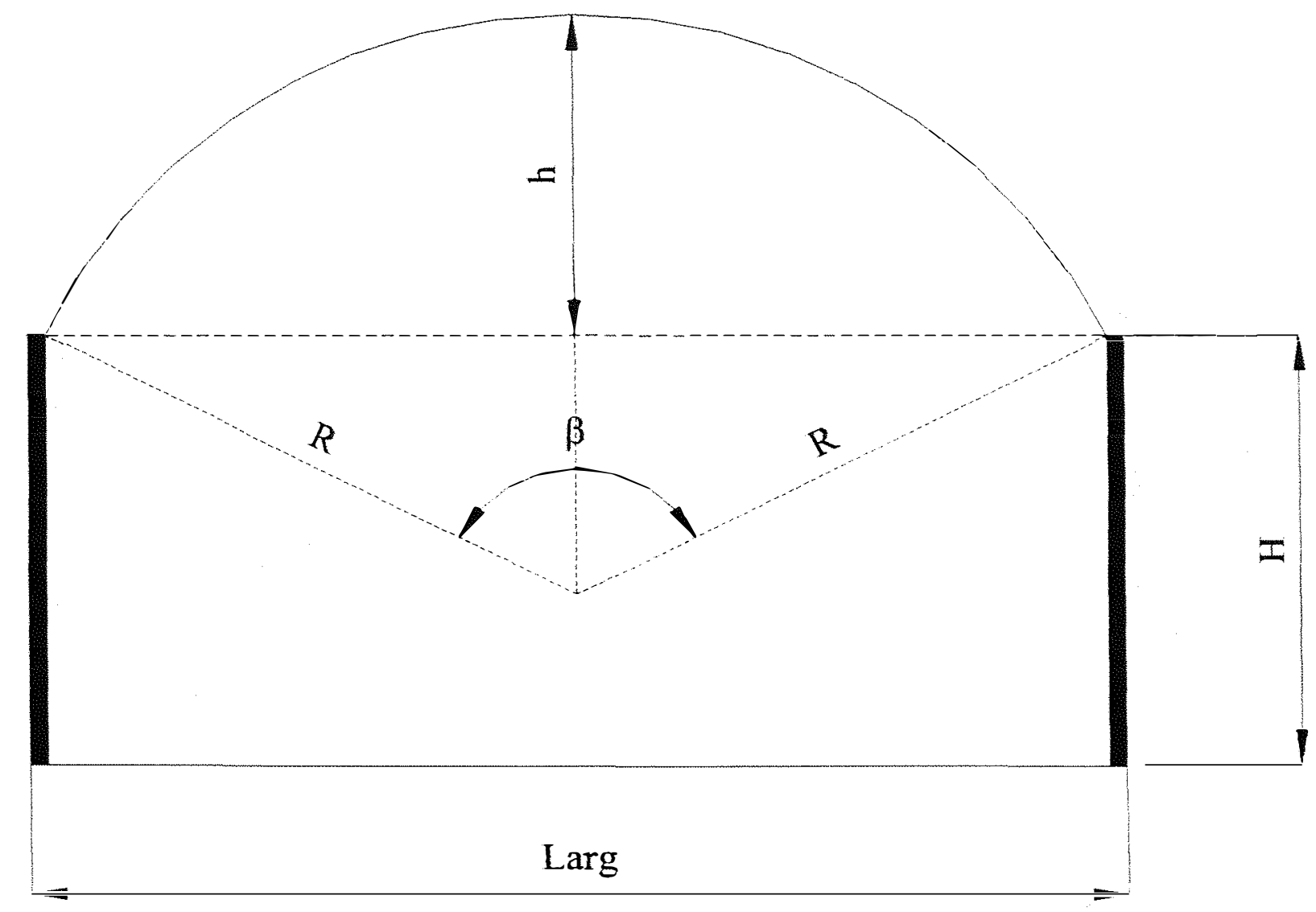

Figura 3. Esquema em corte da casa-de-vegetação.

$R$ e $\beta$ podem ser obtidos através das equações (41) e (42) deduzidas através de relações trigonométricas.

$$
\begin{gathered}
R=\frac{4 \cdot h^{2}+L \arg ^{2}}{8 \cdot h} \\
\beta=2 \cdot \operatorname{arcsen}\left(\frac{4 \cdot L \arg \cdot h}{4 \cdot h^{2}+L \arg { }^{2}}\right)
\end{gathered}
$$

em que: 
- R, raio da circunferência ajustada, m;

- $\quad \beta$, ângulo do arco, rad;

- $h$, altura do arco, m;

- Larg, largura da casa-de-vegetação, m;

O volume na região do arco, $V_{\text {arco }}$, é fornecido pela eq. (43)

$$
V_{\text {arco }}=\left[\frac{\beta \cdot R^{2}-L \arg \cdot(R-L \arg )}{2}\right] \cdot \operatorname{Comp}
$$

em que Comp é o comprimento da casa-de-vegetação.

Substituindo eq. (41) em (43) tem-se:

$$
\left.V_{\text {arco }}=\left[\beta \frac{\left(4 \cdot h^{2}+L \arg ^{2}\right.}{8 \cdot h}\right)^{2}+L \arg \cdot \frac{\left(4 \cdot h^{2}--L \arg ^{2}\right)}{8 \cdot h}\right] \frac{C o m p}{2} .
$$

O volume total da casa-de-vegetação é a soma do volume na região do arco e o volume da base da casa-de-vegetação:

$$
\mathrm{Vol}=V_{\text {arco }}+\operatorname{Comp} \cdot L \arg \cdot H
$$

em que:

- Vol, volume total da casa-de-vegetação, $\mathrm{m}^{3}$;

- $\quad H$, altura do pé direito, $\mathrm{m}$. 
A superfície total de cobertura da casa-de-vegetação, $A c$, é a soma da superfície na região do arco, $A_{\text {arco }}$, e a superfície de laterais, $A_{\text {laterais }}$, considerando o percentual de abertura das cortinas.

$$
A c=A_{\text {arco }}+A_{\text {laterais }}
$$

sendo:

$$
A_{\text {arco }}=2 \cdot A_{\text {arcoL }}+A_{\text {arcosup }}
$$

em que:

- $A_{\text {arcoL }}$, superfície coberta na extremidade da região do arco, $\mathrm{m}^{2}$;

- $A_{\text {arcosup }}$, superfície coberta na parte superior da região do arco, $\mathrm{m}^{2}$.

A área da extremidade na região do arco, ou seja, a frente e o fundo da casa-de-vegetação, é calculado pela eq. (48).

$$
A_{\text {arcoL }}=\frac{\beta \cdot R^{2}+L \arg \cdot(R-h)}{2}
$$

$A_{\text {arcosup }}$ é dado por:

$$
A_{\text {arcosup }}=R \cdot \beta \cdot \text { Comp }
$$

Somando-se (48) e (49), tem-se que:

$$
A_{\text {aroo }}=\beta \cdot R^{2}+L \arg \cdot(R-h)+R \cdot \beta \cdot \operatorname{Comp}
$$

Substituindo $R$ pela eq. (41) e fazendo as devidas simplificações chegase em: 


$$
A_{\text {arco }}=\left(\frac{4 \cdot h^{2}+L \mathrm{arg}^{2}}{8 \cdot h}\right) \cdot\left[\beta \cdot\left(\frac{\left.4 \cdot h^{2}+L \mathrm{arg}^{2}\right)}{8 \cdot h}-L \arg +\beta \cdot \operatorname{Comp}\right]+L \arg \cdot h\right.
$$

A área das laterais é dada pela eq. (51), baseado numa casa-devegetação em que a frente e $\circ$ fundo estão sempre fechados e com a possibilidade de abertura das cortinas laterais.

$$
A_{\text {lateras }}=2 \cdot H \cdot(P a b \cdot C o m p+L \mathrm{arg})
$$

em que

- $\quad H$, altura do pé direito, $\mathrm{m}$;

- Pab, percentual de abertura das cortinas/janela.

\subsection{RESOLUÇÃO DO MODELO ESTUFA}

A resolução das equações diferenciais foi realizado numericamente, adotando-se um passo de tempo, $\Delta t$, de 2 segundos. Nesse intervalo de tempo os fluxos podem ser considerados aproximadamente lineares em relação ao tempo e os gradientes de temperatura praticamente constantes. Para cada intervalo $\Delta t$ é calculado a variação de temperatura no ar, $\Delta T a r$, e no solo, e a variação de umidade do ar, $\Delta \rho i$, fornecendo as novas temperaturas no ar e no solo e a nova umidade do ar na casa-de-vegetação. Esses valores são usados no próximo passo de tempo, gerando novos gradiente de temperatura e umidade e assim sucessivamente.

No primeiro passo de tempo é necessária a atribuição de um valor inicial de temperatura do ar interna, umidade relativa e temperatura do solo. Após o início da simulação esses valores tendem a se estabilizar. 
O modelo foi implementado na forma de um programa, denominado "ESTUFA", compilado em linguagem de programação Delphi 3.0. O programa de simulação permite o uso de arquivos com dados externos de um dia e manipulação de todos os coeficientes das equações. Na Figura 4 está representado o fluxograma simplificado do programa desenvolvido. Os dados externos foram obtidos de estação meteorológica automática, com médias de intervalos de 15 minutos, dos elementos temperatura do ar, umidade relativa do ar, radiação solar e velocidade do vento. Como o intervalo de tempo dos dados de entrada (15 minutos) era diferente do passo de tempo do modelo (2 segundos), foi assumido que, dentro do intervalo de 15 minutos dos dados externos, todos os valores eram iguais a média registrada.

O programa gera um arquivo de saída, com dados em intervalos de 15 minutos, dos seguintes elementos:

- temperaturas interna e externa;

- umidades relativas interna e externa;

- temperatura na superfície do solo;

- radiação solar global interna e externa;

- fluxo de calor no solo;

- perdas de calor sensível pela ventilação;

- calor latente para transpiração;

- perdas de calor condutivo/convectivo através da cobertura;

- calor convectivo do solo para o ar na casa-de-vegetação;

- calor condutivo/convectivo do dossel para o ar;

- radiação de onda longa emitida pelo solo;

- radiação de onda longa emitida pelo dossel;

- radiação de onda longa emitida pela atmosfera; 
- balanço de onda longa e onda curta no solo;

- balanço de onda longa e onda curta no dossel;

- perdas de vapor d'água pela ventilação;

- perdas de calor latente pela ventilação; 


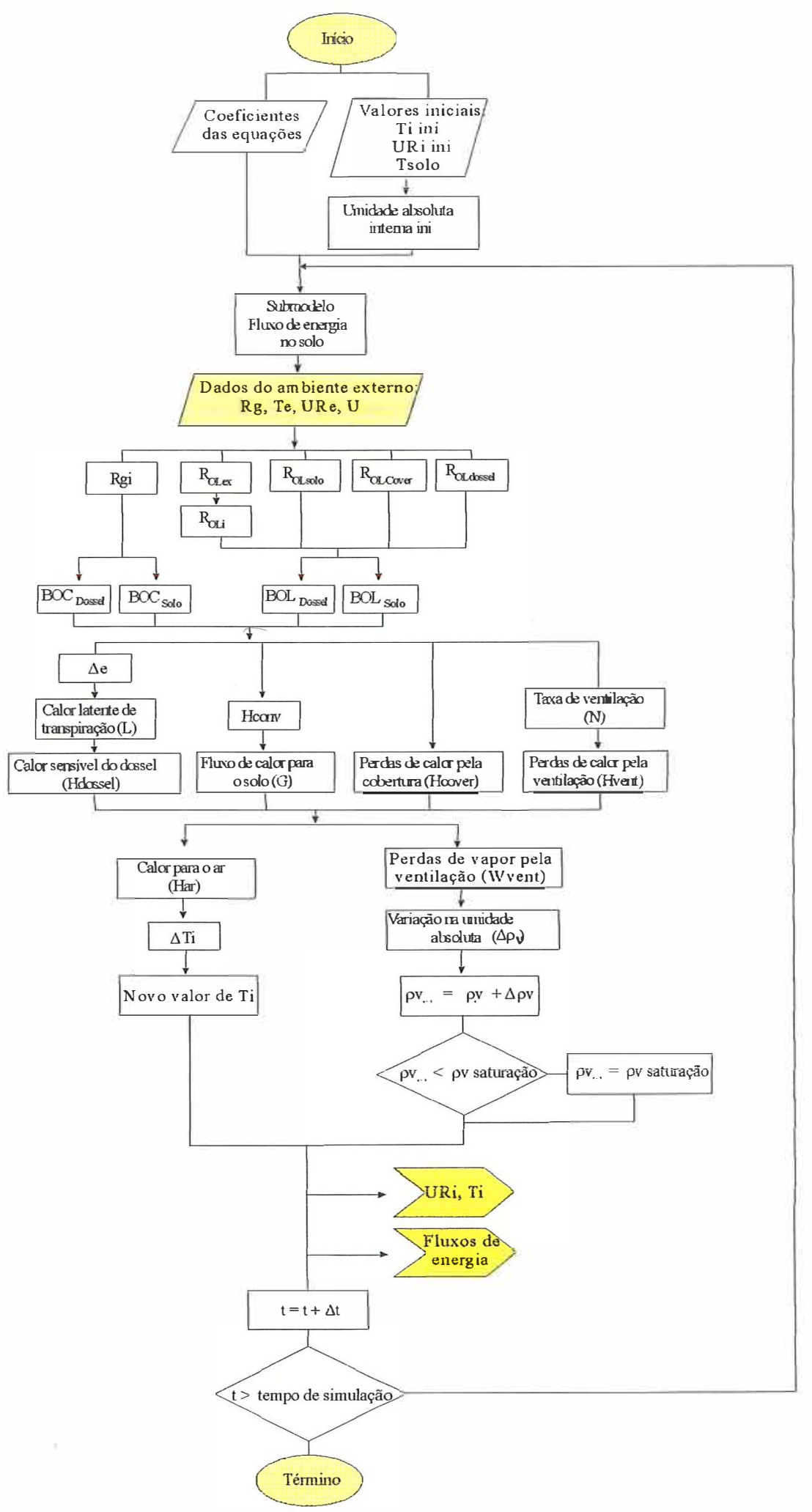

Figura 4. Fluxograma da rotina para resolução do modelo ESTUFA. 


\subsection{COMPORTAMENTO GERAL DO MODELO ESTUFA}

Para verificar o comportamento do modelo ESTUFA, foram simuladas duas condições de abertura de cortinas: uma totalmente fechada ao longo do dia, e outra aberta às 7:00 e fechada às 17:00. A segunda condição representa o manejo normalmente feito pelos produtores em casas-de-vegetação. Essas condições foram testadas em duas épocas do ano, uma de inverno e outra de verão, utilizando dados climáticos externos fornecidos da estação meteorológica automática do departamento de Ciências Exatas, da Escola Superior de Agricultura "Luiz de Queiroz" - USP, localizado na cidade de Piracicaba, SP. Foram utilizados dados meteorológicos dos dias 8 de julho de 1998 e 3 de janeiro de 1999 (Figuras 5, 6 e Tabela 1). Os demais dados e coeficientes encontram-se nas tabelas 2 e 3 .

Foi considerada uma casa-de-vegetação com 40m de comprimento, $7 \mathrm{~m}$ de largura, 2,5m de pé-direito e $1,1 \mathrm{~m}$ de altura do arco. Os coeficientes $a$ e $b$ de transpiração são para a cultura de tomate em estufa extraídos de Joulliet \& Bailey (1992). As transmissividades, de onda curta e onda longa, da cobertura são típicos de uma casa-de-vegetação de polietileno de baixa densidade, material plástico mais usado em casas-de-vegetação no Brasil. 
Tabela 1. Dados meteorológicos externos utilizados para verificar o comportamento do modelo ESTUFA.

\begin{tabular}{|c|c|c|c|}
\hline & \multicolumn{2}{|c|}{ Data } \\
\hline & & $08 / 07 / 98$ & $03 / 01 / 99$ \\
\hline & & Inverno & Verão \\
\hline \multirow{3}{*}{$\begin{array}{l}\text { Temperatura do ar } \\
\qquad\left({ }^{\circ} \mathrm{C}\right)\end{array}$} & Mínima & 12,0 & 20,7 \\
\hline & Média & 19,7 & 24,1 \\
\hline & Máxima & 29,3 & 30,8 \\
\hline \multirow{3}{*}{$\begin{array}{c}\text { Umidade relativa } \\
\text { do ar }(\%)\end{array}$} & Mínima & 30,5 & 63,2 \\
\hline & Média & 70,3 & 92,4 \\
\hline & Máxima & 102,2 & 104,0 \\
\hline \multirow{3}{*}{$\begin{array}{l}\text { Velocidade do } \\
\text { vento }(\mathrm{m} / \mathrm{s})\end{array}$} & Mínima & 0,4 & 0,0 \\
\hline & média & 1,8 & 0,7 \\
\hline & máxima & 4,5 & 4,0 \\
\hline \multicolumn{2}{|c|}{$\begin{array}{l}\text { Radiação solar global total } \\
\left(\mathrm{MJ} / \text { dia. } \mathrm{m}^{2}\right)\end{array}$} & 13,023 & 13,0 \\
\hline
\end{tabular}

Tabela 2. Dados utilizados na resolução do modelo ESTUFA.

\begin{tabular}{|c|c|}
\hline Elemento & Valor \\
\hline Temperatura inicial do solo & $25^{\circ} \mathrm{C}$ \\
\hline Temperatura inicial do ar na casa-de-vegetação & $24^{\circ} \mathrm{C}$ \\
\hline Umidade relativa inicial do ar na casa-de-vegetação & $100 \%$ \\
\hline Passo de tempo para solução numérica das equações & $2 s$ \\
\hline Tempo total de simulação & $24 \mathrm{~h}$ \\
\hline Número de camadas do solo & 1000 \\
\hline Profundidade máxima do solo & $5 \mathrm{~m}$ \\
\hline
\end{tabular}




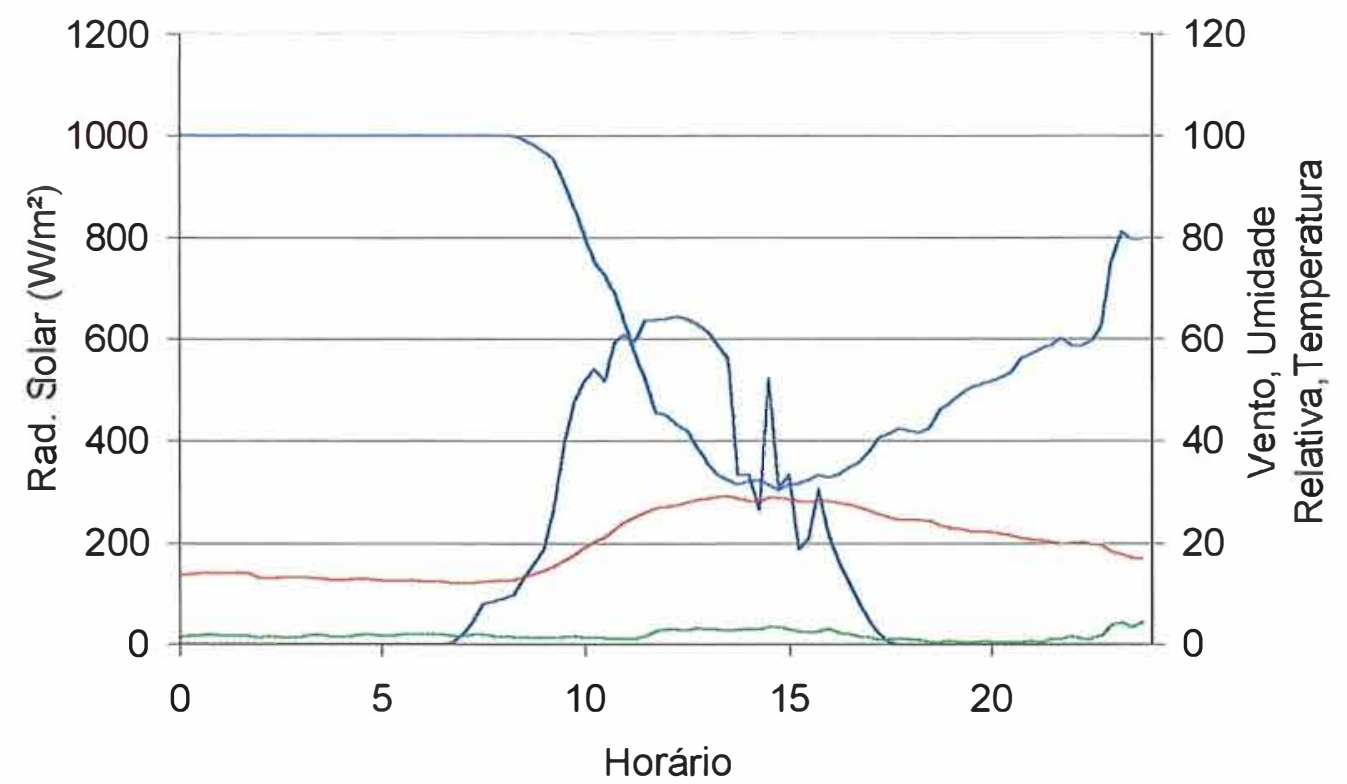

- Radiação solar global $\left(\mathrm{W} / \mathrm{m}^{2}\right)$ - Temperatura do $\operatorname{ar}\left({ }^{\circ} \mathrm{C}\right)$
- Umidade relativa $(\%)$
- Velocidade do vento $(\mathrm{m} / \mathrm{s})$

Figura 5. Dados meteorológicos externos, do dia 08/07/1998, utilizados na simulação pelo modelo ESTUFA.

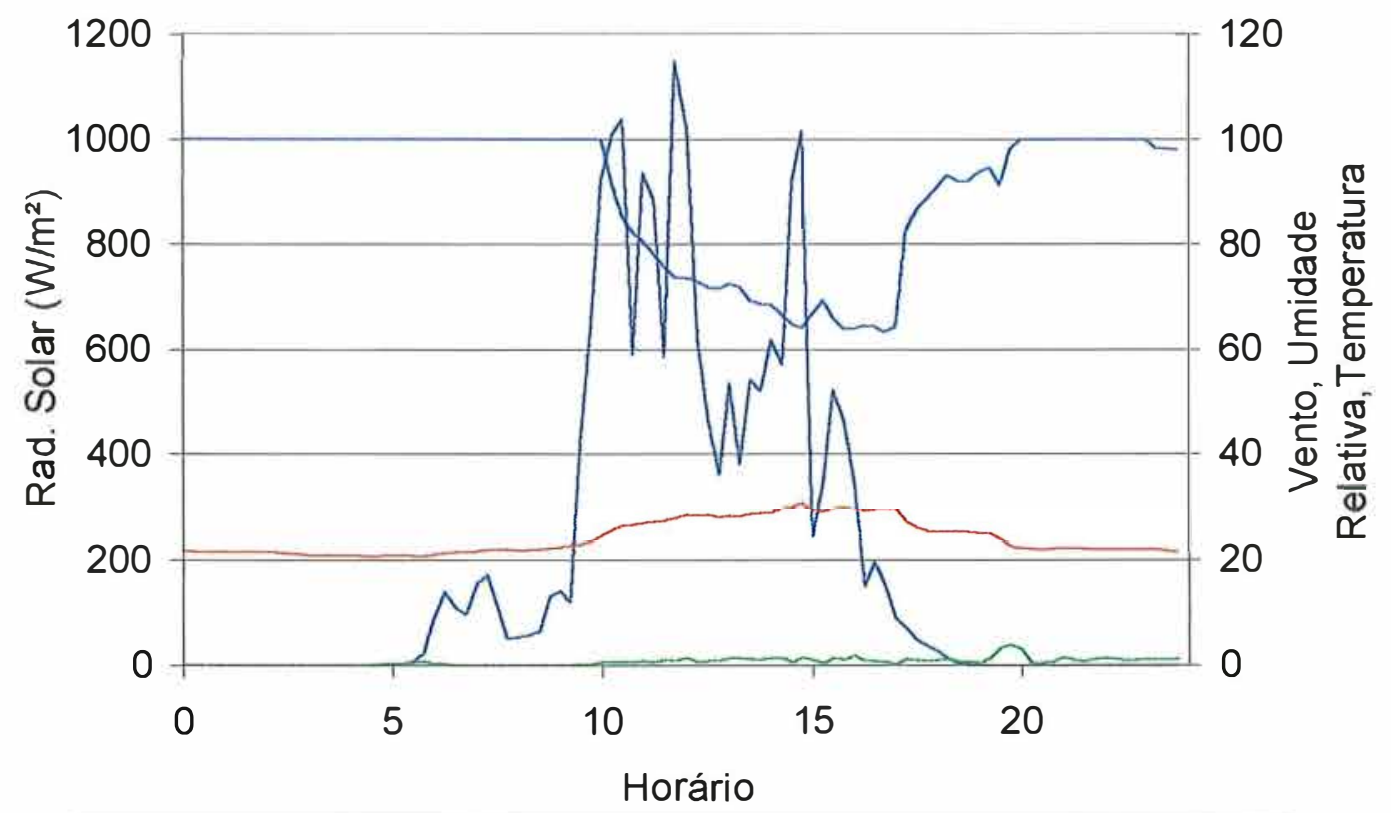
- Radiação solar global (W/m²)
- Temperatura do $\operatorname{ar}\left({ }^{\circ} \mathrm{C}\right)$ Umidade relativa (\%)
— Velocidade do vento $(\mathrm{m} / \mathrm{s})$

Figura 6. Dados meteorológicos externos, do dia 03/01/1999, utilizados na simulação pelo modelo ESTUFA. 
Tabela 1. Coeficientes utilizados na simulação pelo modelo ESTUFA.

\begin{tabular}{|c|c|c|}
\hline Coeficiente & Valor & Referéncia \\
\hline Transmissividade do plástico à radiação de onda curta & 0,7 & Nijskens et al., 1984 \\
\hline Transmissividade do plástico à radiação de onda longa & 0,8 & Nijskens et al., 1984 \\
\hline Refletância do plástico à radiação de onda curta & 0,1 & Nijskens et al., 1984 \\
\hline Refletância do plástico à radiação de onda longa & 0,1 & Nijskens et al., 1984 \\
\hline Coeficiente $A$ para o cálculo do $K c$ & 6,0 & Boulard \& Baille (1993) \\
\hline Coeficiente $B$ para o cálculo do Kc & 0,5 & Boulard \& Baille (1993) \\
\hline Coeficiente $A C w^{0,5}$ para a taxa de ventilação & 0,26 & Boulard et al. (1997) \\
\hline Taxa de ventilação básica $(\mathrm{No})$ & $0,00236 \mathrm{~s}^{-1}$ & Boulard et al. (1997) \\
\hline Refletância do solo à radiação de onda curta & 0,15 & \\
\hline Coeficiente de transferência de calor convectivo & $20 \mathrm{WK}^{-1}$ & Tarara \& Ham, 1999 \\
\hline Condutividade térmica do solo & $0,8 \mathrm{~J} \mathrm{~m}^{-1} \mathrm{~s}^{-1} \mathrm{~K}^{-1}$ & \\
\hline Capacidade térmica do solo & $2.100 .000 \mathrm{~J} \mathrm{~m}^{-3} \mathrm{~K}^{-1}$ & \\
\hline Emissividade do solo & 0,8 & \\
\hline Capacidade térmica do ar & $1139,18 \mathrm{~J} \cdot \mathrm{m}^{-3} \cdot \mathrm{K}^{-1}$ & Ometto, 1981 \\
\hline Emissividade do ar externo & 0,8 & \\
\hline Coeficiente $a$ para calor latente de transpiração, para cultura de tomate & 0,34545 & Joulliet \& Bailey, 1992 \\
\hline Coeficiente $b$ para calor latente de transpiração, para cultura de tomate & 68,845 & Joulliet \& Bailey, 1992 \\
\hline Indice de área Foliar $(I A F)$ & 3 & \\
\hline Refletância da folha à radiação de onda curta & 0,30 & Jones, 1992 \\
\hline Transmissividade das folhas à radiação de onda curta & 0,30 & Jones, 1992 \\
\hline Coeficiente de extinção do dossel $(K)$ & 0,67 & \\
\hline Emissividade do dossel & 0,98 & Takakura et al., 1971 \\
\hline
\end{tabular}




\subsection{ANÁLISE DE SENSIBILIDADE}

A influência de alguns dos dados de entrada do modelo sobre a temperatura e umidade relativa do ar no interior da estufa foi verificada por análise de sensibilidade. Foram simuladas três situações, uma comumente encontrada em literatura (valor de referência) e outras com valores acima e abaixo da situação típica, representando uma faixa normal de variação dos elementos testados, cujos valores são apresentados na Tabela 4, sendo os valores de referência e os coeficientes dados nas Tabelas 2 e 3 . Estes elementos são os que, em geral, apresentam maiores variações em medições de campo ou mostram certa dificuldade na determinação. O percentual de abertura das cortinas foi mantido constante ao longo de todo dia simulado.

Testou-se também o efeito da radiação solar global externa, temperatura e umidade relativa do ar, e velocidade do vento, sobre as saídas do modelo. Foram usados valores $20 \%$ abaixo e acima dos valores de referência. Foram empregados dados externos do dia 14 de abril de 1998, coletados na estação meteorológica do departamento de Ciências Exatas-ESALQ-USP, Piracicaba, $\mathrm{SP}$, representados na Figura 7.

Cada simulação gerou uma tabela com a evolução da temperatura e umidade relativa do ar, ao longo do dia, em que foram determinados os valores mínimo, médio e máximo. 
Tabela 4. Dados de entrada do modelo ESTUFA utilizados na análise de sensibilidade.

\begin{tabular}{|c|c|c|c|}
\hline Elemento analisado & Inferior & $\begin{array}{l}\text { Valor de } \\
\text { referência }\end{array}$ & Superior \\
\hline Altura do pé direito $(\mathrm{m})$ & 1,5 & 2,5 & 4 \\
\hline Comprimento da casa-de-vegetação (m) & 20 & 40 & 60 \\
\hline Largura da casa-de-vegetação $(\mathrm{m})$ & 4 & 7 & 10 \\
\hline Altura do arco $(\mathrm{m})$ & 0,70 & 1,1 & 1,5 \\
\hline Transmissividade de onda curta & 0,5 & 0,7 & 0,9 \\
\hline Transmissividade de onda longa & 0,1 & 0,8 & 0,9 \\
\hline Coeficiente $A$ para o cálculo do $K c$ & 4 & 6,0 & 8 \\
\hline $\begin{array}{l}\text { Coeficiente } A C w^{0,5} \text { para a taxa de } \\
\text { ventilação }\end{array}$ & 0,1 & 0,26 & 0,5 \\
\hline $\begin{array}{l}\text { Coeficiente de transferência de calor } \\
\text { convectivo, } h s\left(\mathrm{~W} \mathrm{~K}^{-1}\right)\end{array}$ & 4 & 20 & 30 \\
\hline $\begin{array}{l}\text { Coeficiente a para calor latente de } \\
\text { transpiração, para cultura de tomate }\end{array}$ & $\begin{array}{l}0,27636 \\
(-20 \%)\end{array}$ & 0,34545 & $\begin{array}{l}0,4145 \\
(+20 \%)\end{array}$ \\
\hline $\begin{array}{l}\text { Coeficiente } b \text { para calor latente de } \\
\text { transpiração, para cultura de tomate }\end{array}$ & $\begin{array}{l}55,076 \\
(-20 \%)\end{array}$ & 68,845 & $\begin{array}{l}82,614 \\
(+20 \%)\end{array}$ \\
\hline Coeficiente de extinção do dossel $(K)$ & 0,4 & 0,67 & 1,0 \\
\hline Percentual de abertura de cortinas & 0 & 0,5 & 1 \\
\hline Radiação solar global externa & $-20 \%$ & 0 & $+20 \%$ \\
\hline Temperatura do ar externa & $-20 \%$ & 0 & $+20 \%$ \\
\hline Umidade relativa do ar externa & $-20 \%$ & 0 & $+20 \%$ \\
\hline Velocidade do vento externa & $-20 \%$ & 0 & $+20 \%$ \\
\hline
\end{tabular}




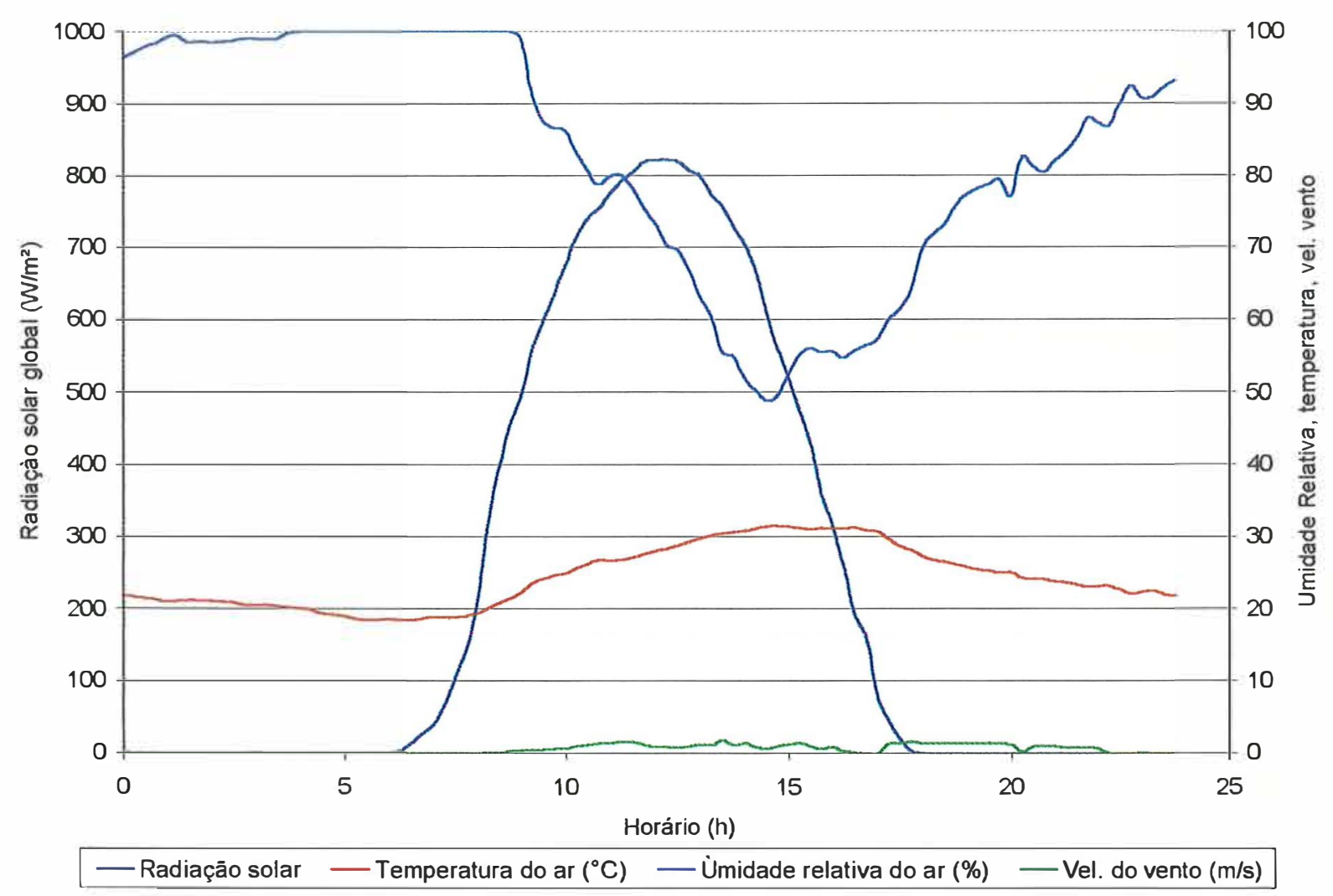

Figura 7. Dados meteorológicos externos utilizados na análise de sensibilidade, do dia 14 de abril de 1998.

Tabela 5. Condições meteorológicas externas utilizadas na análise de sensibilidade, do dia 14 de abril de 1998.

\begin{tabular}{crr}
\hline \multirow{2}{*}{ Temperatura do ar $\left({ }^{\circ} \mathrm{C}\right)$} & Mínima & 18,5 \\
& Média & 24,4 \\
& Máxima & 31,6 \\
\hline \multirow{2}{*}{ Umidade relativa do ar } & Mínima & 49,0 \\
$(\%)$ & Média & 83,1 \\
& Máxima & 100,0 \\
\hline Velocidade do vento & Mínima & 0,0 \\
$(\mathrm{~m} / \mathrm{s})$ & Média & 0,6 \\
Radiação solar global $\left(\mathrm{MJ} /\right.$ dia. $\left.^{2}{ }^{2}\right)$ & & 1,9 \\
\hline & & 19,70 \\
\hline
\end{tabular}




\subsection{COMPARAÇÃO COM DADOS DE CAMPO}

O modelo ESTUFA foi comparado com dados coletados em uma casade-vegetação, sem cultura, com os gerados com o modelo. $O$ efeito da ausência de cultura pôde ser simulado fazendo-se IAF $=0$ e os coeficientes de transpiração, $a$ e $b$, (eq. (14)) iguais a zero. Como o solo se mostrava seco, a sua evaporação também pôde ser negligenciada.

A ausência de cultura não possibilitou uma avaliação completa do modelo. Nessa condição não ocorreram interações da radiação com o dossel, nem o processo de transpiração, mas os resultados permitiram verificar o comportamento geral do balanço de energia no solo, na cobertura e no ar da casa-de-vegetação.

A casa-de-vegetação testada possuía as dimensões de $17,5 \times 6,4 \mathrm{~m}$, pé direito de $3 \mathrm{~m}$, altura do arco de $1,1 \mathrm{~m}$, coberta com filme de PVC. Foram coletadas temperatura e umidade relativa do ar, radiação solar, fluxo de calor no solo e radiação líquida, através de uma estação meteorológica automática, com médias em intervalos de 30 minutos, dos dias 10 e 23 de novembro de 1999, com a casa-de-vegetação fechada e aberta, respectivamente. Os sensores se encontravam a $2,0 \mathrm{~m}$ do solo e a um metro da lateral da casa-devegetação. Os dados externos foram fornecidos da estação meteorológica automática, do departamento de Ciências Exatas, ESALQ-USP.

Os outros dados e coeficientes foram os mesmos das tabelas 2 e 3 , diferindo apenas nas características radiométricas da cobertura, nos coeficientes de transpiração e na condutividade e capacidade térmicas do solo, onde foram usados valores típicos de uma solo seco. Estes são apresentados na Tabela 6. 
Tabela 6. Coeficientes utilizados no teste do modelo ESTUFA com dados de campo.

\begin{tabular}{|l|l|}
\hline Transmissividade de onda curta (PVC) & 0,5 \\
\hline Transmissividade de onda longa (PVC) & 10,01 \\
\hline Refletividade de onda curta (PVC) & 0,08 \\
\hline Refletividade de onda longa (PVC) & 0,05 \\
\hline Condutividade térmica do solo & $0,18 \mathrm{~J} \mathrm{~m}^{-1} \mathrm{~s}^{-1} \mathrm{~K}^{-1}$ \\
\hline Capacidade térmica do solo & $0,9 \mathrm{MJ} \mathrm{m}^{-3} \mathrm{~K}^{-1}$ \\
\hline $\begin{array}{l}\text { Coeficiente } a \text { para calor latente de transpiração, } \\
\text { para cultura de tomate }\end{array}$ & 0 \\
\hline $\begin{array}{l}\text { Coeficiente } b \text { para calor latente de transpiração, } \\
\text { para cultura de tomate }\end{array}$ & 0 \\
\hline Indice de área foliar (IAF) & 0 \\
\hline
\end{tabular}

A baixa transmissividade da cobertura, calculado com medições anteriores, foi devido ao grande acúmulo de poeira. A transmissividade em um filme novo de PVC geralmente assume valores em torno de 0,9.

O fluxo de calor para o solo simulado foi obtido diretamente da saída do programa. Como não havia uma cobertura vegetal, a radiação líquida simulada pode ser calculada pela soma dos balanços de onda curta e onda longa na superfície do solo.

Foram usadas apenas as saídas do modelo a cada 30 minutos, para compatibilidade com os dados medidos na casa-de-vegetação. em que se ajustaram retas, através de regressão linear, entre os dados medidos e os dados simulados, tendo a origem o cruzamento dos dois eixos. 


\section{RESULTADOS E DISCUSSÃO}

\subsection{COMPORTAMENTO DO MODELO ESTUFA}

$\mathrm{Na}$ Tabela 7 são apresentados os principais resultados das 4 condições simuladas para temperatura e umidade relativa do ar, dentro e fora da casa-devegetação, e a diferença entre os valores de temperatura do ar interna e externa a casa-de-vegetação.

Tabela 7. Temperatura e umidade relativa do ar e diferença entre temperatura do ar interna e externa, simuladas durante o verão e inverno e sob estufa com cortinas aberta e fechadas.

\begin{tabular}{|c|c|c|c|c|c|c|}
\hline \multirow{2}{*}{$\begin{array}{c}\text { Época do anc } \\
\text { Condição }\end{array}$} & & \multicolumn{2}{|c|}{$\begin{array}{c}\text { Temperatura do ar } \\
\left({ }^{\circ} \mathrm{C}\right)\end{array}$} & \multicolumn{2}{|c|}{$\begin{array}{c}\text { Umidade Relativa do } \\
\operatorname{ar}(\%)\end{array}$} & \multirow{2}{*}{\begin{tabular}{|c} 
Diferença entre \\
temperatura \\
interna e \\
externa $\left({ }^{\circ} \mathrm{C}\right)$
\end{tabular}} \\
\hline & & Externa & Interna & Externa & Interna & \\
\hline \multirow{3}{*}{$\begin{array}{l}\text { Verão } \\
\text { aberto }\end{array}$} & Máxima & 30,8 & 31,9 & 100,0 & 100,0 & 5,3 \\
\hline & Média & 24,1 & 25,6 & 90,6 & 87,4 & 1,5 \\
\hline & Mínima & 20,7 & 22,2 & 63,2 & 63,8 & $-0,2$ \\
\hline \multirow{3}{*}{$\begin{array}{l}\text { Verão } \\
\text { fechado }\end{array}$} & Máxima & 30,8 & 37,4 & 100,0 & 100,0 & 8,4 \\
\hline & Médi & 24, & 26 & 90 & 91 & 2,7 \\
\hline & Mínima & 20,7 & 22 & 63,2 & 78 & 0,5 \\
\hline \multirow{3}{*}{$\begin{array}{c}\text { Inverno } \\
\text { aberto }\end{array}$} & Máxima & 29,3 & 29,2 & 100,0 & 100,0 & 4,4 \\
\hline & & & 20 & 70 & 71 & 1 \\
\hline & & 12 & 12,6 & 30,5 & 32,1 & $-1,1$ \\
\hline \multirow{3}{*}{$\begin{array}{l}\text { Inverno } \\
\text { fechado }\end{array}$} & Máxima & 29,3 & 31,1 & 100,0 & 100,0 & 4,6 \\
\hline & Médi & 19 & 21,6 & 70,5 & 79,6 & 2,0 \\
\hline & Mínima & 12,0 & 14,8 & 30,5 & 61,7 & $-0,8$ \\
\hline
\end{tabular}

A simulação em um dia de verão e em casa-de-vegetação com as cortinas abertas não mostrou grandes variações entre o ambiente interno e externo, observando diferença média de $1,5^{\circ} \mathrm{C}$ para temperatura do ar e $3,2 \%$ para umidade relativa do ar. Comportamento semelhante foi descrito por 
Martins et al. (1994), em um estudo com a cultura do tomate em casa-devegetação com laterais abertas, em que encontraram diferenças variando de 1 a $2^{\circ} \mathrm{C}$ nas temperaturas do ar interna e externa, e diferenças de 1 a $2 \%$ entre as umidades relativas do ar interna e externa. Isso é explicada pelo aumento nas trocas de calor e de vapor d'água pela ventilação, entre os ambientes interno e externo a casa-de-vegetação, promovida pela abertura das cortinas. Martins et al. (1994) também mencionaram a boa ventilação como causa da proximidade da temperatura e umidade relativa do ar interna e externa.

O efeito da ventilação também pode ser visualizado na condição de casa-de-vegetação com cortinas fechadas, onde houve um aumento das diferenças médias entre as temperaturas do ar, interna e externa, em $2,7^{\circ} \mathrm{C}$ e $2,0^{\circ} \mathrm{C}$. respectivamente para dia de verão e de inverno. A maior influência do fechamento ocorreu sobre a temperatura do ar máxima, com diferenças de $6,6^{\circ} \mathrm{C}$ e $1,8^{\circ} \mathrm{C}$, respectivamente para dia de verão e de inverno.

As temperaturas mínimas do ar no interior da casa-de-vegetação se mostraram sempre superiores em relação ao exterior. As diferenças no verão foram de $1,5^{\circ} \mathrm{C}$, tanto para casa-de-vegetação com cortinas abertas como fechadas, e no inverno de $0,5^{\circ} \mathrm{C}$ e $2,8^{\circ} \mathrm{C}$, respectivamente para casa-devegetação com cortinas abertas e fechadas. Valores semelhantes foram encontrados por e Farias et al. (1993b) trabalhando em casa-de-vegetação tipo capela, com diferenças entre as temperaturas mínimas do ar interna e externa a casa-de-vegetação variando de 0 a $4,6^{\circ} \mathrm{C}$. Buriol et al. (1993) mesmo encontrando diferenças médias positivas entre as temperaturas mínimas do ar no interior e exterior da casa-de-vegetação, verificaram vários dias com diferenças negativas, o que não foi observado no presente trabalho. Isso indica a necessidade de maiores testes com o modelo para avaliação do comportamento sob variadas condições.

Os resultados com casas-de-vegetação com cortinas abertas mostraram uma tendência de aumento nas diferenças entre as temperaturas do ar, interna 
e externa, do inverno para o verão, o que pode ser explicado pelo balanço de radiação mais positivo na casa-de-vegetação, devidos aos maiores valores de radiação solar global no verão. Farias et al. (1993b) também encontraram comportamento similar. Os mesmos autores encontraram diferenças pequenas entre umidade relativa do ar, interna e externamente a casa-de-vegetação, também observados no presente trabalho.

O fechamento das cortinas da casa-de-vegetação influenciou a umidade relativa do ar mínima (Tabela 7 ), demonstrando o efeito da redução da ventilação na diminuição das trocas de vapor d'água. Com as cortinas fechadas, pode-se observar um aumento na umidade relativa do ar em $14,3 \%$, em dia de verão, e 29,6\%, em dia de inverno. Tal comportamento é apresentado nas Figuras 8, 9, 10 e 11, em que as curvas de umidade relativa do ar, no interior e exterior da casa-de-vegetação, se encontram próxima durante o dia na condição de cortinas abertas. Com o fechamento das cortinas a mesma curva tende a sofrer uma queda menos acentuada, comparada com a umidade relativa externa.

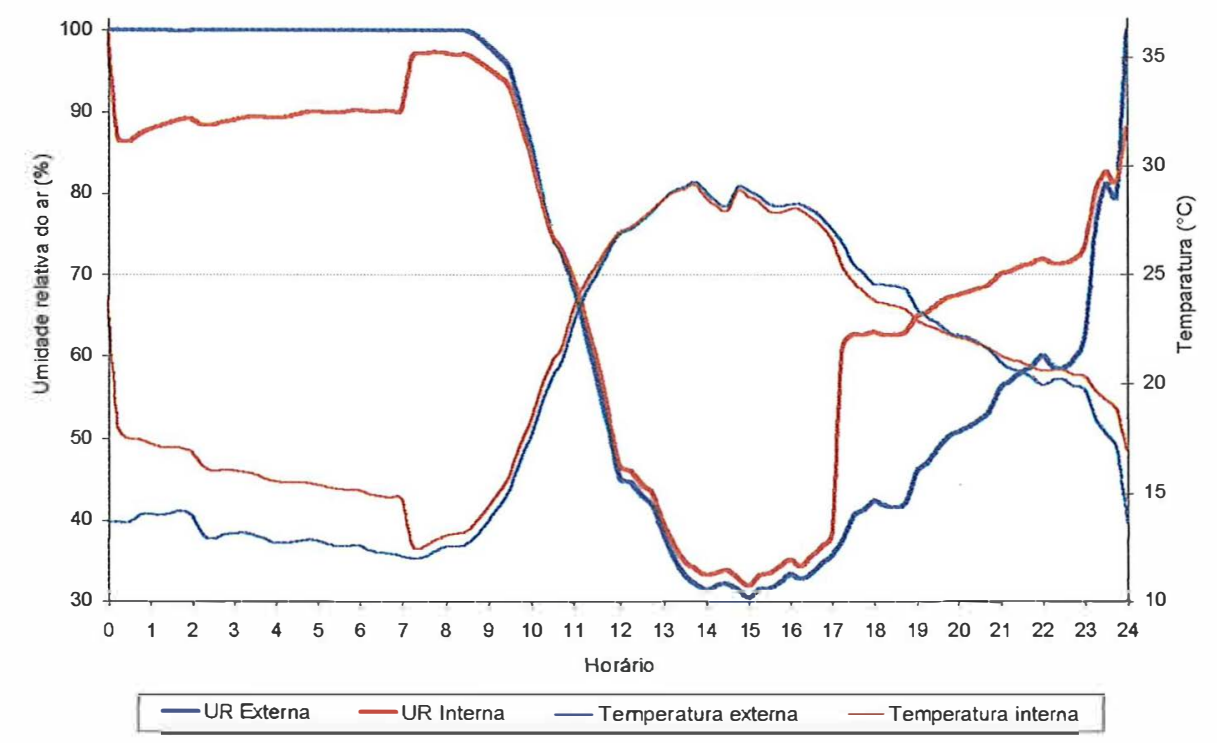

Figura 8. Variação da temperatura e umidade relativa do ar, interna e externamente, em dia de inverno e com casa-de-vegetação com cortinas abertas. 


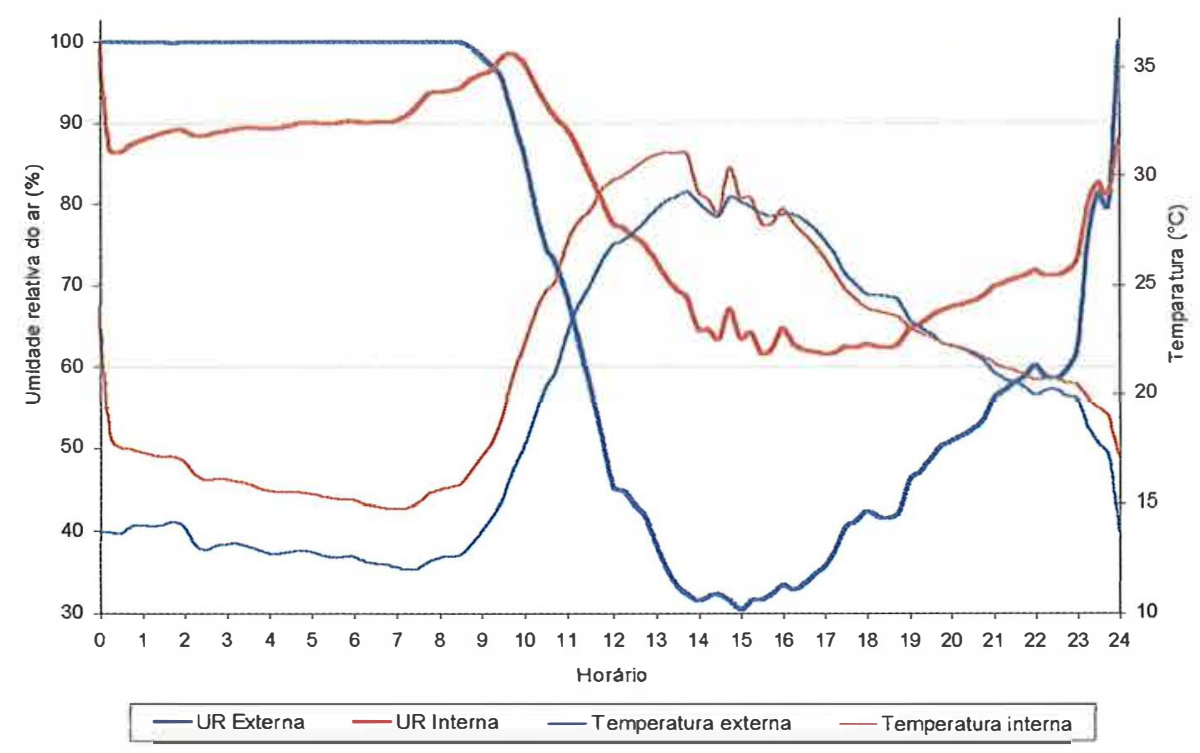

Figura 9. Variação da temperatura e umidade relativa do ar, interna e externamente, em dia de inverno e com casa-de-vegetação com cortinas fechadas.

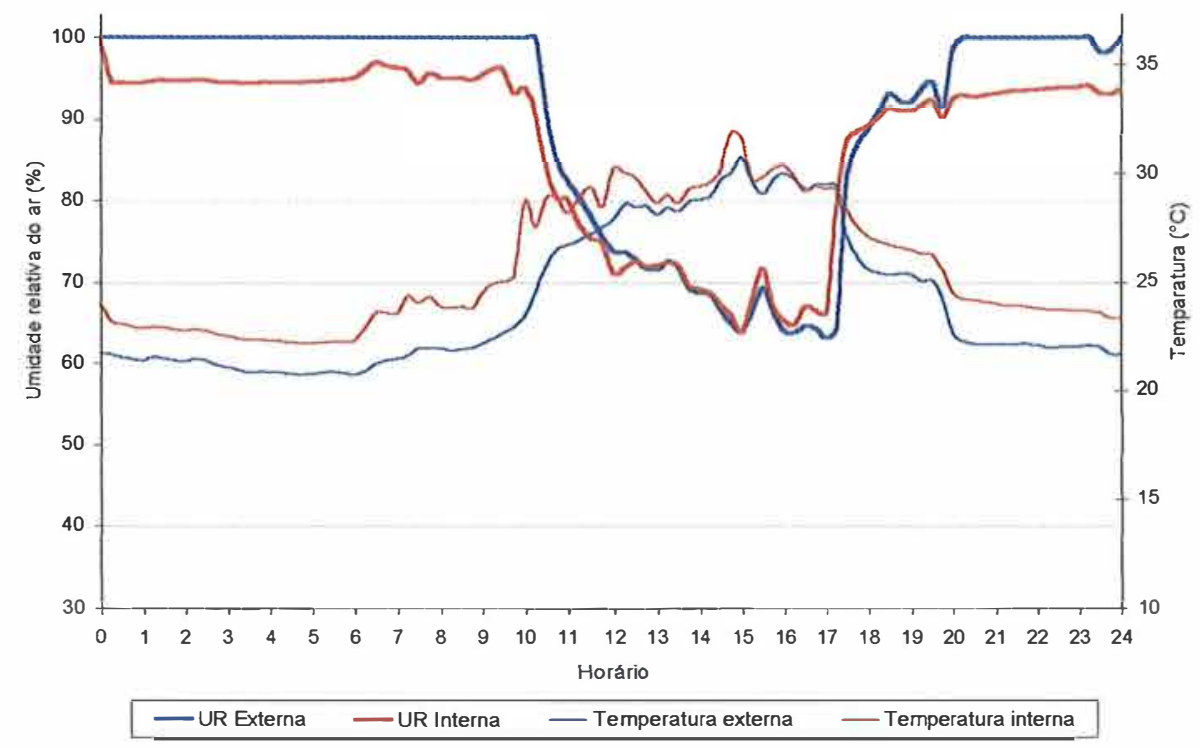

Figura 10. Variação da temperatura e umidade relativa do ar, interna e externamente, em dia de verão e com casa-de-vegetação com cortinas abertas. 


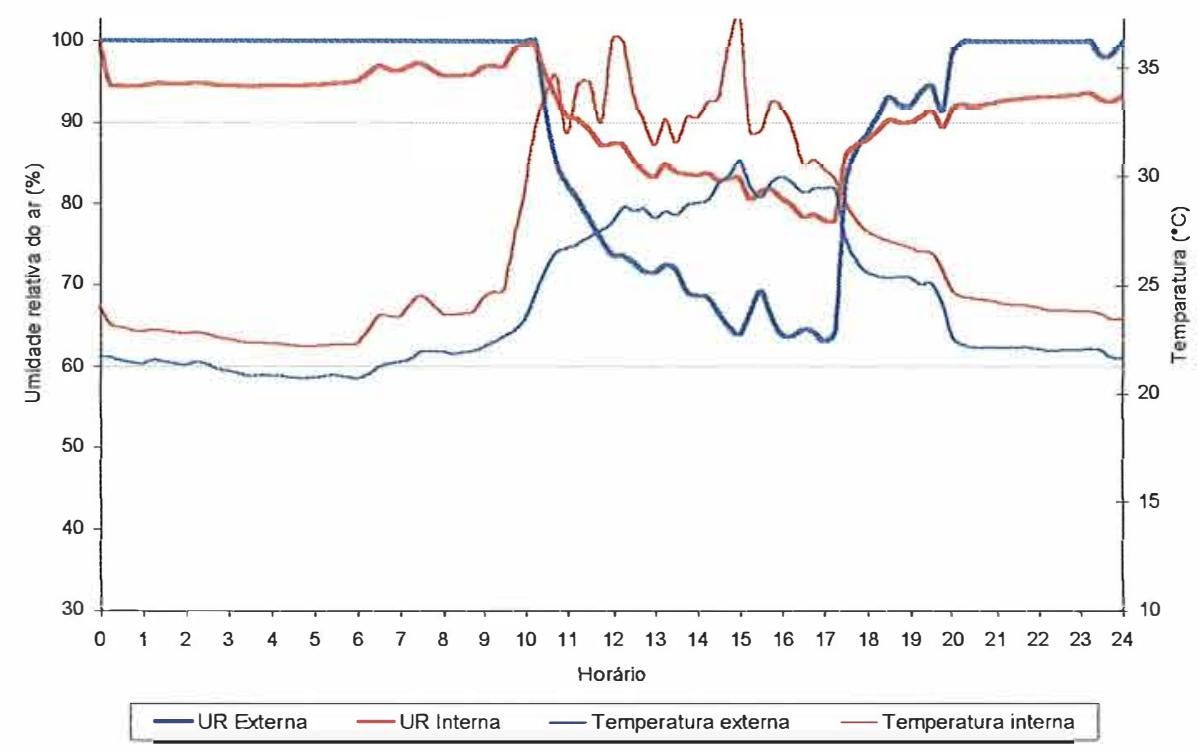

Figura 11. Variação da temperatura e umidade relativa do ar, interna e externamente, em dia de verão e com casa-de-vegetação com cortina fechadas.

$\mathrm{Na}$ Figura 12 estão plotados os valores simulados das densidades de fluxos de energia diário que compõem o balanço de energia no ar da casa-devegetação. Verifica-se que os principais fluxos foram: calor convectivo do solo; perdas através da ventilação; e perdas através da cobertura plástica. Isso demonstra que um dos principais meios de entrada de calor é o solo, através do calor sensível convectivo gerado pelo saldo de radiação. No verão, os fluxos mais afetados com o fechamento das cortinas da casa-de-vegetação foram as perdas de calor sensivel pela ventilação e as perdas através da cobertura, com a diminuição do primeiro e aumento do último, este devido ao aumento da área das cortinas. Mesmo com variações próximas entre casa-de-vegetação com cortinas abertas e fechadas, a redução nas perdas calor pela ventilação ($1508 \mathrm{~kJ} \cdot \mathrm{dia}^{-1} \cdot \mathrm{m}^{-2}$ ) foram maiores que o aumento nas perdas pela cobertura $\left(+1507 \mathrm{~kJ} \cdot \mathrm{dia}^{-1} \cdot \mathrm{m}^{-2}\right)$, promovendo temperaturas médias maiores na casa-devegetação com cortinas fechadas. 


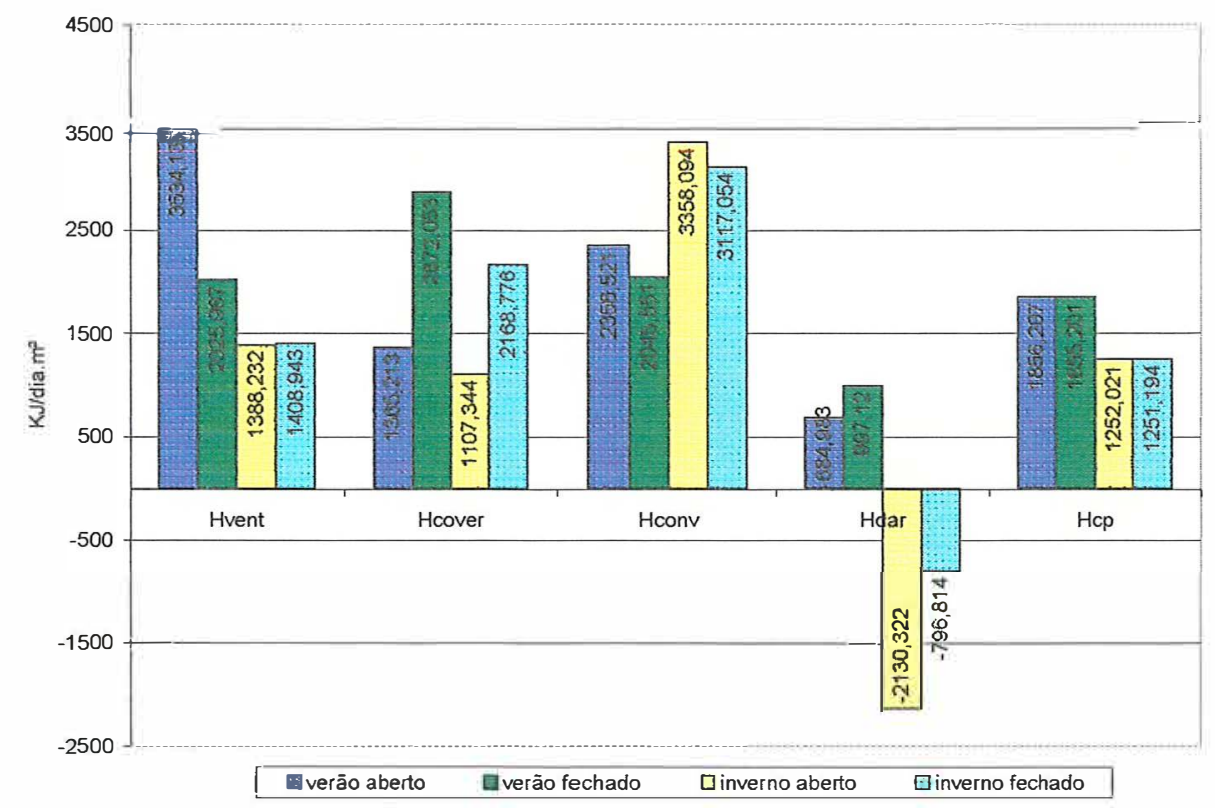

Figura 12. Densidade de fluxo diário dos componentes do balanço de energia no ar da estufa simulados para verão e inverno e sob casa-devegetação com cortinas abertas e fechadas. Hvent = perdas de calor através da ventilação; Hcover = perdas de calor através da cobertura; Hconv = calor convectivo do solo para o ar; Hdar = calor convectivo do dossel para o ar; $\mathrm{Hcp}=$ calor convectivo da cobertura para o ar na casa-de-vegetação; todos em $\mathrm{kJ} \mathrm{dia}^{-1} \mathrm{~m}^{-2}$.

No inverno, o fechamento das cortinas da casa-de-vegetação praticamente não gerou variação nas perdas de energia pela ventilação, mas manteve o aumento nas perdas pela cobertura plástica. Ainda, observa-se pela Figura 12 uma inversão no fluxo de calor convectivo do dossel para o ar da casa-de-vegetação, explicada pela menor disponibilidade de energia desta época do ano. Isso afeta principalmente o balanço de radiação no dossel (Figura 13), fazendo com que o dossel comporte-se como um dreno de calor. $O$ fechamento das cortinas da casa-de-vegetação provocou um aumento na densidade de fluxo de energia do dossel para o ar (Figura 12), amenizando a retirada de calor pelo dossel. 


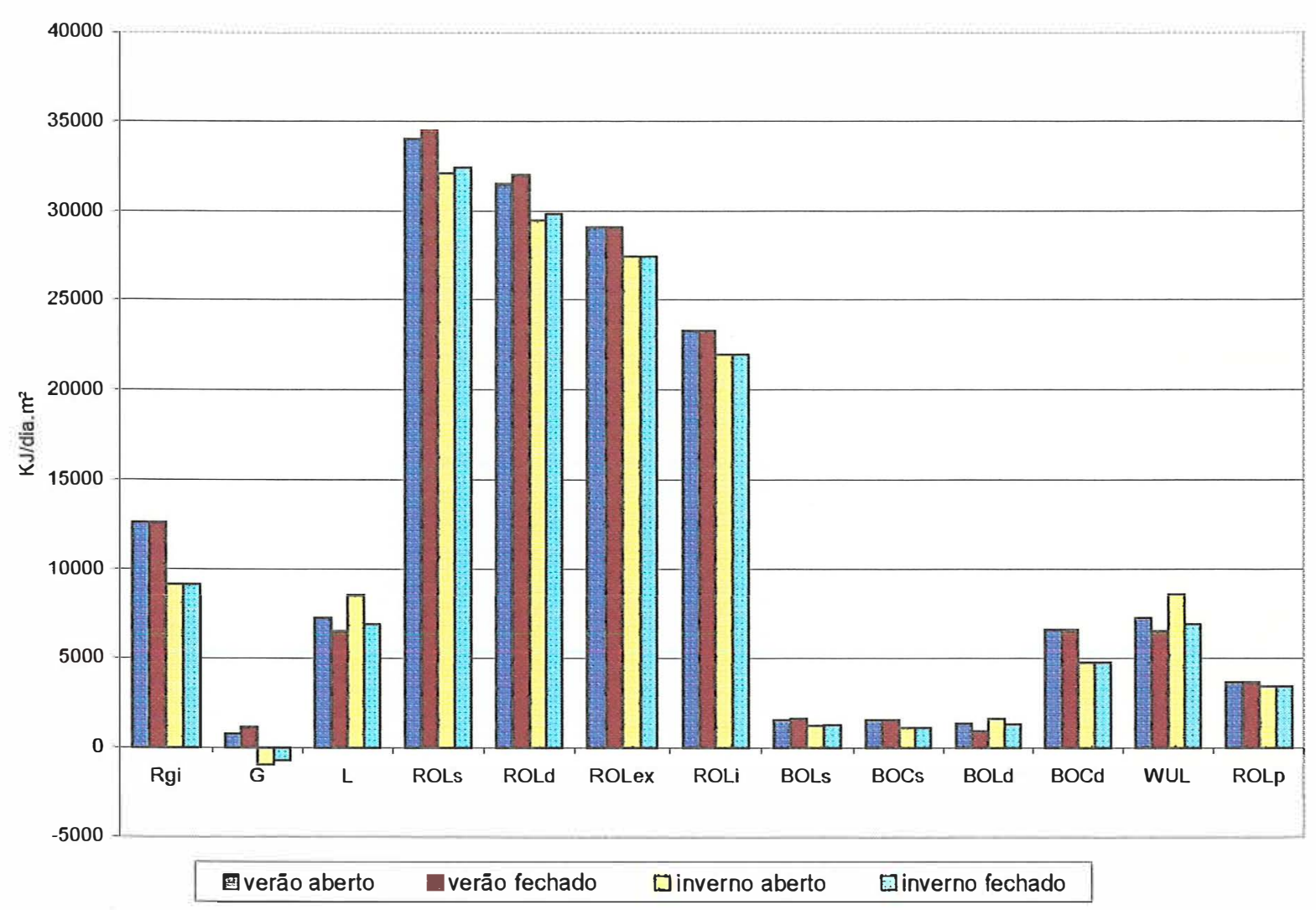

Figura 13 Densidade de fluxos de energia diário gerados pelo modelo. Rgi = Radiação global interna; $\mathrm{G}$ = fluxo de calor no solo; $R O L s=$ radiação emitida pelo solo; $\mathrm{ROLd}=$ radiação emitida pelo dossel; $\mathrm{ROLi}=$ radiação de onda longa proveniente da cobertura; $R O L e x=$ radiação emitida pela atmosfera; BOLs = balanço de onda longa no solo; BOCs = balanço de onda curta no solo; $\mathrm{BOLd}=$ balanço de onda longa no dossel; $\mathrm{BOCd}=$ balanço de onda curta no dossel; $\mathrm{WUL}=$ perda de calor latente pela ventilação; ROLp = radiação emitida pelo plástico; todos em $\mathrm{kJ} \mathrm{dia}^{-1} \mathrm{~m}^{-2}$.

Pode-se notar ainda pela Figura 12 que, mesmo com a casa-devegetação com as cortinas fechadas, as perdas de calor pela ventilação representam uma grande proporção do total, indicando que uma vedação mais eficiente da estrutura possibilita uma conservação maior de calor, principalmente em noites mais frias de inverno.

Na Figura 13 são apresentados os resultados simulados de densidade de fluxo de energia para os demais componentes do balanço de energia. 
Destacam-se os fluxos de radiação emitidos pelo solo, dossel e atmosfera e a radiação de onda longa proveniente da cobertura, que variaram de $34.038 \mathrm{~kJ} \cdot \mathrm{dia}^{-1} \cdot \mathrm{m}^{-2}$ a $21.972 \mathrm{~kJ} \cdot \mathrm{dia}^{-1} \cdot \mathrm{m}^{-2}$, e se mostraram comparativamente superiores aos demais, que variaram de $-360 \mathrm{~kJ} \cdot \mathrm{dia}^{-1} \cdot \mathrm{m}^{-2}$ a $1.2610 \mathrm{~kJ} \cdot \mathrm{dia}^{-1} \cdot \mathrm{m}^{-2}$. Isso demonstra que em manejos objetivando a dissipação ou a conservação de energia em casas-de-vegetação, o balanço de onda longa é um dos principais componentes a serem levados em conta.

As Figuras 8, 9, 10 e 11 apresentam a variação da temperatura e umidade relativa do ar, interna e externa à casa-de-vegetação, para as condições simuladas. Observa-se que a temperatura e a umidade relativa do ar rapidamente entram em equilíbrio após o inicio da simulação, demonstrando que os valores iniciais de temperatura e umidade relativa do ar e temperatura do solo internas não afetam pronunciadamente os resultados simulados pelo modelo. Já no primeiro 15 minutos não se nota o efeito dos valores iniciais sobre a temperatura e umidade relativa interna. As maiores diferenças de temperatura entre o ambiente interno e externo (Figuras 8, 9, 10 e 11), no início da simulação até a metade do dia, possivelmente foram provocados pelas menores perdas através da ventilação durante a noite (casa-de-vegetação fechada) e pela liberação da energia acumulada no solo.

\subsection{ANÁlise de SENSIBILIDADE}

Os valores absolutos gerados pela simulação encontram-se em Anexo. Pela Tabela 8 verifica-se que os elementos que geraram as maiores amplitudes de temperatura média do ar simulada, entre os limites inferior e superior, foram: temperatura do ar externa, coeficiente de extinção $(K)$ e o percentual de abertura das cortinas $(P a b)$. Nijskens et al. (1991) também encontraram que a temperatura do ar externa foi o parâmetro de maior influência sobre a temperatura do ar na casa-de-vegetação, seguido da radiação solar externa. Os 
mesmos autores ainda indicam que, dentre os coeficientes do modelo, aqueles ligados à radiação de onda longa na cobertura da casa-de-vegetação (transmissividade e emissividade) se mostraram importantes no balanço de energia, o que também foi verificado no presente trabalho. $A$ transmissividade de onda longa $\left(\tau_{\mathrm{OL}}\right)$ aparece entre os elementos analisados que mais afetam a temperatura do ar, principalmente sobre a temperatura mínima do dia (Tabela 8).

Tabela 8. Amplitude de variação da temperatura e umidade relativa do ar simulada entre os limites inferior e superior de cada elemento testado.

\begin{tabular}{|c|c|c|c|c|c|c|}
\hline Elemento analisado & \multicolumn{3}{|c|}{ Temperatura $\left({ }^{\circ} \mathbf{C}\right)$} & \multicolumn{4}{c|}{ UR (\%) } \\
& mínima & média máxima & mínima média máxima \\
\hline Altura do pé direito & $-0,6$ & $-0,6$ & $-0,6$ & $-3,3$ & $-0,7$ & 0,0 \\
\hline $\begin{array}{c}\text { Comp. da casa-de- } \\
\text { vegetação }\end{array}$ & 0,1 & 0,0 & 0,0 & 0,0 & $-0,1$ & 0,0 \\
\hline $\begin{array}{c}\text { Largura da casa-de- } \\
\text { vegetação }\end{array}$ & 0,1 & 0,3 & 0,4 & 2,6 & 0,2 & 0,0 \\
\hline Altura do arco & $-0,2$ & $-0,1$ & 0,0 & 0,0 & 0,0 & 0,0 \\
\hline Transm. de OC & 0,0 & $-0,3$ & $-0,8$ & 2,5 & 1,8 & 0,0 \\
\hline Transm. de OL & $-1,3$ & $-0,7$ & $-0,5$ & 0,8 & 2,5 & 0,0 \\
\hline Coef. A para Kc & $-0,4$ & $-0,2$ & 0,0 & 0,0 & 0,6 & 0,0 \\
\hline ACwO,5 & 0,0 & $-0,5$ & $-0,9$ & $-5,2$ & $-1,0$ & 0,0 \\
\hline hs & 0,6 & 0,2 & 0,0 & $-0,1$ & $-0,9$ & 0,0 \\
\hline Coef. a para L & 0,0 & $-0,2$ & $-0,6$ & 1,9 & 1,3 & 0,0 \\
\hline Coef. b para L & $-0,1$ & $-0,2$ & $-0,6$ & 2,0 & 1,4 & 0,0 \\
\hline Coef. de extinção(K) & $-4,4$ & $-2,8$ & $-2,5$ & 5,1 & 9,8 & 0,0 \\
\hline Pab & 0,3 & $-1,3$ & $-3,5$ & $-22,2$ & $-6,5$ & 0,0 \\
\hline Rg & 0,0 & 0,3 & 0,9 & $-0,8$ & $-0,5$ & 0,0 \\
\hline Te & 6,3 & 8,6 & 10,9 & 2,0 & 3,2 & 0,0 \\
\hline URe & 0,6 & 0,6 & 0,7 & 17,4 & 17,2 & 0,0 \\
\hline U & 0,0 & $-0,1$ & $-0,2$ & $-1,3$ & $-0,2$ & 0,0 \\
\hline
\end{tabular}

A temperatura máxima foi afetada pela radiação solar externa e pela transmissividade da cobertura a onda curta, ficando entre os 6 primeiros em ordem de importância (Tabela 8). Desta maneira, técnicas de sombreamento, 
como o uso de telas "sombrite" e malhas refletoras associadas ao manejo da ventilação podem permitir um melhor controle das altas temperaturas, comuns em casas-de-vegetação no Brasil.

O grande efeito da temperatura externa é explicado pela boa ventilação e pelas altas perdas de energia através da cobertura da casa-de-vegetação, na condição de referência, o que permite uma reação rápida da temperatura do ar interna em função da temperatura do ar externa.

A alta sensibilidade da temperatura do ar ao coeficiente de extinção demonstra a forte relação entre radiação e o balanço de energia no ar da casade-vegetação (Tabela 8). Além de alterar o próprio balanço de energia no dossel, o coeficiente de extinção afeta a quantidade de radiação que atinge o solo. No presente trabalho foi usado um $K$ médio para o dossel, mas futuros trabalhos devem levar em conta modelos mais completos de interceptação da radiação, que considerem, por exemplo, diferenças entre radiação difusa e direta e a variação do ângulo de incidência.

O percentual de abertura das cortinas foi outro fator que mostrou influência sobre a temperatura do ar interna, especialmente sobre a temperatura do ar máxima, o que evidencia a importância da ventilação na dissipação do excesso de energia na casa-de-vegetação. Isso ressalta a necessidade de melhores pesquisas sobre trocas de ar em casas-de-vegetação para as condições nacionais, que são ainda muito escassos.

Pode-se notar pela Tabela 8 que, dentre os elementos estruturais, a altura do pé-direito da casa-de-vegetação foi a que mais afetou a temperatura do ar. Foi observada uma redução nos valores médio e máximo, respectivamente, em $0,36^{\circ} \mathrm{C}$ e $0,44^{\circ} \mathrm{C}$ em relação ao valor de referência, com o aumento da altura do pé-direito. Tal prática tem sido observada em casas-devegetação desenvolvidas recentemente, com pés-direitos de até $5 \mathrm{~m}$, com o objetivo de evitar temperaturas do ar altas pelo aumento da área de aberturas laterais, devido à maior altura, melhorando as trocas de calor pela ventilação. 
A umidade relativa do ar média interna foi afetada principalmente pela umidade relativa externa (URe), coeficiente de extinção, percentual de abertura das cortinas, temperatura do ar externa e transmissividade de onda longa (Tabela 8). Estes fatores estão diretamente ligados ao balanço de massa (URe e $\left.P a b, \tau_{O L}\right)$ e a temperatura do ar interna $(K, T e)$, que altera a pressão de saturação de vapor d'água usado para calcular a umidade relativa do ar. Observa-se pela Tabela 8 que os mesmos fatores são importantes para a temperatura mínima, mas em diferente ordem.

Os demais elementos analisados ( $h s$, coeficiente $A$ para $K c$, altura do arco, largura e comprimento da casa-de-vegetação, coeficientes $a$ e $b$ para calor latente, e velocidade do vento externa) mostraram uma influência variável de acordo com a saída analisada (temperatura do ar mínima, média ou máxima, umidade relativa do ar mínima ou média), indicando uma alternância de importância em função de outros parâmetros, que podem variar ao longo da simulação (ex.: radiação solar, velocidade do vento, radiação emitida pela atmosfera etc). Estes apresentaram variações absolutas pequenas em relação ao valor de referência (entre $-0,54^{\circ} \mathrm{C}$ e $0,27^{\circ} \mathrm{C}$ para temperatura do ar e entre $2,85 \%$ a $0,34 \%$ para umidade relativa do ar). Erros na determinação destes fatores gerariam variações pequenas no resultado geral do modelo, mas diferenças grandes pontualmente, dependendo da interação com outros fatores como manejo das cortinas, radiação solar global, velocidade do vento etc. Assim, a precisão nos dados seria mais importante em modelos interessados na variação do microclima em curto prazo (ex.: próxima meia hora, próxima hora) como em softwares de controle ambiental. Para estimativas em longo prazo (ex.: comportamento ao longo do mês, do ano), pequenos erros nestes coeficientes poderiam ser tolerados, sem grandes prejuízos nos resultados. 


\subsection{COMPARAÇÃO COM DADOS DE CAMPO}

A variação da temperatura e umidade relativa do ar interna, simuladas e medidas, são apresentadas nas figuras Figura 14 e Figura 15, para a condição de casa-de-vegetação fechada (10/11/1999) e aberta durante o dia (23/11/1999), respectivamente. Mesmo sem grande proximidade nos valores, pode-se notar uma similaridade nos comportamento das curvas simuladas e medidas, tanto da temperatura como da umidade relativa do ar. Este comportamento justifica-se uma vez que os coeficientes do modelo não foram levantados na casa-de-vegetação testada, mas obtidos da literatura.

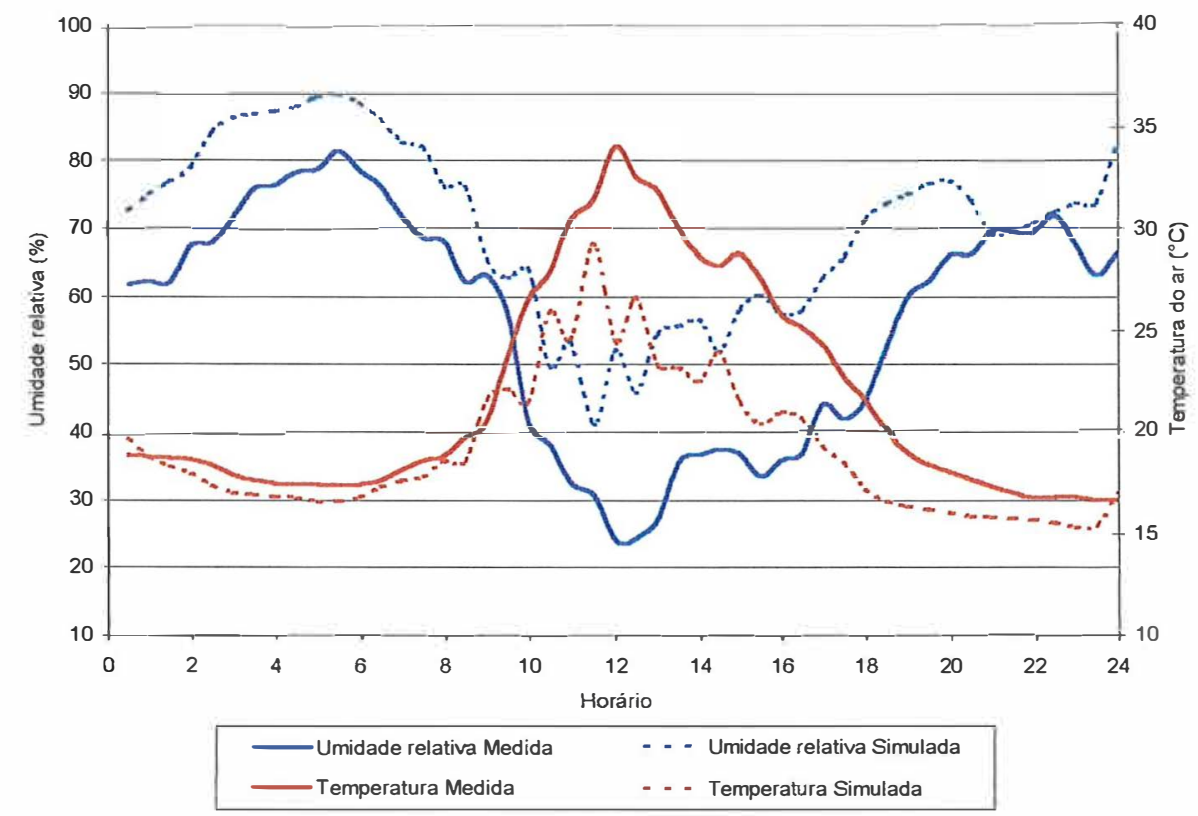

Figura 14. Temperatura e umidade relativa do ar interna, simulada e medida, para a condição de casa-de-vegetação com cortinas fechadas (10/11/1999). 


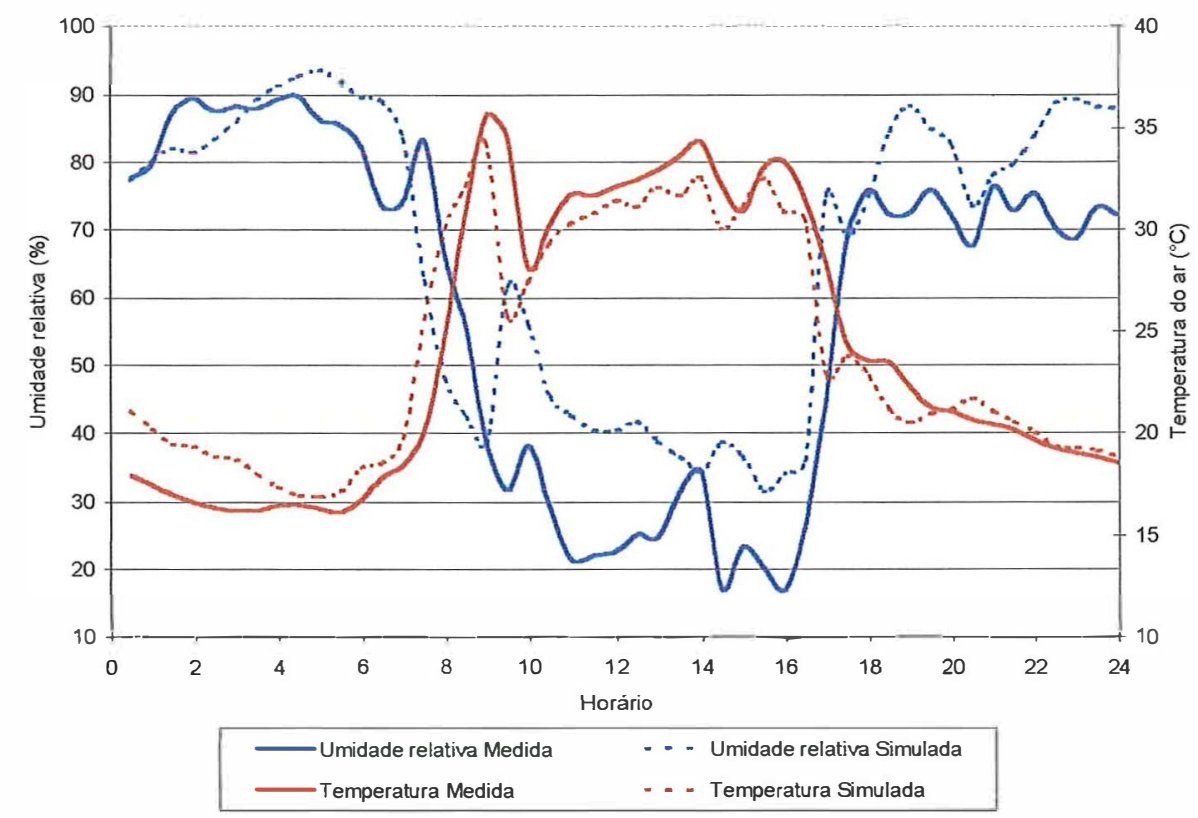

Figura 15. Temperatura e umidade relativa do ar interna, simulada e medida, para a condição de casa-de-vegetação com cortinas abertas (23/11/1999).

O erro médio da temperatura do ar simulada em relação à medida foi de $2,57^{\circ} \mathrm{C}$ e $0,04^{\circ} \mathrm{C}$ (Tabela 9), respectivamente, para casa-de-vegetação com cortinas fechadas e abertas durante o dia. O maior erro para a estufa fechada pode indicar divergências nos valores de transmissividade de onda curta e onda longa da cobertura utilizados no modelo. A ventilação tende a aproximar as temperaturas do ar, interna e externa, na casa-de-vegetação com cortinas abertas, fazendo com que as características da cobertura tomem maior importância com as cortinas fechadas, modificando o balanço de radiação e, conseqüentemente, o comportamento da temperatura do ar. 
Tabela 9. Regressão linear entre resultados simulados e medidos, para casade-vegetação com cortinas fechadas e abertas. Coeficiente angular $e$ coeficiente de determinação da $\left(R^{2}\right)$ reta $1: 1$ do ajuste entre dados simulados e medidos.

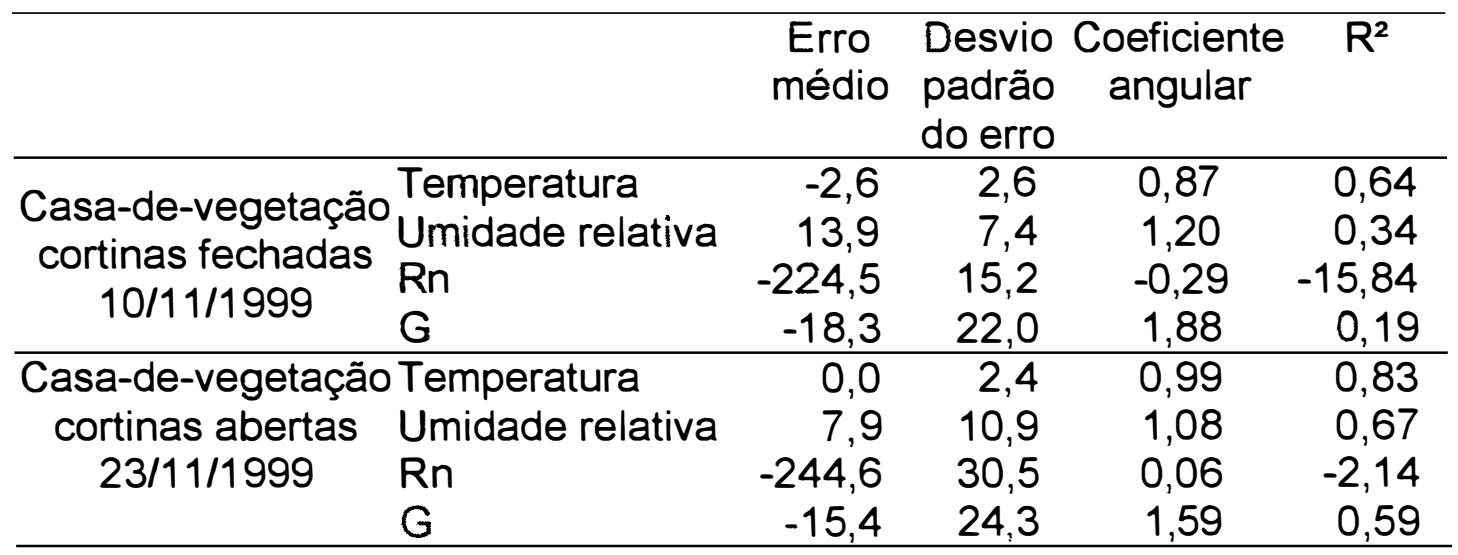

As retas de ajuste 1:1 entre as temperaturas do ar simuladas e medidas (Figura 16 a e b) mostraram que o modelo subestimou a temperatura na casade-vegetação. Os coeficientes de determinação foram relativamente altos, principalmente na casa-de-vegetação aberta, indicando, possivelmente, que haja necessidade apenas de uma calibração dos coeficientes do modelo. As retas de melhor ajuste mostram uma tendência de comportamento linear entre simulado e medido, notado pelos altos valores de $R^{2}(0,84$ e 0,89 , respectivamente para casa-de-vegetação com cortinas fechadas e abertas).

O mesmo pode ser verificado com a umidade relativa do ar (Figura $16 \mathrm{ce}$ d), com uma tendência de comportamento linear entre os dados medidos e simulados, observado pelos altos valores de $\mathrm{R}^{2}$ para as retas de melhor ajuste $(0,85$ e 0,82 para casa-de-vegetação com cortinas fechadas e abertas, respectivamente). O modelo forneceu melhores estimativas em casa-devegetação com cortinas abertas (Tabela 9), demonstrado pelo valor de coeficiente angular da reta 1:1 próximo mais próximo de 1 e pelo maior valor de $\mathrm{R}^{2}(0,7)$ em comparação com a casa-de-vegetação com cortinas fechadas (coeficiente angular $=1,2$ e $R^{2}=0,3$ ). Isso pode estar associado ao uso de um valor não adequado de $\mathrm{No}$, que computa as trocas de ar quando a casa-de- 
vegetação está fechada, e conseqüentemente, influenciando o balanço de vapor d'água nessa condição.

Em geral, o modelo superestimou a umidade relativa, com valores simulados de $13 \%$ e $7,89 \%$ acima do medido, em média, indicando que a condição de campo era mais eficiente nas trocas de ar que a simulada. Isso pode ser expresso com valores maiores de $A c w^{0,5}$, que indicam casas-devegetação mais eficientes na ventilação natural.

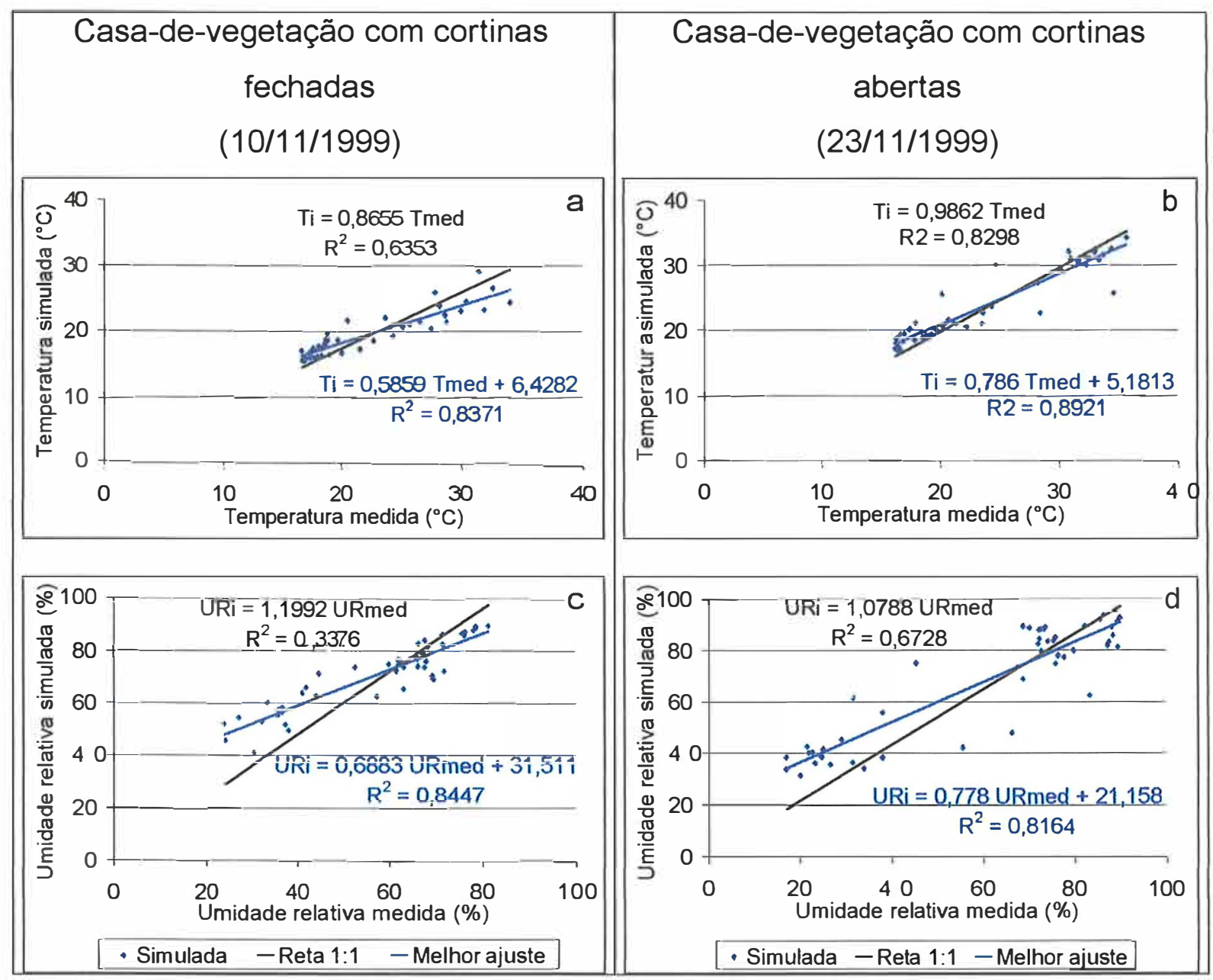

Figura 16. Retas de ajuste entre temperatura e umidade relativa do ar, estimada e simulada, para casa-de-vegetação com cortinas fechadas (10/11/1999) e abertas (23/11/1999). (Ti e URi = temperatura e umidade relativa do ar interna simulada; Tmed e URmed = temperatura e umidade relativa do ar medida na casa-de-vegetação). 
Observa-se na Figura 17, de radiação líquida (Rn), que o comportamento do modelo é semelhante ao medido, porém com um deslocamento na curva. As retas de melhor ajuste (Figura 18 ) indicam um bom ajuste, verificado pelos altos valores de $R^{2}(0,94$ e 0,95 , respectivamente para estufa com cortinas fechadas e abertas), mas com uma defasagem ao redor de $-230 \mathrm{~W} \mathrm{~m}^{2}$ nas estimativas, notado pelo coeficiente linear da equação. Uma maior transmissividade de onda longa da cobertura pode favorecer o balanço de energia, aproximando os valores. Como não havia disponibilidade da transmissividade real do filme de PVC utilizado, foi usado o valor obtido por Wang et al. (1999), e que pode ter diferido das empregadas no teste, gerando as diferenças entre os valores simulado e medido.

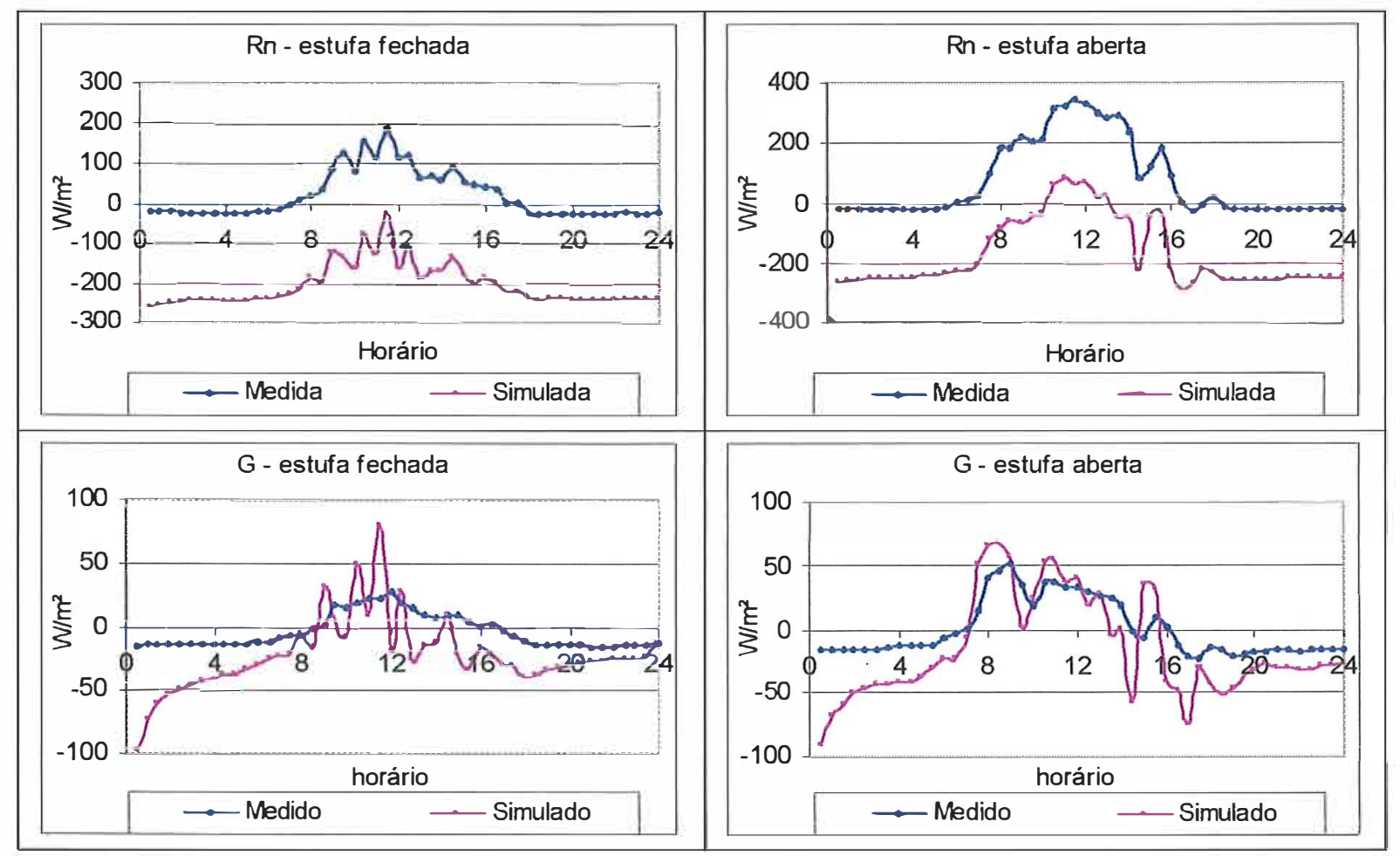

Figura 17. Variação do fluxo de calor no solo $\left(G, W \cdot m^{-2}\right)$ e da radiação líquida $\left(\mathrm{Rn}, \mathrm{W} \cdot \mathrm{m}^{-2}\right)$ ao longo do dia em casa-de-vegetação com cortinas fechadas (10/11/1999) e abertas (23/11/1999). 


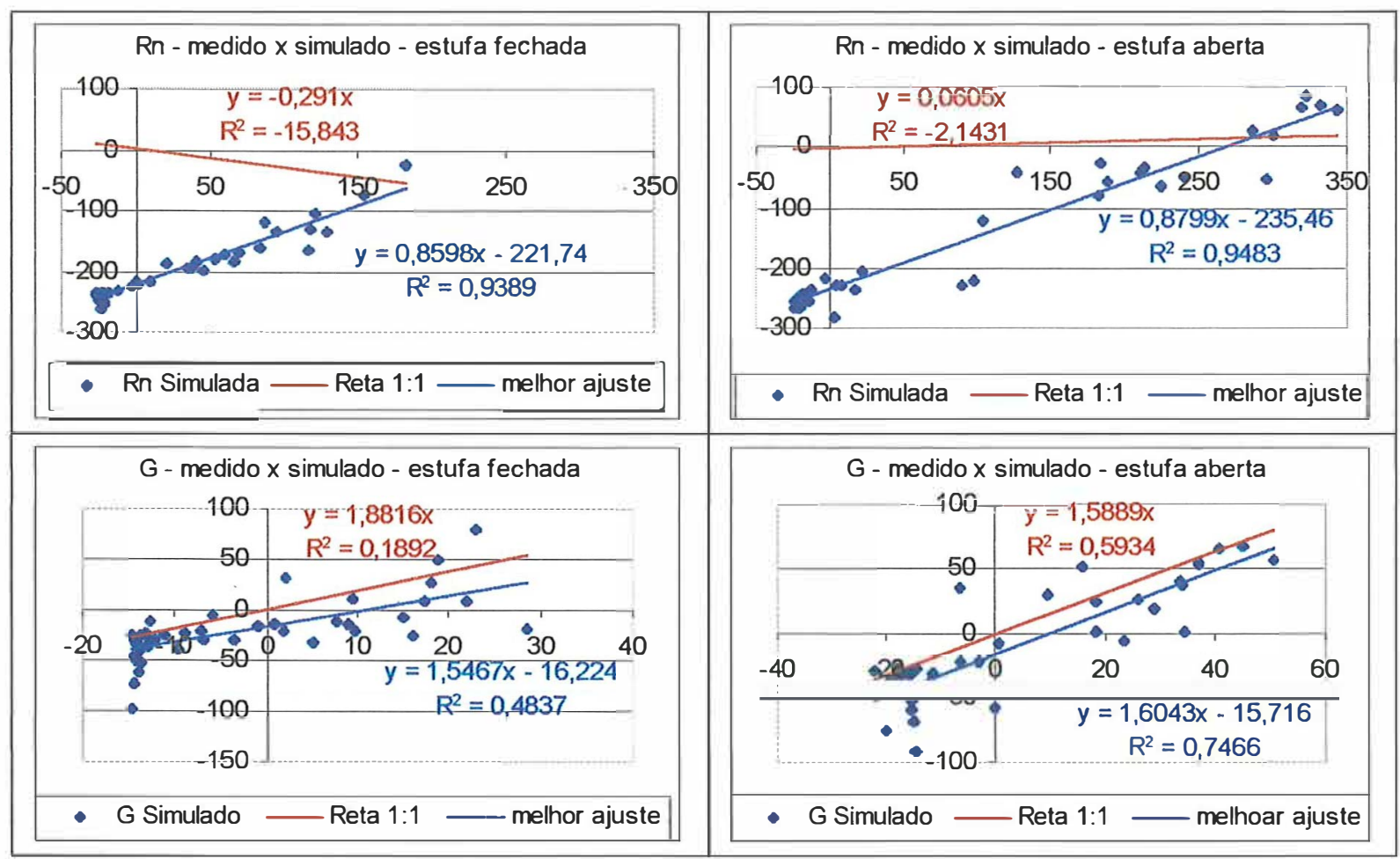

Figura 18. Comparação entre valores simulados e medidos de fluxo de calor no solo $\left(G, W . m^{-2}\right)$ e da radiação líquida $\left(R n, W . m^{-2}\right)$ em casa-devegetação com cortinas fechadas (10/11/1999) e abertas (23/11/1999).

O fluxo de calor no solo simulado (G) também demonstrou um comportamento similar ao medido (Figura 17), porém com uma dispersão maior entre os valores. Os menores valores de $\mathrm{R}^{2}$ para as regressões de melhor ajuste entre valores estimados e medidos $(0,5$ e 0,7, respectivamente para casa-de-vegetação com cortinas fechadas e abertas) (Figura 18) podem estar associados também a divergências nas características radiométricas da cobertura plástica. Outro fator que pode ter contribuído para as diferenças foi utilização de uma única temperatura para o perfil do solo no início da simulação. Devido ao grande número de camadas utilizadas (1000), o solo toma um tempo maior para atingir uma temperatura de equilíbrio em comparação com o ar, gerando as maiores diferenças no início da simulação e observadas na Figura 17. Pode-se minimizar este efeito executando o modelo com os dados iniciais 
até que a temperatura do solo deixe de exibir grandes diferenças entre um passo de tempo e outro. Somente após esse equilíbrio a simulação propriamente dita seria iniciada.

Mesmo utilizando coeficientes levantados da literatura, o modelo gerou um comportamento semelhante na temperatura e umidade relativa do ar, radiação líquida e fluxo de calor no solo, entre valores simulados e medidos, indicando que existe, possivelmente, a necessidade apenas de calibração desses coeficientes (como condutividade térmica, calor específico do solo, refletância do solo à radiação de onda curta, transmissividade da cobertura à radiação cão de onda longa e onda curta etc).

\subsection{DESCRIÇÃO dO PROGRAMA DESENVOLVIDO}

Na Figura 19 é apresentada a tela inicial do programa desenvolvido para a resolução do modelo, denominado de ESTUFA. Nela é possível entrar com o tempo de simulação, intervalo de saída dos resultados e passo de tempo $(\Delta t)$. Foi incorporada também a opção de estimar os dados meteorológicos externos a partir de medidas mais simplificadas (temperatura do ar máxima e mínima, radiação solar máxima, pressão parcial de vapor média e velocidade do vento média), além do uso de arquivo de dados. Em muitos locais não há disponibilidade do curso diário dos elementos meteorológicos, geralmente obtidos de estações meteorológicas automáticas, sendo necessário o uso de estimavas. 


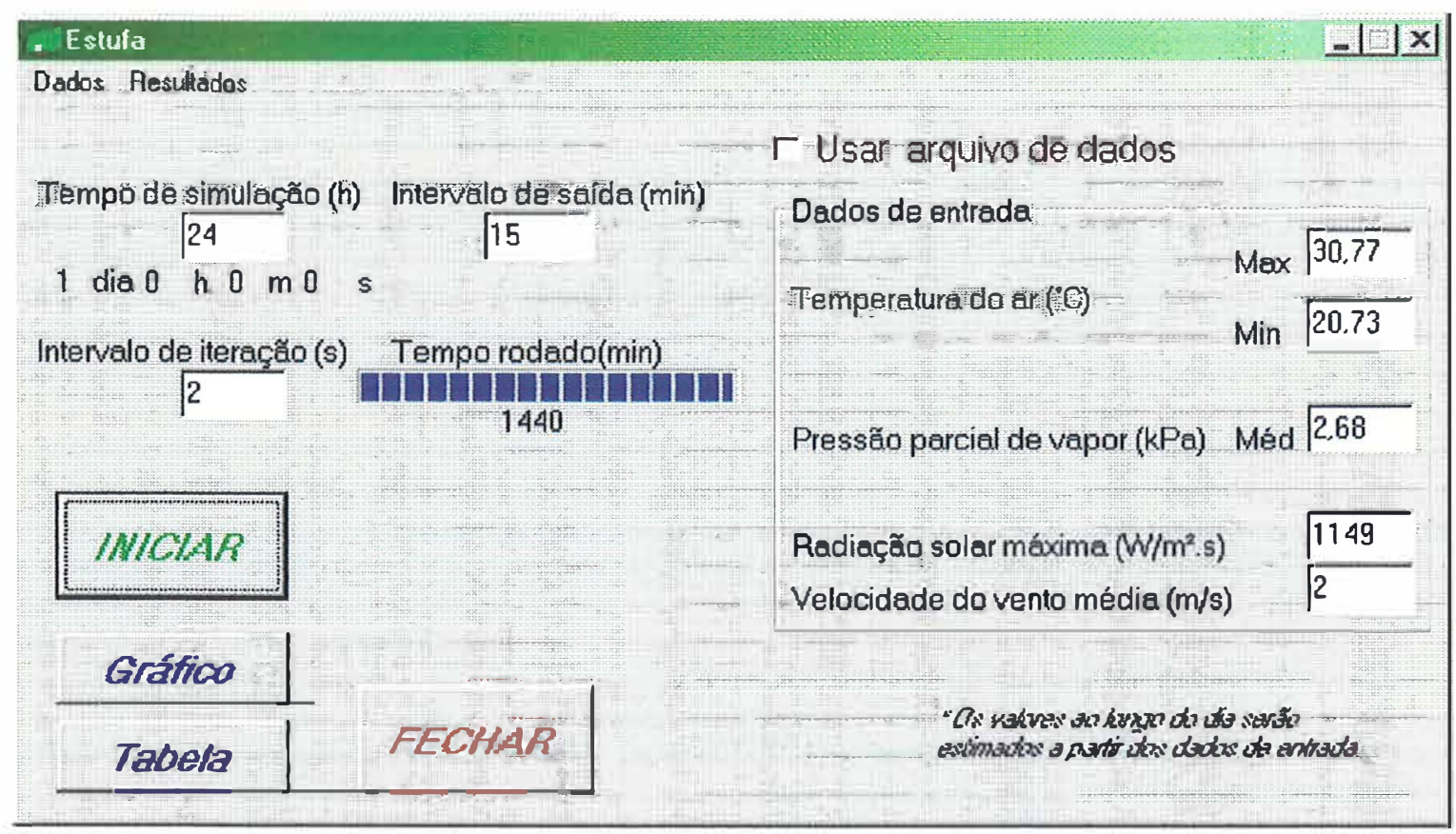

Figura 19. Tela inicial do programa de simulação.

A estimativa da temperatura do ar externa, a partir dos seus valores máximo e mínimo, foi feito através de ajuste para uma curva senoidal, com a temperatura máxima ocorrendo às 14 horas. O curso da radiação solar também foi ajustado para uma curva senoidal, com valor máximo ocorrendo ao meio-dia e nulo durante a noite, entre 18 e 6 horas. A umidade relativa foi obtida através da temperatura do ar e pressão parcial de vapor médio. A forma de estimativa dos elementos meteorológicos externos ainda necessita de melhorias como a incorporação do efeito da nebulosidade no cálculo da radiação solar, e variação da pressão parcial de vapor para o cálculo da umidade relativa do ar.

Na Figura 20 é apresentada a tela de entrada para os dados e coeficientes da casa-de-vegetação, onde são especificadas as características da estrutura (altura, largura etc), do material de cobertura, taxa de ventilação natural e manejo das cortinas laterais. 


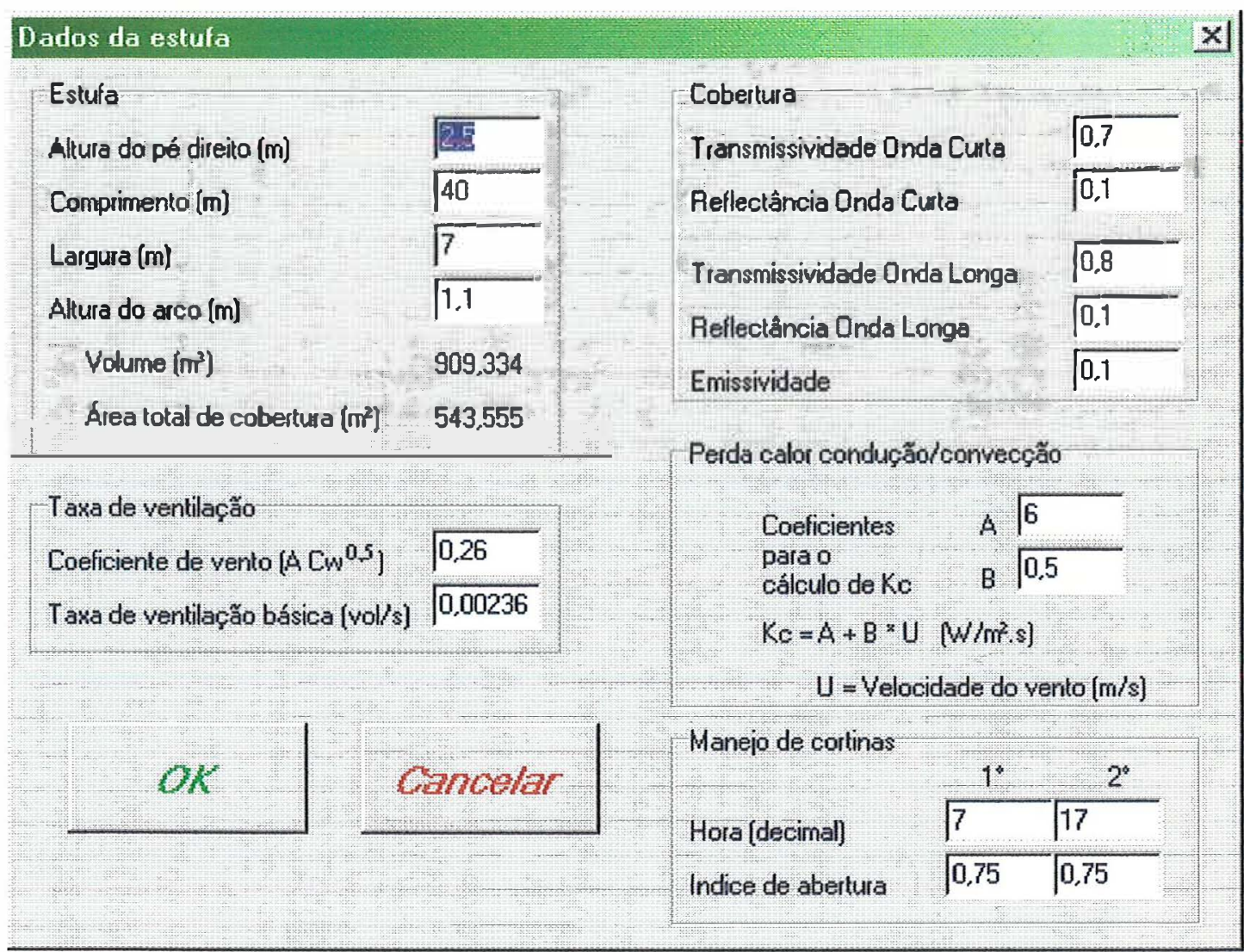

Figura 20. Tela do programa ESTUFA para entrada de dados sobre a casa-devegetação.

A tela de entrada dos dados e coeficientes do solo, cultura e ar são apresentados na Figura 21.

Os resultados da simulação são apresentados na janela "Tabela" (Figura 22) com os valores da variação ao longo do tempo da temperatura e umidade relativa do ar e temperatura na superfície do solo, além das densidades de fluxo de energia dos principais componentes do sistema. Os resultados podem ser salvos na forma de um arquivo texto e utilizados, posteriormente, em planilhas eletrônicas. A janela "Gráfico" (Figura 23) apresenta a variação da temperatura e umidade relativa do ar, interna e externa a casa-de-vegetação, ao longo do tempo de simulação. 


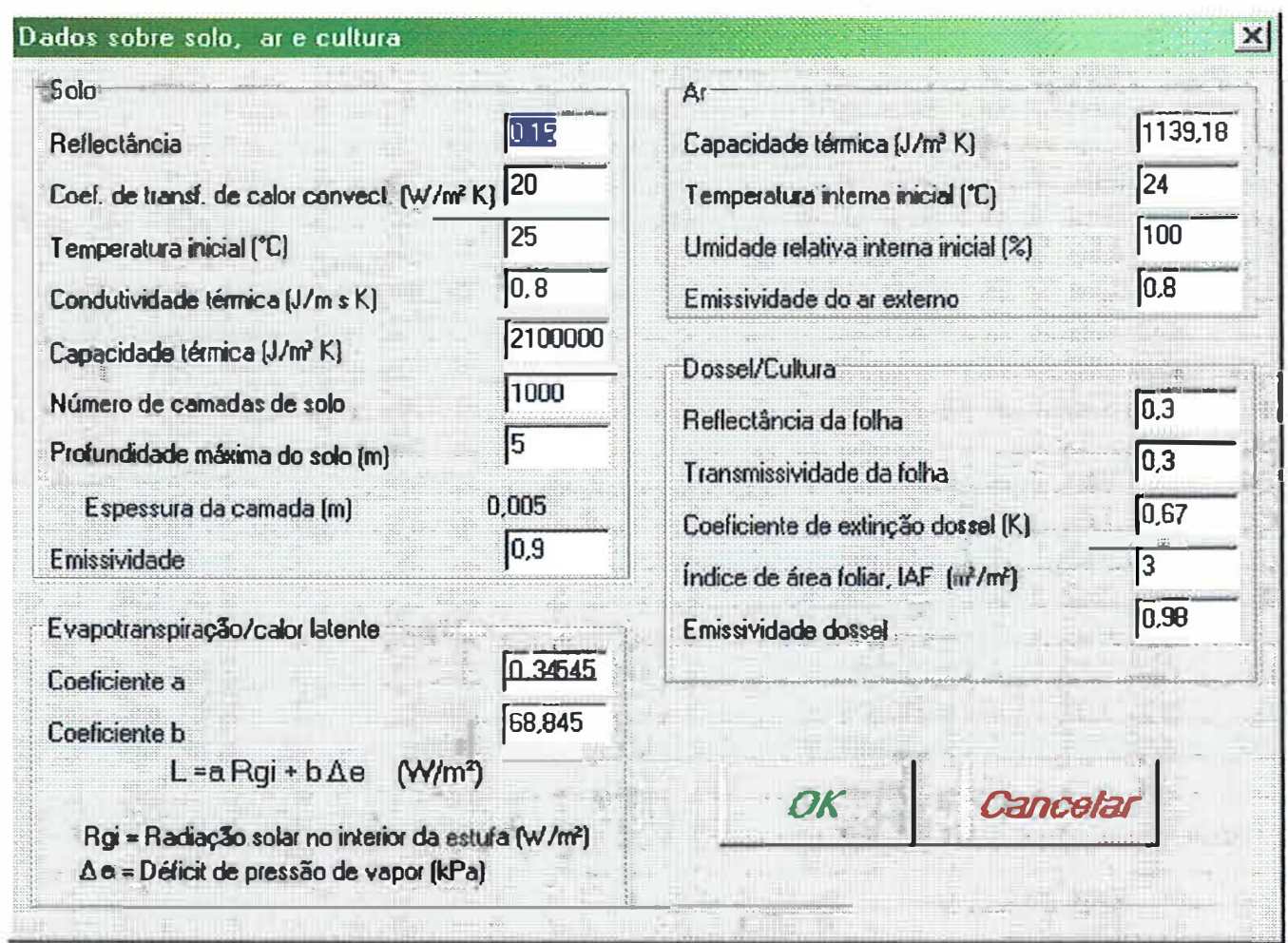

Figura 21. Tela do programa para entrada de dados sobre o solo, cultura e ar na casa-de-vegetação.

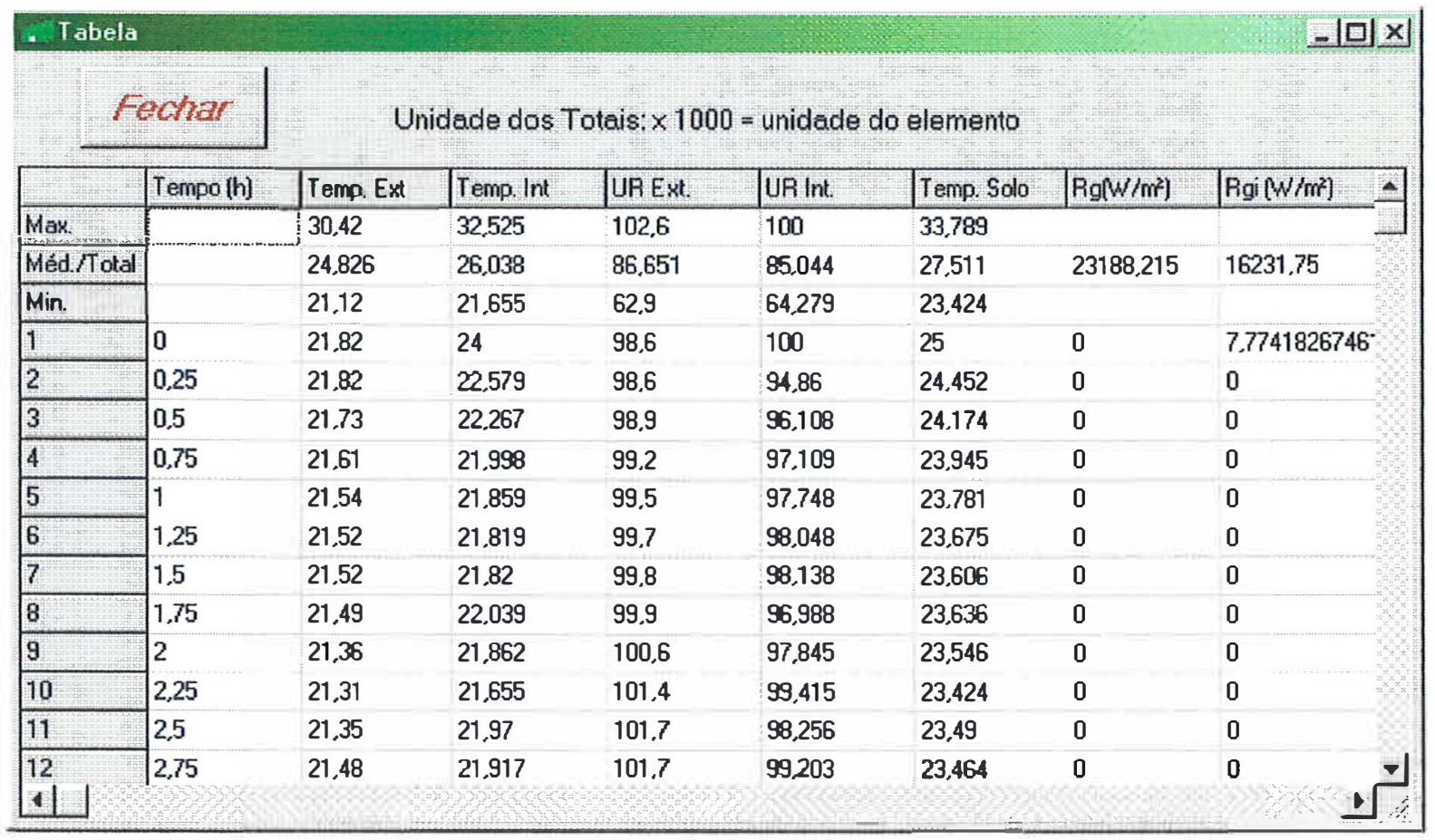

Figura 22. Tabela de resultados do programa de simulação. 


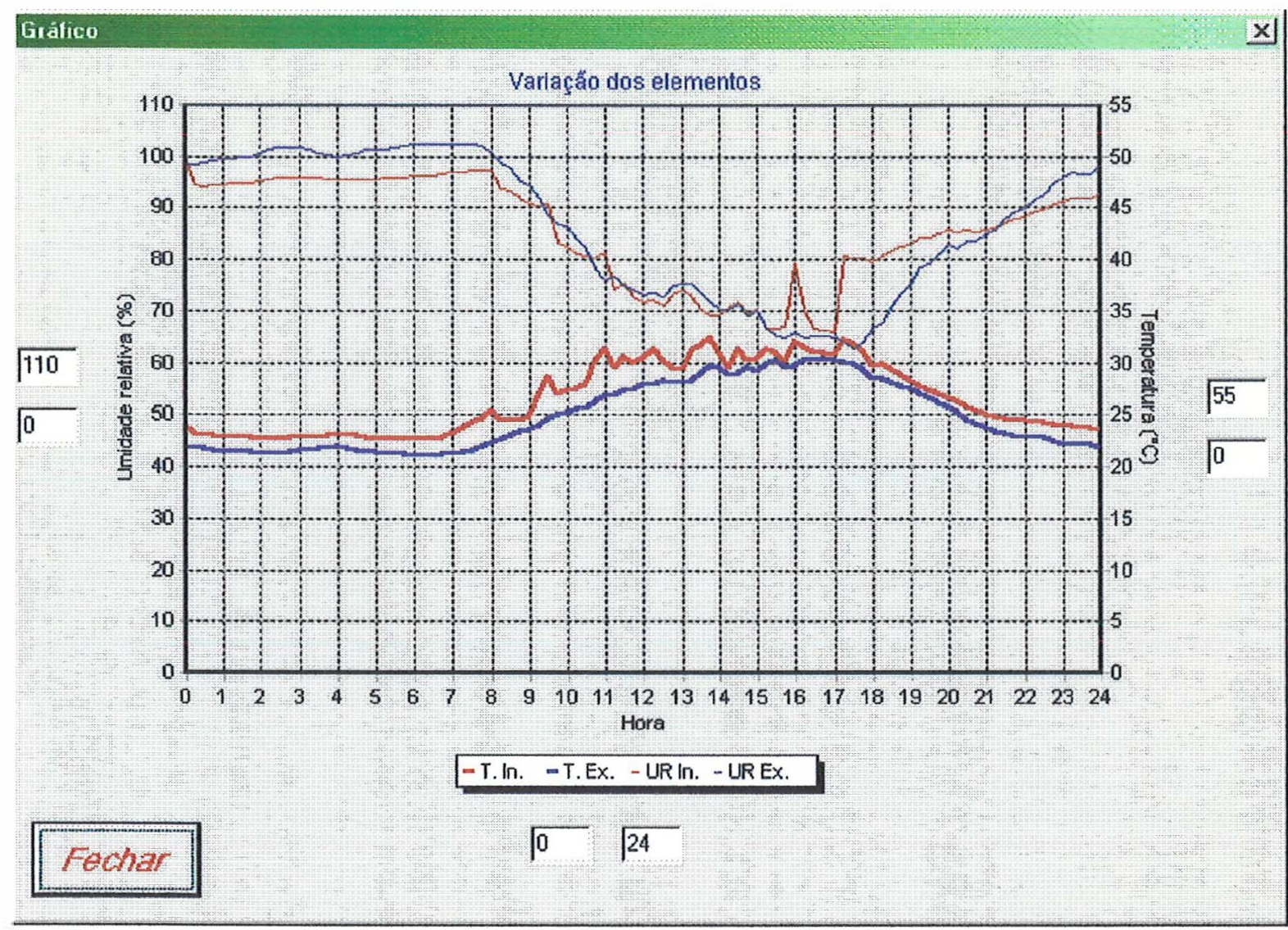

Figura 23. Gráfico gerado pelo programa de simulação como a variação da temperatura e umidade relativa do ar, interna e externamente a casade-vegetação.

A eficiência de computação do modelo foi considerada bastante satisfatória. Assim, utilizando-se um computador Pentium II 266MHz, com 64MB de memória RAM, uma simulação de um dia levou aproximadamente 6 segundos para ser executado. Considerando a possibilidade de redução do número de camadas do solo (no trabalho foram usadas 1000) e um aumento no passo de tempo (no trabalho foi usado um $\Delta t=2 \mathrm{~s}$ ), esse tempo pode ser reduzido significativamente, permitindo, em futuros trabalhos, simulações com maior número de dados e implementação de rotinas de otimização do microclima em casas-de-vegetação. Como exemplo, a mesma simulação 
executada com 100 camadas de solo e passo de tempo de 4 segundo levou menos de 1 segundo para ser realizado. 


\section{CONCLUSÕES}

A partir dos resultados, pode-se concluir que o modelo ESTUFA, desenvolvido para estimar os elementos climáticos do microclima em casas-devegetação, mostrou-se condizente com os resultados da literatura. As comparações com dados de campo mostraram um comportamento similar na variação da temperatura e umidade relativa do ar, indicando a necessidade de ajustes nos coeficientes. O modelo possibilitou a visualização dos fluxos formadores do microclima na casa-de-vegetação e importância de cada um, o que pode permitir um melhor direcionamento de futuras pesquisas.

Os fatores que mais afetaram a temperatura do ar simulada foram: temperatura do ar externa; coeficiente de extinção do dossel; percentual de abertura das cortinas; e transmissividade da cobertura a radiação de onda longa. A umidade relativa do ar simulada foi mais afetada pela umidade relativa do ar externa, coeficiente de extinção, percentual de abertura das cortinas e temperatura do ar externa.

O programa desenvolvido para resolução do modelo mostrou-se eficiente, permitindo a análise de todos os coeficientes e uso de arquivos com os dados meteorológicos externos, e fornecendo a comportamento ao longo do tempo da temperatura e umidade relativa do ar interna e de todos os fluxos de energia do balanço. 


\section{ANEXO}

RESULTADOS DAS SIMULAÇÕES PARA ANÁLISE DE SENSIBILIDADE 
Tabela 1. Temperatura e umidade relativa do ar geradas pela análise de sensibilidade.

\begin{tabular}{|c|c|c|c|c|c|c|c|}
\hline $\begin{array}{l}\text { Elemento } \\
\text { analisado }\end{array}$ & Intervalo & $\begin{array}{r}\text { Tem } \\
\text { minima }\end{array}$ & $\begin{array}{l}\text { eratur } \\
\text { média }\end{array}$ & $\begin{array}{l}\left({ }^{\circ} \mathrm{C}\right) \\
\text { máxima }\end{array}$ & minima & $\begin{array}{l}\text { UR }(\%) \\
\text { média }\end{array}$ & náxima \\
\hline Valor de referé & ência & 20,6 & 25,7 & 32,2 & 54,8 & 82,3 & 100 \\
\hline & Inferior & 21,0 & 25,9 & 32,4 & $\overline{55,4}$ & 82,4 & 100 \\
\hline Altur & Superior & 20,4 & 25,3 & 31,8 & 52,0 & 81,7 & 100 \\
\hline Comprimento da & Inferior & 20,6 & 25,5 & 32,0 & 53,3 & 82,0 & 100 \\
\hline casa-de-ı & Superior & 20,7 & 25,5 & 32,0 & 53,3 & 81,8 & 100 \\
\hline Largura da casa-de & Inferior & 20,6 & 25,4 & 31,8 & 51,9 & 81,8 & 100 \\
\hline vegetação & Superior & 20,7 & 25,7 & 32,2 & 54,6 & 82,0 & 100 \\
\hline Alture de aren & Inferior & 20,8 & 25,6 & 32,0 & 53,3 & 81,9 & 100 \\
\hline Altura do arco & Superior & 20,6 & 25,5 & 32,0 & 53,3 & 81,9 & 100 \\
\hline Transmissividade & Inferior & 20,7 & 25,7 & 32,3 & 52,2 & 81,0 & 100 \\
\hline de O & Superior & 20,7 & 25,4 & 31,5 & 54,7 & 82,8 & 100 \\
\hline Transmiss & Inferior & 21,8 & 26,2 & 32,4 & 52,6 & 79,7 & 100 \\
\hline & Superior & 20,6 & 25,5 & 31,9 & 53,4 & 82,2 & 100 \\
\hline$A$ nara $K_{c}$ & Inferior & 20,9 & 25,7 & 32,0 & 53,3 & 81,6 & 100 \\
\hline Coer. A para AC & Superior & 20,5 & 25,5 & 32,0 & 53,4 & 82,1 & 100 \\
\hline & Inferior & 20,7 & 25,9 & 32,7 & 57,0 & 82,7 & 100 \\
\hline & Supe & 20,7 & 25,4 & 31,7 & 51,7 & 81,6 & 100 \\
\hline hs & Inferior & 20,2 & 25,4 & 32,0 & 53,4 & 82,6 & 100 \\
\hline & Superior & 20,8 & 25,6 & 32,0 & 53,3 & 81,7 & 100 \\
\hline Coof a naral & Inferior & 20,7 & 25,7 & 32,3 & 52,4 & 81,2 & 100 \\
\hline Wuel. a pald L & Superior & 20,7 & 25,5 & 31,7 & 54,3 & 82,5 & 100 \\
\hline 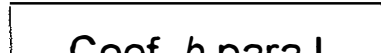 & Inferior & 20,8 & 25,7 & 32,3 & 52,3 & 81,2 & 100 \\
\hline Vuel. D pald L & Superior & 20,7 & 25,5 & 31,7 & 54,3 & 82,5 & 100 \\
\hline Coef. de & Inferior & 23,3 & 27,2 & 33,5 & 50,3 & 76,1 & 100 \\
\hline extinção(K) & Superior & 18,9 & 24,4 & 31,1 & 55,4 & 85,9 & 100 \\
\hline Pab & Inferior & 20,5 & 26,9 & 35,4 & 74,7 & 88,2 & 100 \\
\hline 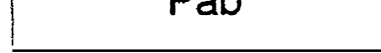 & & 20,8 & 25,5 & 31,9 & 52,5 & 81,6 & 100 \\
\hline $\mathrm{Rg}$ & Inferi & 20,7 & 25,4 & 31,5 & 53,7 & 82,1 & 100 \\
\hline & Supe & 20,7 & 25,7 & 32,5 & 52,9 & 81,6 & 100 \\
\hline To & Inferior & 17,6 & 21,3 & 26,5 & 52,5 & 80,3 & 100 \\
\hline 10 & Superior & 23,9 & 29,9 & 37,4 & 54,5 & 83,5 & 100 \\
\hline UR & Inferior & 20,1 & 25,1 & 31,7 & 44,5 & 70,8 & 100 \\
\hline & Superior & 20,6 & 25,7 & 32,3 & 61,9 & 88,0 & 100 \\
\hline$U$ & Inferior & 20,7 & 25,6 & 32,1 & 54,1 & 82,0 & 100 \\
\hline & Superior & 20,7 & 25,5 & 31,9 & 52,8 & 81,8 & 100 \\
\hline
\end{tabular}


Tabela 2. Variação absoluta da temperatura e umidade relativa do ar simuladas em relação ao valor de referência.

\begin{tabular}{|c|c|c|c|c|c|c|c|}
\hline \multirow{2}{*}{$\begin{array}{c}\text { Elemento } \\
\text { analisado } \\
\end{array}$} & \multirow[t]{2}{*}{ Intervalo } & \multicolumn{3}{|c|}{ Temperatura $\left({ }^{\circ} \mathrm{C}\right)$} & \multicolumn{3}{|c|}{ UR (\%) } \\
\hline & & mínima & média & máxima & mínima & média & aáxim \\
\hline \multirow{2}{*}{ Altura do pé direito } & Inferior & 0,4 & 0,2 & 0,2 & 0,6 & 0,2 & 0,0 \\
\hline & Superior & $-0,3$ & $-0,4$ & $-0,4$ & $-2,7$ & $-0,6$ & 0,0 \\
\hline \multirow{2}{*}{$\begin{array}{c}\text { Comprimento da } \\
\text { casa-de-vegetação }\end{array}$} & Inferior & 0,0 & $-0,1$ & $-0,2$ & $-1,4$ & $-0,3$ & 0,0 \\
\hline & Superior & 0,1 & $-0,1$ & $-0,2$ & $-1,4$ & $-0,4$ & 0,0 \\
\hline \multirow{2}{*}{$\begin{array}{l}\text { Largura da casa-de- } \\
\text { vegetação }\end{array}$} & -Inferior & 0,0 & $-0,3$ & $-0,5$ & $-2,9$ & $-0,5$ & 0,0 \\
\hline & Superior & 0,1 & 0,0 & 0,0 & $-0,2$ & $-0,2$ & 0,0 \\
\hline \multirow{2}{*}{ Altura do arco } & Inferior & 0,2 & $-0,1$ & $-0,2$ & $-1,4$ & $-0,4$ & 0,0 \\
\hline & Superior & 0,0 & $-0,1$ & $-0,2$ & $-1,5$ & $-0,4$ & 0,0 \\
\hline \multirow{2}{*}{$\begin{array}{c}\text { Transmissividade } \\
\text { de OC }\end{array}$} & Inferior & 0,1 & 0,0 & 0,1 & $-2,6$ & $-1,2$ & 0,0 \\
\hline & Superior & 0,1 & $-0,2$ & $-0,7$ & $-0,1$ & 0,6 & 0,0 \\
\hline \multirow{2}{*}{$\begin{array}{c}\text { Transmissividade } \\
\text { de OL }\end{array}$} & Inferior & 1,2 & 0,5 & 0,2 & $-2,2$ & $-2,6$ & 0,0 \\
\hline & Superior & $-0,1$ & $-0,2$ & $-0,3$ & $-1,3$ & $-0,1$ & 0,0 \\
\hline \multirow{2}{*}{ Coef. A para Kc } & Inferior & 0,3 & 0,0 & $-0,2$ & $-1,5$ & $-0,7$ & 0,0 \\
\hline & Superior & $-0,1$ & $-0,2$ & $-0,2$ & $-1,4$ & $-0,1$ & 0,0 \\
\hline \multirow{2}{*}{$A C w^{0,5}$} & Inferior & 0,1 & 0,2 & 0,4 & 2,2 & 0,4 & 0,0 \\
\hline & Superior & 0,1 & $-0,3$ & $-0,5$ & $-3,1$ & $-0,6$ & 0,0 \\
\hline \multirow{2}{*}{ hs } & Inferior & $-0,4$ & $-0,3$ & $-0,2$ & $-1,4$ & 0,3 & 0,0 \\
\hline & Superior & 0,2 & $-0,1$ & $-0,2$ & $-1,5$ & $-0,5$ & 0,0 \\
\hline \multirow{2}{*}{ Coef. a para L } & Inferior & 0,1 & 0,0 & 0,1 & $-2,4$ & $-1,0$ & 0,0 \\
\hline & Superior & 0,1 & $-0,2$ & $-0,5$ & $-0,5$ & 0,3 & 0,0 \\
\hline \multirow{2}{*}{ Coef. $b$ para L } & Inferior & 0,1 & 0,0 & 0,1 & $-2,5$ & $-1,1$ & 0,0 \\
\hline & Superior & 0,0 & $-0,2$ & $-0,5$ & $-0,5$ & 0,3 & 0,0 \\
\hline \multirow{2}{*}{ Coef. de extinção( $K)$} & Inferior & 2,7 & 1,6 & 1,3 & $-4,5$ & $-6,2$ & 0,0 \\
\hline & Superior & $-1,7$ & $-1,2$ & $-1,2$ & 0,7 & 3,6 & 0,0 \\
\hline \multirow{2}{*}{ Pab } & Inferior & $-0,1$ & 1,2 & 3,2 & 20,0 & 5,9 & 0,0 \\
\hline & Superior & 0,1 & $-0,2$ & $-0,4$ & $-2,2$ & $-0,6$ & 0,0 \\
\hline \multirow{2}{*}{$\mathrm{Rg}$} & Inferior & 0,1 & $-0,3$ & $-0,7$ & $-1,0$ & $-0,1$ & 0,0 \\
\hline & Superior & 0,1 & 0,1 & 0,3 & $-1,8$ & $-0,6$ & 0,0 \\
\hline \multirow{2}{*}{$\mathrm{Te}$} & Inferior & $-3,1$ & $-4,4$ & $-5,7$ & $-2,3$ & $-2,0$ & 0,0 \\
\hline & Superior & 3,2 & 4,2 & 5,2 & $-0,3$ & 1,2 & 0,0 \\
\hline \multirow{2}{*}{ URe } & Inferior & $-0,6$ & $-0,6$ & $-0,6$ & $-10,3$ & $-11,5$ & 0,0 \\
\hline & Superior & 0,0 & 0,1 & 0,1 & 7,2 & 5,7 & 0,0 \\
\hline \multirow[t]{2}{*}{$U$} & Inferior & 0,1 & 0,0 & $-0,1$ & $-0,7$ & $-0,3$ & 0,0 \\
\hline & Superior & 0,1 & $-0,2$ & $-0,3$ & $-2,0$ & $-0,5$ & 0,0 \\
\hline
\end{tabular}


Tabela 3. Variação percentual da temperatura e umidade relativa do ar interna simulada em relação ao valor de referência

\begin{tabular}{|c|c|c|c|c|c|c|c|}
\hline \multirow{2}{*}{$\begin{array}{l}\text { Elemento } \\
\text { analisado }\end{array}$} & \multirow[b]{2}{*}{ Intervalo } & \multicolumn{3}{|c|}{ Temperatura (\%) } & \multicolumn{3}{|c|}{ UR (\%) } \\
\hline & & mínima & média & máxima & mínima & média & máxima \\
\hline \multirow{2}{*}{$\mathrm{Rg}$} & Inferior & 0,3 & $-1,0$ & $-2,2$ & $-1,9$ & $-0,2$ & 0,0 \\
\hline & Superior & 0,3 & 0,2 & 0,8 & $-3,3$ & $-0,8$ & 0,0 \\
\hline \multirow{2}{*}{$\mathrm{Te}$} & Inferior & $-14,9$ & $-17,1$ & $-17,6$ & $-4,2$ & $-2,4$ & 0,0 \\
\hline & Superior & 15,7 & 16,3 & 16,1 & $-0,5$ & 1,5 & 0,0 \\
\hline \multirow{2}{*}{ URe } & Inferior & $-2,8$ & $-2,2$ & $-1,7$ & $-18,7$ & $-14,0$ & 0,0 \\
\hline & Superior & $-0,1$ & 0,3 & 0,3 & 13,1 & 6,9 & 0,0 \\
\hline \multirow{2}{*}{$U$} & Inferior & 0,3 & $-0,1$ & $-0,3$ & $-1,3$ & $-0,3$ & 0,0 \\
\hline & Superior & 0,3 & $-0,6$ & $-1,0$ & $-3,6$ & $-0,6$ & 0,0 \\
\hline
\end{tabular}




\section{REFERÊNCIAS BIBLIOGRÁFICAS}

BAILEY, B.J.; DAY, W. The use of models in greenhouse environmental control. Acta Horticulturae, n.486, p.93-99, 1999.

BAYTORUN, N.; ABAK, K.; TOKGÖZ, H.; ALTUNTAS, Ö. Effect of different greenhouse covering materials on inside climate and on the development of tomato plants. Acta Horticulturae, n.366, p.125-132, 1994.

BOULARD, T.; BAILLE, A. A simple greenhouse climate control model incorporating effects of ventilation and evaporative cooling. Agricultural and Forest Meteorology, v.65, n.3-4, p.145-157, 1993.

BOULARD, T.; MENESES, J.F.; MERMIER, M.; PAPADAKIS, G. The macanisms involved in the natural ventilation of greenhouses. Agricultural and Forest Meteorology, v.79, n.1-2, p.61-77, 1996.

BURIOL, G.A.; SCHNEIDER, F.M.; ESTEFANEL, V.; ANDRIOLO, J.L.; MEDEIROS, S.L.P. Modificaçòes na temperatura mínima do ar causada por estufas de polietileno transparente de baixa densidade. Revista Brasileira de Agrometeorologia, v.1, n.1, p.43-49, 1993.

CAMACHO, M.J.; ASSIS, F.N. DE; MARTINS, S.R.; MENDEZ, M.E.G. Avaliação de elementos meteorológicos em estufa plástica em pelotas, RS. Revista Brasileira de Agrometeorologia, v.3, p.19-24, 1995

CERMEÑO, ZOILO SERRANO. Cultivo de plantas hortícolas em estufa. ed. Lisboa: Litexa-Portugal, SD. 368p. 
CRITTEN, D.L. The evaluation of a computer model to calculate the daily light integral and transmissivity of a greenhouse. Journal of Agricultural Engineering Research, v.28, p.545-563, 1983.

CUNHA, J.B; RUANO, A.E.B.; COUTO, C. Identification of greenhouse climate dynamic models. In: Iternational Conference on Computers in Agriculture, 6, Orlando: ASAE, 1998. p.161-171.

DALMAGO, G.A.; HELDWEIN, A.B.; ESTEFANEL, V.; STRECK, N.A. Estimativa do consumo d'água do tomateiro em uma estufa plástica, a partir da evaporação e do número de folhas por planta. In: Congresso Brasileiro de Agrometeorologia, 10, Piracicaba, 1997. Anais. 1997: Sociedade Brasileira de Agrometeorologia, 1997. p.632-634.

DALSASSO, L.C.M.; HELDWEIN, A.B.; BURIOL, G.A.; SCHNEIDER, F.M.; STRECK, N.A.; DALMAGO, G.A. Consumo d'água do tomateiro tipo salada em estufa plastica. Revista Brasileira de Agrometeorologia, v.5, n.1, p.61-67, 1997

FARIAS, J.R.B.; BERGAMASCHI, H.; MARTINS, S.R.; BERLATO, M.A.; OLIVEIRA, A.C.B. Alterações na temperatura e umidade relativa do ar provodas pelo uso de estufa plástica. Revista Brasileira de Agrometeorologia, v.1, n.1, p.51-62, 1993b.

FARIAS, J.R.B.; BERGAMASHI, H.; MARTINS, S.R. Evapotranspiração no interior de estufas plásticas. Revista Brasileira de Agrometeorologia, v.2, p.17-22, 1994.

FARIAS, J.R.B.; BERGAMASHI, H.; MARTINS, S.R.; BERLATO, M.A Efeito da cobertura plástica de estufa sobre a radiação solar. Revista Brasileira de Agrometeorologia, v.1, n.1, p.31-36, 1993a.

FERNANDES, A.L.T. Monitoramento da cultura do crisântemo em estufa através do uso de lisímetro e estação agrometeorológica automatizada. 
Piracicaba, 1996. 96p. Dissertação (mestrado) - Escola Superior de Agricultura "Luiz de Queiroz", Universidade de São Paulo.

FEUILLOLEY, P.; ISSANCHOU, G. Grenhouse covering materials measurement and modelling of thermal properties using the hot box method, and condensation effects. Journal of Agricultural Engineering Research, v.65, p.129-142, 1996.

FOLEGATTI, M. V. et al. Efeitos da cobertura plástica sobre os elementos meteorológicos e evapotranspiração da cultura de crisântemo em estufa. Revista Brasileira de Agrometeorologia, v.5, n.2, p.155-163, 1997

FULLER, R.J.; MEYER, C.P.; SALE, P.J.M. Validation of a dynamic model for predicting energy use in greenhouse. Journal of Agricultural Engineering Research, v.38, p.1-14, 1987.

FURLAN, R. A. Consumo de água pela cultura do crisântemo envasado, cultivar Puritan, sob condições de estufa. Piracicaba, 1996. 65p. Dissertação (mestrado) - Escola Superior de Agricultura "Luiz de Queiroz", Universidade de São Paulo.

GARNAUD, J. C. Intensification of horticultural crop production in the medirranean basin, by protected cultivation. ed. Roma: FAO, 1974. p.

GOTO, R. Estufas plásticas: Manejo. In: KEIGO, M; IAMAMOTO, M. M.; RICCI, A. P. SEALQ: Manejos alternativos na agricultura. Piracicaba: ESALQ, 1993. p.1-27.

HANAN, J.J. Greenhouses: Advanced technology for protected horticulture. Boca Raton, Florida: CRC Press, 1998. 684p.

HELDWEIN, A.B.; STRECK, N.A.; BURIOL, G.A.; SCHNEIDER, F.M.; ESTEFANEL, V.; DALMAGO, G.A. Efeito da cobertura de estufa plástica sobre a temperatura mínima do ar. In: Congresso Brasileiro de Agrometeorologia, 9, Campina Grande, 1996. Anais. 1996: Sociedade Brasileira de Agrometeorologia, 1996. p.304-306. 
IOSLOVICH, I.; SEGINER, I. Aproximate seasonal optimization of the greenhouse environment for a multi-state-variable tomato model. Transactions of the ASAE, v.41, n.4, p.1139-1149, 1998.

IOSLOVICH, I.; SEGINER, I. Normalized costate variable for seasonal optimization of greenhouse tomato production. Acta Horticulturae, n.417, p.87-97, 1996.

JARVIS, W. R.. Managing diseases in greenhouse crops. ed. Saint Paul: APS Press, 1993. 288p.

JOLLIET, O. HORTITRANS, a model for predicting and optimizing humidity and transpiration in greenhouses. Journal of Agricultural Engineering Research, v.57, p.23-37, 1994.

JOLLIET, O; BAILEY, B.J. The effect of climate on tomato transpiration in greenhouse: measurements and models comparation. Agricultural and Forest Meteorology, v.58, p.43-62, 1992.

JONES, H. G.. Plants and microclimate: A quantitative approach to enviromental plant physiology. 2ed. Cambridge: Cambridge University Press, 1994. 428p.

JONES, J.W.; HWANG, Y.K.; SEGINER, I. Simulation of greenhouse crops, environments and control, Acta Horticulturae, n.399, p.73-81, 1995.

JONES, P.; JONES, J.W.; HWANG, Y. Simulation for determining greenhouse temperature setpoints. Transactions of the ASAE, v.33, n.5, p.1722-1728, 1990.

KINDELAN, M. Dynamic modeling of greenhouse environment. Transactions od de ASAE, v.23, n.5, p.1232-1239, 1980

KITTAS, C.; BOULARD, T.; PAPADAKIS, G. Greenhouse ventilation rates through combined roof and side openings: an experimental study. Acta Horticulturae, n.443, p.31-38, 1997. 
KLAR, A.E. Irrigação: Freqüência e quantidade de aplicação. São Paulo: Nobel, 1991. 156p.

MARTINS, G. Uso de casa-de-vegetação com cobertura plástica na tomaticultura de verão. Jaboticabal, 1992. 65p. Tese (doutorado) Faculdade de Ciências Agrárias e Vetrinárias, Universidade Estadual Paulista "Júlio de Mesquita Filho".

MARTINS, R.M.; GONZALEZ, J.F. Evapotranspiração e respostas fisiológicas do feijão-vagem cultivado em substrato em estufa com sistema de ventilação/calefação. Revista Brasileira de Agrometeorologia, n.3, p.3137,1995

MILLS, P.J.W.; SMITH, I.E.; MARAIS, G. A greenhouse design for a cool subtropical climate with mild winters based on microclimatic measurementsof protected environments. Acta Horticulturae, n.281, p.8394, 1990.

MISTRIOTIS, A.; BOT, G.P.A.; PICUNO, P.; SCARASCIA-MUGNOZZA, G. Analysis of the efficiency of greenhouse ventilation using computational fluid dynamics. Agricultural and Forest Meteorology, v.85, n.3-4, p.217-228, 1997.

MONTERO, J.I. et al Climate under plastic in the Almeria area. Acta Horticulturae, n.170, p.227-234, 1985.

MONTERO, J.I.; MUÑOZ, P.; ANTÓN, A. Discharge coefficients of greenhouse windows with insect-proof screens. Acta Horticulturae, n.443, p.71-77, 1997.

NAVAS, L.M.; DE LA PLAZA, S.; DURÁN, J.M.; RETAMAL, N. Formulation and sensivity analysis of dynamic model of the mediterranean climate. Acta Horticulturae, n.456, p.305-312, 1998.

NELSON, P. V. Greenhouse operation and management. 4ed. New Jersey: Prentice Hall, 1991. 612p. 
NIELSEN, B.; MADSEN, H. Identification of a linear continuous time stochastic model of the heat dynamics of a greenhouse, Journal of Agricultural Engineering Research, n.71, p.249-256, 1998.

NIJSKENS, J.; DE HALLEUX, D.; DELTOUR, J. Sensitivity study of a greenhouse climate dynamic model. Bulletin des Recherches Agronomiques de Gembloux, v.26, n.3, p.389-410,1991.

NIJSKENS, J.; DELTOUR, J.; NISEN, A.; COUTISSE, S. Agronomic and radiometric characterization of greenhouse materials. Acta Horticulturae, n.148, p.663-673, 1984.

ODUM, E. P. Ecologia. Rio de Janeiro: Guanabara, 1983. 434p.

OLIVEIRA, C.R. Cultivo em ambiente protegido. Boletim Técnico CATI, n.232, p.1-31, abr 1997.

OLIVEIRA, M.R.V. DE O emprego de casas de vegetação no Brasil: Vantagens e desvantagens. Pesquisa Agropecuária Brasileira, v.30, n.8, p.10491060, ago.1995.

OMETTO, J. C. Bioclimatologia vegetal . São Paulo: Ceres, 1981. 440p.

PEREIRA, A.R.; VILLA NOVA, N.A.; SEDIYAMA, G.C. Evapo(transpi)ração. Piracicaba, FEALQ, 1997. 183p.

PESSOA, M.C.P.Y.; LUCHIARI JUNIOR, A.FERNANDES, E.N.; LIMA, M.A. de. Principais modelos e simuladores utilizados para análise de impactos ambientais das atividades agrícolas. Jaguariúna: Embrapa-CNPMA, 1997. 83p. (Embrapa-CNPMA. Documentos,8).

PEZZOPANE, J.E.M.; PEDRO JR, M.J.; ORTOLANI, A.A. Modificações microclimáticas provocadas por estufas com cobertura plástica. Bragantia, v.54, p.419-425, 1995a.

PEZZOPANE, J.E.M.; PEDRO JR, M.J.; ORTOLANi,A.A.; MEYER, N. Radiação líquida e temperatura de folha no interior de estufa com cobertura 
plástica, durante o período noturno. Revista Brasileira de Agrometeorologia, v.3, p.1-4, 1995b.

RAULT, P.A. A tunnel greenhouse adapted to the tropical lowland climate. Acta Horticulturae, n.281, p.95-103, 1987.

REIS, N.V.B. DOS Diferencial entre os parâmentros de temperaturas interna a externa de um estufa modelo teto-em-arco efeito guarda-chuva. In: Congresso Brasileiro de Agrometeorologia, 10, Piracicaba, 1997. Anais. Piracicaba: Sociedade Brasileira de Agrometeorologia, 1997. 465-467.

RICIERI, R.P.; ESCOBEDO, J.F. Radiação solar global e difusa em estufas túneis com cobertura de polietileno.. Energia na Agricultura, v.11, n.1, p.15-37, 1996.

SBITA, L.; BOULARD, T.; BAILLE, A.; ANNABI, M. A greenhouse climate model including the effects of ventilation and crop transpiration: Validation for the south Tunisia conditions. Acta Horticulturae, n.458, p.57-64, 1998.

SEGINER, 1. Alternative design formulae for the ventilation rate of greeenhouse. Journal of Agricultural Engineering Research, v.68, p.355-365, 1997.

SEGINER, I.; KANTZ, D.; PEIPER, U.; LEVAV, N. Transfer coefficients of several polyethylene grenhouse covers. Journal of Agricultural Engineering Research, v.39, p.19-37, 1988.

SENTELHAS, P.C.; VILLANOVA, N.A.; ANGELOCCI, L.R. Efeito de diferentes tipos de cobertura, em mini-estufas, na atenuação da radiação solar e da luminosidade. In: Congresso Brasileiro de Agrometeorologia, 10, Piracicaba, 1997. Anais. Piracicaba: Sociedade Brasileira de Agrometeorologia, 1997. 479-481.

SGANZERLA, EDILIO. Nova Agricultura: A fascinante arte de cultivar com os plásticos. 5ed. Guaiba: Agropecuária, 1995. 342p. 
SILVA, A.M.; ROSA, R. Radiative heat loss inside a greenhouse. Journal of Agricultural Engineering Research. V.37,p.155-162, 1987.

SIQUEIRA, C.M. A importância dos materiais plásticos na agricultura do Brasil e do mundo. In: AEASP. Programa de plasticultura para o Estado de São Paulo. Apostila. 1996. 109p.

SOUZA, J.L. DE; ESCOBEDO, J.F. Componentes do balanço de radiação sobre a cultura do feijão-vagem em ambiente natural e de estufa plástica. In: Congresso Brasileiro de Agrometeorologia, 9, Campina Grande, 1996. Anais. Campina Grande: Sociedade Brasileira de Agrometeorologia, 1996. 319-322.

STANGHELLINI, C.; DE JONG, T. A model of humidtiy and its applications in a greenhouse. Agricultural and Forest Meteorology, v.76, p.129-148, 1995.

TAKAKURA, T.; JORDAN, K.A; BOYD, L.L. Dynamic simulation fo plant growth and environment in the greenhouse. Transactions of de ASAE, v.14, n.5, p.964-971, 1971.

TAKAMI, S.; UCHIJIMA, Z. A model of the greenhouse environment as affected by the mass and energy exchange of a crop. Journal of Agricultural Meteorology, v. 33, n.3, p.117-127, 1977.

TARARA, J.M.; HAM, J.M. Measuring sensible heat flux in plastic mulch culture with aerodynamic conductance sensors. Agricultural and Forest Meteorology, v.95, p.1-13, 1999.

THORMLEY, J.H.M.; JOHNSON, I.R. Plant and crop modelling: A mathematical approach do plant and crop physiology. Oxford: Clarendon Press, 1990. 669.

YANG, X.; SHORT, T.H.; FOX, R.D.; BAUERLE, W.L. Dynamic modeling of the microcllimate of a greenhouse cucumber row-crop part II. Validation and 
Simulation. Transactions of the ASAE, v.33, n.5, p.1710-1716, set-nov. 1990.

WANG, S.; PIETERS, J.G.; DELTOUR, J. Studies on radiometric, thermal and climatic properties of a new greenhouse covering material. Acta Horticulturae, n.486, p.49-54, 1999.

ZAMIR, N.; MEDAN, G.; ARBEL, A.; LEVAV, N. The influence of climatic conditions on the heat losses from conventional and sloping greenhouses. Acta Horticulturae, n.148, p.319-328, 1984. 